\title{
Simulation of Temperature, Nutrients, Biochemical Oxygen Demand, and Dissolved Oxygen in the Cooper and Wando Rivers near Charleston, South Carolina, 1992-95
}

BY PAUL A. CONRADS and PAULEY A. SMITH

\section{U.S. GEOLOGICAL SURVEY}

Water-Resources Investigations Report 97-4151

Prepared in cooperation with the

SOUTH CAROLINA DEPARTMENT OF HEALTH AND ENVIRONMENTAL CONTROL, OFFICE OF OCEAN AND COASTAL RESOURCE MANAGEMENT, CHARLESTON HARBOR PROJECT

Columbia, South Carolina 1997

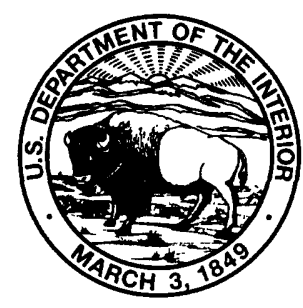




\title{
U.S. DEPARTMENT OF THE INTERIOR BRUCE BABBITT, Secretary
}

\author{
U.S. GEOLOGICAL SURVEY
}

Gordon P. Eaton, Director

The use of firm, trade, and brand names in this report is for identification purposes only and does not constitute endorsement by the U.S. Government.

For additional information write to:

District Chief

U.S. Geological Survey

Stephenson Center-Suite 129

720 Gracern Road

Columbia, South Carolina 29210-7651
Copies of this report can be purchased from:
U.S. Geological Survey
Branch of Information Services
Box 25286
Denver, Colorado 80225-0286 


\section{CONTENTS}

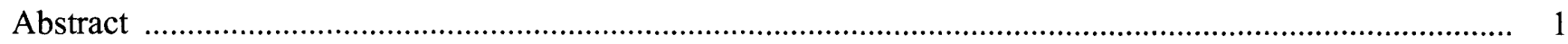

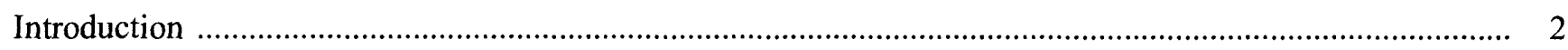

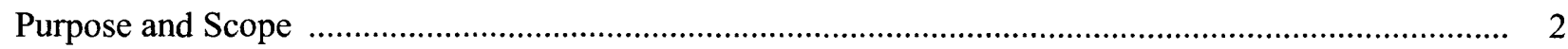

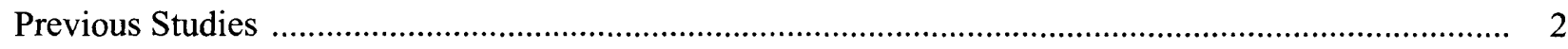

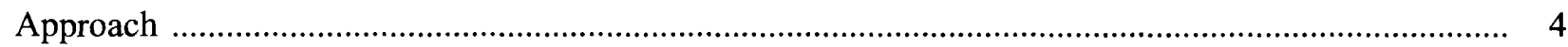

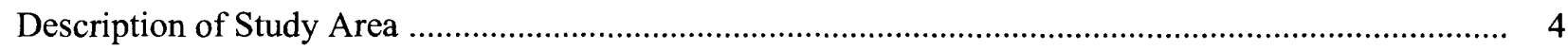

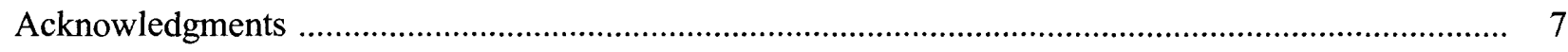

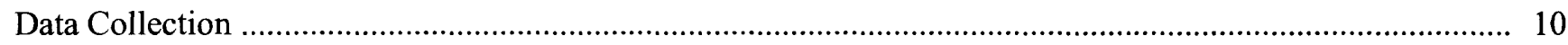

Continuous Water-Level and Water-Quality Data _........................................................................ 10

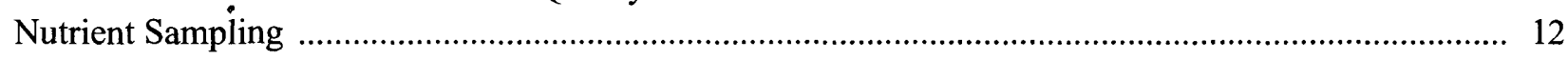

Simulation of Water Level, Streamflow, and Mass Transport ...................................................................... 14

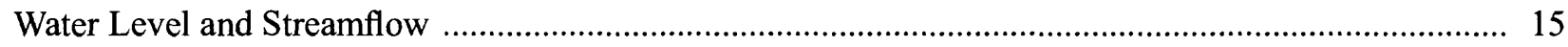

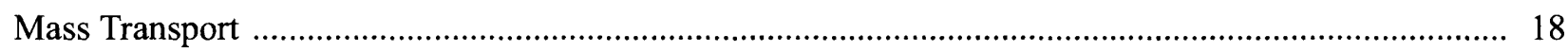

Calibration and Validation of Dynamic-Flow and Mass-Transport Models .............................................. 19

Simulation of Temperature, Nutrients, Biochemical Oxygen Demand, and Dissolved Oxygen ......................... 21

Calibration and Validation of Water Temperature …………................................................................ 23

Calibration and Validation of Nutrients, Biochemical Oxygen Demand, and Dissolved Oxygen ............. 26

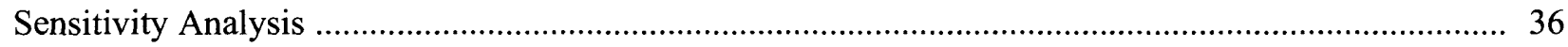

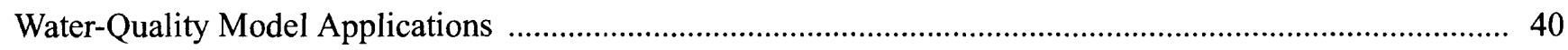

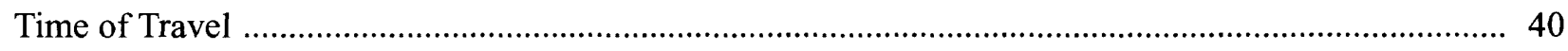

Flows from Pinopolis Dam ...................................................................................................... 43

Levels of Wastewater Treatment ..................................................................................................... 46

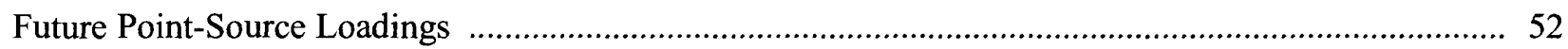

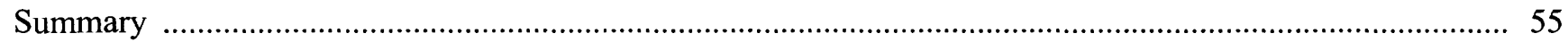

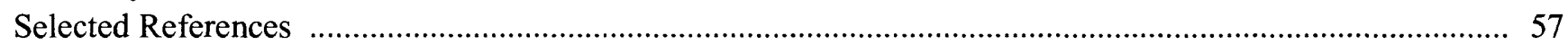


FIGURES

1-5. Maps showing:

1. Santee-Cooper River Basin, S.C.

2. Cooper and Wando Rivers, S.C

3. Location of National Pollutant Discharge Elimination System effluent dischargers on the Cooper and Wando Rivers and their tributaries, S.C.

4. Location of continuous-monitoring stations on the Cooper and Wando Rivers and their tributaries, S.C.

5. Location of nutrient-sampling stations on the Cooper and Wando Rivers and their tributaries, S.C

6-9. Diagrams showing:

6. Idealized BRANCH model schematization

7. BRANCH model schematization for the Cooper and Wando Rivers, S.C.

8. Branched Lagrangian Transport Model schematization for the Cooper and Wando Rivers, S.C. ......

9. Major constituent interactions in the QUAL2E model and Branched Lagrangian Transport Model

10-17. Graphs showing:

10. Simulated and measured water temperature used in the water-quality model calibration for two locations on the Cooper River and two locations on the Wando River, S.C., August 1-30, 1993

11. Simulated and measured water temperature used in the water-quality model validation for two locations on the Cooper River and two locations on the Wando River, S.C., April 8 - May 8, 1993

12. Simulated and measured constituent concentrations used in the water-quality model calibration for nine locations on the Cooper River, S.C., August 23-25, 1993

13. Simulated and measured constituent concentrations used in the water-quality model calibration for four locations on the Wando River and two locations on the Cooper River, S.C., August 23-25, 1993

14. Simulated and measured dissolved-oxygen concentrations used in the water-quality model calibration for three locations on the Cooper River and two locations on the Wando River, S.C., August 21-27, 1993

15. Simulated and measured constituent concentrations used in the water-quality model validation for nine locations on the Cooper River, S.C., May 4-5, 1993

16. Simulated and measured constituent concentrations used in the water-quality model validation for four locations on the Wando River and two locations on the Cooper River, S.C., May 4-5, 1993.

17. Simulated and measured dissolved-oxygen concentrations used in the water-quality model validation for three locations on the Cooper River and two locations on the Wando River, S.C., May 2-8, 1993

18. Map showing sites used for model scenarios on the Cooper and Wando Rivers, S.C. 
19-23. Graphs showing:

19. Flow hydrograph for Pinopolis Dam and tracer graphs for six sites on the Cooper River and one site on the Wando River, S.C., for August 1-30, 1993.

20. Longitudinal profiles of 24-hour mean and minimum dissolved-oxygen concentrations for three flow conditions on the Cooper River, S.C., August 27, 1993

21. Longitudinal profiles of 24-hour mean and minimum dissolved-oxygen concentrations for three point-source loading conditions on the Cooper River, S.C., August 27, 1993

22. Longitudinal profiles of 24-hour mean and minimum dissolved-oxygen concentrations for six point-source loading conditions on the Cooper River, S.C., August 27, 1993

23. Longitudinal profiles of 24-hour mean and minimum dissolved-oxygen concentrations for four projected point-source loading conditions on the Cooper River, S.C., August 27, 1993

1. National Pollutant Discharge Elimination System permit limits for wastewater-treatment facilities on the Cooper and Wando Rivers and their tributaries, S.C., as of May 6, 1997.

2. Continuous water-level and water-quality stations on the Cooper and Wando Rivers, S.C., and the parameters monitored

3. Nutrient sampling stations on the Cooper and Wando Rivers, S.C.

4. Boundary locations, data types, data sources, and data frequency for BRANCH model of the Cooper and Wando Rivers, S.C.

5. Rate constant coefficients, recommended values, and values used in the Branched Lagrangian Transport Model for the Cooper and Wando Rivers, S.C.

6. Percent of stations meeting calibration and validation criteria for seven constituents

7. Sensitivity indices for the Branched Lagrangian Transport Model inputs for the Cooper River downstream from Goose Creek, S.C.

8. Time of leading edge, time of peak concentration, and peak concentration for sites on the Cooper and Wando Rivers, S.C.

9. Simulated dissolved-oxygen concentrations for three flow conditions from Pinopolis Dam for 10 sites on the Cooper River, S.C.

10. Simulated dissolved-oxygen concentrations for three point-source loading conditions for 10 sites on the Cooper River, S.C.

11. Biochemical oxygen demand, ammonia-nitrogen, dissolved-oxygen concentration, and ultimate oxygen demand for four wastewater-treatment levels

12. Simulated dissolved-oxygen concentrations for six point-source loading conditions for 10 sites on the Cooper River, S.C.

13. Simulated dissolved-oxygen concentrations for four projected point-source loading conditions for 10 sites on the Cooper River, S.C. 
Abbreviations used in this report

$\begin{array}{ll}\text { BLTM } & \begin{array}{l}\text { Branched Lagrangian Transport Model } \\ \text { BOD }\end{array} \\ \text { bOD }_{5} & \text { 5-day biochemical oxygen demand } \\ \text { CBOD }_{\mathrm{u}} & \text { ultimate carbonaceous biochemical oxygen demand } \\ \text { CBOD }_{30} & \text { 30-day carbonaceous biochemical oxygen demand } \\ \text { DO } & \text { dissolved oxygen } \\ \text { FW } & \text { freshwater } \\ \text { NPDES } & \text { National Pollutant Discharge Elimination System } \\ \text { ppt } & \text { parts per thousand }\end{array}$

SA tidal saltwaters suitable for primary and secondary contact recreation; daily average dissolved-oxygen concentration not less than $5.0 \mathrm{mg} / \mathrm{L}$ (milligrams per liter) with a low of $4.0 \mathrm{mg} / \mathrm{L}$.

SB

tidal saltwaters suitable for primary and secondary contact recreation; dissolvedoxygen concentration not less than $4.0 \mathrm{mg} / \mathrm{L}$.

SCDHEC South Carolina Department of Health and Environmental Control

SFH shellfish harvestable tidal saltwaters

UOD ultimate oxygen demand

USCOE U.S. Army Corps of Engineers

USEPA U.S. Environmental Protection Agency

USGS U.S. Geological Survey

WASP4 Water Analysis Simulation Program--version 4.0

Sea level: In this report, "sea level" refers to the National Geodetic Vertical Datum of 1929--a geodetic datum derived from a general adjustment of the first-order level nets of the United States and Canada, formerly called Sea Level Datum of 1929. 


\title{
Simulation of Temperature, Nutrients, Biochemical
}

\section{Oxygen Demand, and Dissolved Oxygen in the Cooper and Wando Rivers near Charleston, South Carolina, 1992-95}

\author{
By Paul A. Conrads ${ }^{1}$ and Pauley A. Smith ${ }^{2}$
}

\section{Abstract}

Longitudinal dissolved-oxygen profiles of the Cooper River for various hydrologic and pointsource loading conditions were determined using results from water-quality simulations by the Branched Lagrangian Transport Model. The study area included the Cooper and Wando Rivers, near Charleston, S.C. Hydrodynamic data for the Branched Lagrangian Transport Model were simulated using the U.S. Geological Survey

BRANCH one-dimensional dynamic-flow model. Data used to calibrate the Branched Lagrangian Transport Model included: nutrient and biochemical oxygen demand concentrations collected over five tidal cycles during two sampling surveys at ten sites on the Cooper River and four sites on the Wando River; continuous water temperature at two locations on the Cooper River and two locations on the Wando River; and continuous dissolved-oxygen concentrations at three locations on the Cooper River and two locations on the Wando River. A sensitivity analysis of the simulated dissolved-oxygen concentrations to model coefficients and data inputs was done. Of the model coefficients, the simulated dissolved-oxygen concentrations were most sensitive to reaeration rate. Of the data inputs to the model, the simulated

\footnotetext{
${ }^{1}$ U.S. Geological Survey

${ }^{2}$ South Carolina Department of Health and Environmental Control
}

dissolved-oxygen concentrations were most sensitive to the equilibrium temperature.

Various water-resource management scenarios were simulated with the model using the calibration period of August 1-30, 1993. The time of travel of the system was simulated by injecting a conservative tracer at the upstream boundary on the Cooper River. The leading edge of the tracer reached the downstream boundary of the model 10 days after the beginning of the simulation and the peak concentration reached the boundary in 18 days. Flows from the Jefferies Hydroelectric Plant at Pinopolis Dam were increased and decreased by 50 percent to evaluate the effect on the dissolved-oxygen concentrations of the Cooper River. Decreasing the flows by 50 percent (from a 30-day average of 4,032 to 2,016 cubic feet per second) decreased the 24-hour mean dissolved-oxygen concentrations by 8.0 percent or less at 10 fixed sites on the Cooper River, as compared to the 24-hour mean dissolved-oxygen concentrations using the actual flows from the dam. Increasing the flows by 50 percent (from a 30-day average of 4,032 to 6,048 cubic feet per second) increased the 24-hour mean dissolved-oxygen concentrations by 4.0 percent or less at 8 of the 10 sites and decreased by 4.6 percent or less at the lower two sites.

Various point-source loading conditions to the system were simulated and evaluated. Setting all the point-source loadings to the fully permitted levels decreased the 24-hour mean 
dissolved-oxygen concentrations from the noeffluent loading condition by 35 percent or less. Setting all the point-source loadings to minimum wastewater-treatment concentrations of secondary treatment ( 20 milligrams per liter of ammonia and 30 milligrams per liter of biochemical oxygen demand) decreased the total loading to the system by 65 percent and decreased the 24 -hour mean dissolved-oxygen concentrations from the no-effluent loading condition by 16 percent or less. Projected point-source loadings for the years $2000,2005,2010$, and 2015 were input into the water-quality model. Decreases over the 1997 fully permitted levels are projected for years 2000 , 2005,2010 , and 2015 with decreases of total loading to the system of $43,40,32$, and 30 percent, respectively. The projected decrease in the 24hour dissolved-oxygen concentrations for the loading condition of the year 2015 over the noeffluent loading condition is 32 percent or less as compared to 35 percent or less for the fully permitted 1997 condition.

\section{INTRODUCTION}

The Cooper and Wando Rivers are tidally affected rivers that are major tributaries to the Charleston Harbor, which is located near the middle of the South Carolina coast (fig. 1). The water quality of Charleston Harbor and its tributaries, the Cooper, Wando, and Ashley Rivers, is increasingly being stressed by point-source (municipal and industrial wastewater effluent) and nonpoint-source pollutant loadings.

As the Charleston area continues to grow, demands on its water resources increasingly conflict. The Harbor and its tributaries function as an important economic, natural habitat, and aesthetic resource. The Charleston Harbor is the second largest container port on the East Coast, with the shipping traffic passing through the Harbor to terminal ports located on the Cooper and Wando Rivers. The tributary rivers and tidal creeks are also critical fisheries habitats. In addition, the recreational use of these coastal waters is essential to the growing tourism and retirement communities of the Charleston area and the South Carolina coast.
In May 1992, the U.S. Geological Survey (USGS), in cooperation with the South Carolina Department of Health and Environmental Control (SCDHEC), Office of Ocean and Coastal Resource Management, Charleston Harbor Project, initiated a study to develop a computer simulation model of water quality of the Cooper and Wando Rivers. The simulation model of the two-river system will allow State and local water-resource managers and regulators to assess the effects of regulatory decisions on the water quality in the Cooper and Wando Rivers.

\section{Purpose and Scope}

The purpose of this report is to present the results of the application of the one-dimensional, dynamic water-quality model BLTM (Branched Lagrangian Transport Model) to the Cooper and Wando Rivers. The modeling effort was undertaken in two phases. The results of these modeling studies are presented in two reports: phase one, Conrads and Smith (1996), and phase two, this report. The scope of the second phase was to calibrate and validate the water-quality model (BLTM) to simulate the fate and transport of non-conservative constituents such as nutrients, biochemical oxygen demand (BOD), and dissolved oxygen. The scope of the first phase was to calibrate and validate the dynamic-flow model (BRANCH) and mass-transport model (BLTM) to simulate the movement of a conservative constituent (salinity) in the system.

\section{Previous Studies}

There have been numerous environmental, hydrologic, sedimentation, and modeling studies of Charleston Harbor and the Cooper and Wando Rivers (Chestnut, 1989; Kjerfve, 1976; Patterson, 1983; Teeter, 1989; Teeter and Pankow, 1989; Van Dolah and others, 1990). This investigation builds on previous studies by the SCDHEC, the USGS, and the University of South Carolina School of Public Health. The SCDHEC applied a U.S. Environmental Protection Agency (USEPA) water-quality model, the Water Analysis and Simulation Program-4 (WASP4), to the Cooper and Wando Rivers (Ambrose and others, 1988; South Carolina Department of Health and Environmental Control, 1991a). The USGS previously applied the BRANCH model to the Cooper River and Bushy Park Reservoir to determine retention times in the reservoir (Bower 


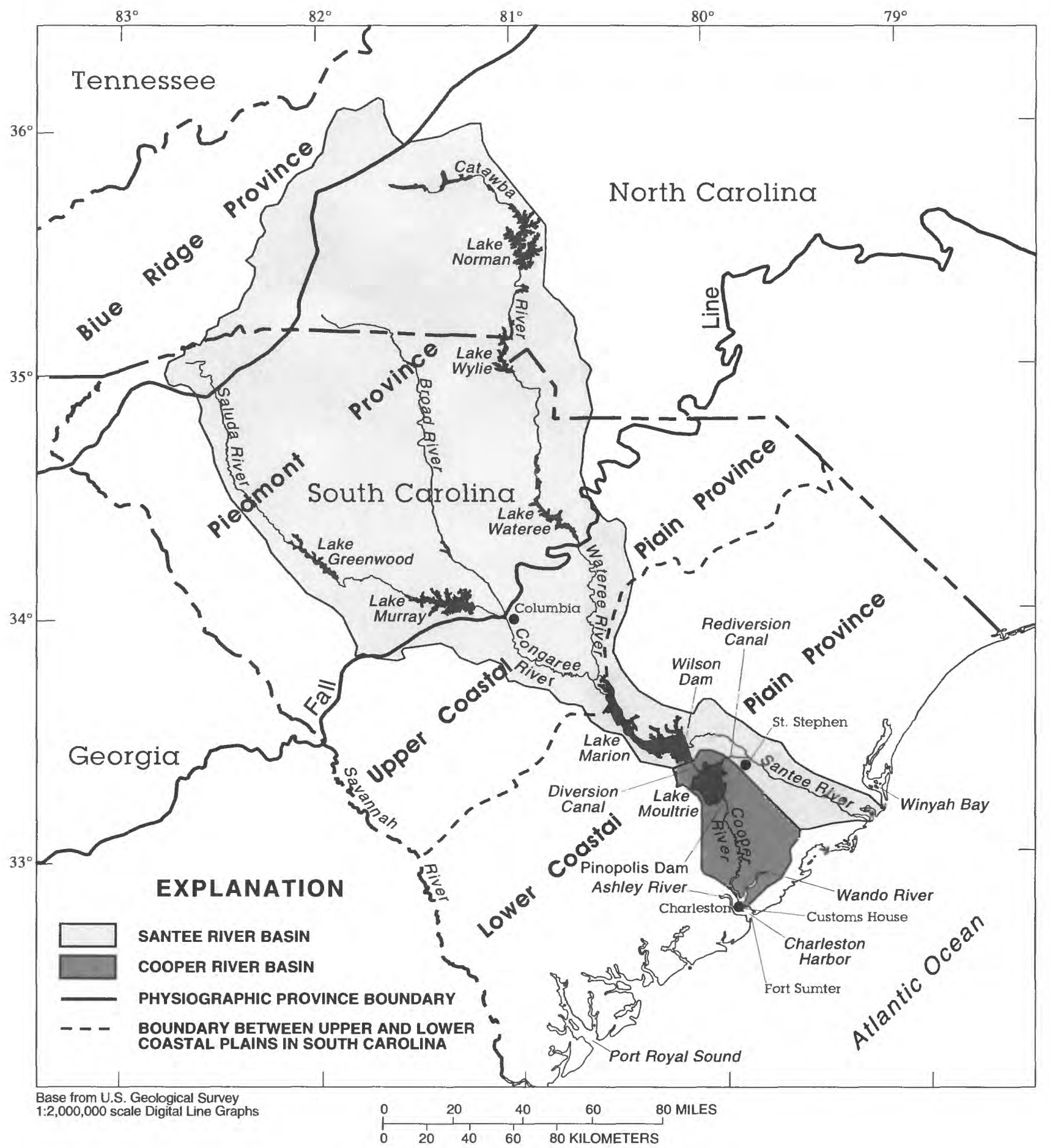

Figure 1. Santee-Cooper River Basin, S.C. 
and others, 1993). The University of South Carolina School of Public Health applied the BRANCH model to Goose Creek in a study of nutrient fluxes of tidal marshes (McKellar and others, 1995). The current (1997) effluent-discharge limits for the Cooper River are based on results from simulations using WASP4.

\section{Approach}

Dissolved oxygen is one of the primary waterquality constituents used as an indicator of the ecological health of a waterbody. The ability to simulate the concentration of dissolved oxygen is necessary for water-resource managers to assess the effects of pointand nonpoint-source pollution on a waterbody. The models described in this report principally will be used by water-resource managers to determine the assimilative capacity of the Cooper and Wando Rivers. The capacity of a stream to assimilate oxygen-demanding substances is a function of streamflow, water temperature, velocity, depth, wind speed, and channel configuration. In water-resource management, this capacity is expressed in terms of pounds per day of ultimate oxygen demand (UOD) that can be assimilated during a particular set of hydrologic conditions without violating the State water-quality standards for dissolved oxygen.

In discussions with the cooperating agency concerning the study plan, it was decided that the models applied to the system should be readily available and usable by water-resource managers. A one-dimensional dynamic-flow model (BRANCH) and a onedimensional dynamic-transport and water-quality model (BLTM) were applied to the two-river system. The BRANCH model was used to generate the required hydraulic data for input into the BLTM, which was used to simulate the transport of conservative and non-conservative constituents.

The general approach to applying the models was to calibrate and validate the BRANCH and BLTM models by first simulating the movement of a conservative constituent. Concentration of a conservative constituent is not affected by biological degradation or chemical reaction, but is affected by dilution in response to changing streamflow conditions. Salinity, a conservative constituent, is an effective natural tracer for calibrating and validating mass transport. After successfully calibrating and validating the model for the mass transport of a conservative constituent (salinity), non-conservative constituents (nutrients and dis- solved oxygen) can be simulated. Concentration of a non-conservative constituent may be affected by biological degradation or chemical reaction, in addition to dilution in response to changing streamflow conditions.

Several types of data were required for application of the models. A large data-collection effort was completed during the 1992-95 water years (Conrads and others, 1997). Data that were required to calibrate and validate the hydraulic, transport, and water-quality models included (1) continuous water level or streamflow, specific conductance, water temperature, and dissolved-oxygen concentrations at the upstream and downstream boundaries and at selected interior locations, (2) tidal-cycle measurements of streamflow and nutrient concentrations at boundaries and selected interior locations, (3) channel geometry, and (4) municipal and industrial discharge flow rates as well as selected constituent concentrations in those effluents.

The area of major water-quality concern is located in the lower reaches of the Cooper River in the vicinity of Goose Creek (fig. 2) (Davis and others, 1990, South Carolina Department of Health and Environmental Control, 1991a). Therefore, emphasis was placed on the accuracy of the calibration and validation processes for the area downstream of the confluence of the West and East Branches of the Cooper River and below S.C. Highway 41 on the Wando River. A successfully calibrated water-quality model of the tworiver system should yield nutrient and dissolved-oxygen concentrations that agree favorably with field measurements of those parameters. However, there are inherent limitations in the application of one-dimensional models to a highly complex, three-dimensional environmental system. Emphasis during the calibration and validation processes was placed on achieving satisfactory simulations of dissolved oxygen and BOD, because the water-quality model will be used to assist in the determination of wasteload allocations and total maximum daily load (TMDL) determinations that are based on NPDES (National Pollutant Discharge Elimination System) permit limitations for these constituents.

\section{Description of Study Area}

The Cooper and Wando Rivers are located in the lower Coastal Plain physiographic province in the lower part of the Santee-Cooper River Basin (fig. 1). This basin covers $21,700 \mathrm{mi}^{2}$ (square 


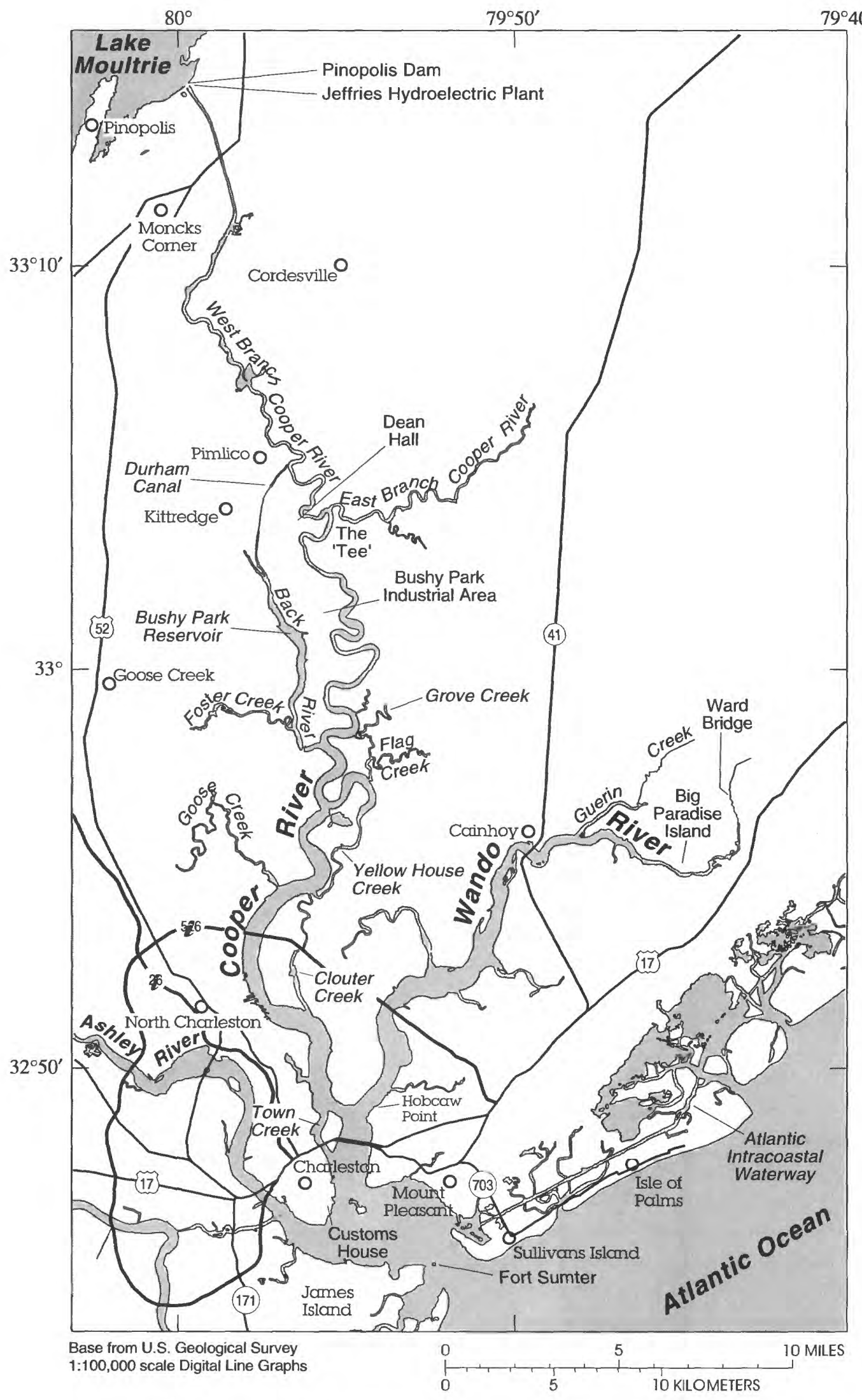

Figure 2. Cooper and Wando Rivers, S.C. 
miles) and is the second largest drainage basin on the East Coast. The Charleston Harbor experiences semidiurnal tides with mean- and spring-tidal ranges of 5.09 and $5.90 \mathrm{ft}$ (feet), respectively, at the harbor entrance at Fort Sumter (National Oceanic and Atmospheric Administration, 1995). The Cooper and Wando Rivers drain $830.5 \mathrm{mi}^{2}$ that consist of 51.7 percent forest, 15.0 percent wetlands, 9.4 percent urban area, 16.4 percent water, 4.3 percent scrub and scrubland, 2.7 percent agricultural land, and 0.5 percent barren land (South Carolina Land Resources Conservation Commission, 1990; South Carolina Department of Health and Environmental Control, 1996).

The Santee and Cooper Rivers have long histories of anthropogenic changes (Kjerfve, 1976). Rice plantations, with large diked fields along the banks of the Cooper and Wando Rivers, flourished in the 18th and 19 th centuries. With the advent of mechanized rice harvesting, rice production diminished because heavy machinery was unsuitable for the clayey soils of the area. Because of the increased demand for electric power in the 1930's, the Santee-Cooper Project created two freshwater lakes by diverting flows from the Santee River and used the naturally high topographic relief adjacent to the Cooper River to generate hydroelectric power. The project was completed in 1941 by the construction of Wilson Dam across the Santee River that formed Lake Marion, and Pinopolis Dam near the headwaters of the West Branch Cooper River that formed Lake Moultrie (figs. 1, 2). A 4- mi (mile) diversion canal was built to connect the two lakes. The Jefferies Hydroelectric Plant was built at Pinopolis Dam. The water-surface elevation difference between Lake Moultrie and the Cooper River is approximately $70 \mathrm{ft}$, as compared to an 18- $\mathrm{ft}$ difference between the watersurface elevations of Lake Marion and the Santee River (Kjerfve, 1976).

The diverted flows from the Santee River through Pinopolis Dam to the West Branch Cooper River had pronounced effects on the Cooper River and the Charleston Harbor (Kjerfve, 1976). The Cooper River was transformed from a tidal slough with a mean annual downstream flow of $71 \mathrm{ft}^{3 /} \mathrm{s}$ (cubic feet per second) to a riverine system with a mean annual streamflow of $15,600 \mathrm{ft}^{3} / \mathrm{s}$ (U.S. Army Corps of Engineers, 1966). The diversion of water transformed Charleston Harbor from a well-mixed estuary to a partially mixed estuary and an effective sediment trap (Patterson, 1983). After diversion, mean salinity values in
Charleston Harbor decreased from 31 to $16 \mathrm{ppt}$ (parts per thousand) (Kjerfve and Magill, 1990).

In 1954, the Bushy Park industrial area was established along the east bank of the Back River and the west bank of the Cooper River. To provide water to the industrial users, a freshwater reservoir was constructed by damming the Back River at the lower end near the confluence with the Cooper River. Durham Canal was constructed as a conduit between the upper end of the reservoir and the freshwater part of the Cooper River.

In 1985, the USCOE (U.S. Army Corps of Engineers) rediverted flows from Lake Moultrie back to the Santee River to alleviate a severe sedimentation problem in Charleston Harbor created by the diversion of freshwater flows. The diversion was accomplished by building an 11-mi rediversion canal from Lake Moultrie to the Santee River. A hydroelectric plant was built at St. Stephen to help offset lost power generation from the Jefferies Hydroelectric Plant (figs. 1, 2). The approximate difference in the water levels between the rediversion canal and St. Stephen tailrace is $46 \mathrm{ft}$ (Kjerfve, 1976). After the rediversion project, the flows to the Cooper River were reduced from the annual mean flow of $15,600 \mathrm{ft}^{3} / \mathrm{s}$ to a weekly mean flow of $3,000 \mathrm{ft}^{3} / \mathrm{s}$, a level that would alleviate sedimentation in the harbor while ensuring an adequate freshwater source to the Bushy Park Reservoir (fig. 2) at the mouth of the Durham Canal (South Carolina Water Resources Commission, 1979).

The Cooper River is formed by the confluence of the West and East Branches of the Cooper River at an area referred to as the "Tee" (fig. 2). The West Branch Cooper River flows $18 \mathrm{mi}$ from the tailrace of Pinopolis Dam to the confluence with the East Branch Cooper River at the Tee. This reach is a meandering natural channel bordered by extensive tidal marshes and old rice fields in varying states of disrepair. This area contains large amounts of poorly defined overbank storage and unmeasurable flows through broken levees between the main channel and the rice fields. The East Branch Cooper River is a tidal slough throughout its 8mi reach. On the Cooper River, from the Tee to Flag Creek, industries are located along the west bank of the river and the east bank is dominated by extensive Spartina alterniflora salt marshes. Downstream of Flag Creek, the main channel has been dredged to a depth of $42 \mathrm{ft}$ by the USCOE for navigational purposes (National Oceanic and Atmospheric Administration, 1992). Industries dominate the west bank of the river 
and the east bank contains numerous dredge-material disposal areas.

The Cooper River is tidally affected throughout its entire reach, and has mean- and spring-tidal ranges of 5.27 and $6.11 \mathrm{ft}$, respectively, at the Customs House on the lower Cooper River, and mean- and spring-tidal ranges of 1.70 and $1.97 \mathrm{ft}$, respectively, at Pimlico on the West Branch Cooper River (National Oceanic and Atmospheric Administration, 1995). Saltwater in the Cooper River extends from the Harbor upstream to several miles below the Tee. The annual mean flows from Pinopolis Dam were 5,810; 5,740; and 5,270 $\mathrm{ft}^{3 / \mathrm{s}}$ in 1992, 1993, and 1994, respectively (Cooney and others, 1996).

The SCDHEC has classified the Cooper River as SB (tidal saltwater) from the confluence of the Cooper and Wando Rivers to a point approximately $50 \mathrm{mi}$ upstream near the Tee, and has set a dissolved-oxygen standard for this reach of not less than $4.0 \mathrm{mg} / \mathrm{L}$ (milligrams per liter). From the Tee upstream to U.S. Highway 52, the Cooper River is classified as FW

(freshwater) and has a daily average dissolved-oxygen standard of not less than $5.0 \mathrm{mg} / \mathrm{L}$ with a minimum of $4.0 \mathrm{mg} / \mathrm{L}$ (South Carolina Department of Health and Environmental Control, 1993).

The Wando River is a tidal slough that tapers from a width of about $2,600 \mathrm{ft}$ at its mouth to a narrow tidal creek in the vicinity of Ward Bridge approximately $21 \mathrm{mi}$ upstream from the confluence with the Cooper River (fig. 2). Saltwater extends throughout the Wando River. The banks of the river are dominated by extensive Spartina alterniflora salt marshes. The tidal ranges in the Wando River amplify as they progress upstream. Mean- and spring-tidal ranges at Hobcaw Point, near the confluence with the Cooper River, are 5.44 and $6.31 \mathrm{ft}$, respectively. As the tide progresses upstream, the mean- and spring-tidal ranges increase to 6.54 and $7.59 \mathrm{ft}$, respectively, at Big Paradise Island (National Oceanic and Atmospheric Administration, 1995). The Wando River is relatively undeveloped. A shipyard is located near the town of Cainhoy and a shipping terminal is located in the lower part of the river. However, residential areas are beginning to develop along the east bank.

The Wando River is classified as SA (tidal saltwater) by SCDHEC from its confluence with Cooper River to a point approximately $2.5 \mathrm{mi}$ upstream near the Interstate 526 bridge. Above this point to the headwaters, the Wando River is classified as SFH (Shellfish Harvesting Waters). The dissolved-oxygen standard for the entire Wando River is a daily average of not less than $5.0 \mathrm{mg} / \mathrm{L}$ with a low of $4.0 \mathrm{mg} / \mathrm{L}$ (South Carolina Department of Health and Environmental Control, 1993).

Currently (1997), there are 24 industries and 10 municipalities (fig. 3, table 1) under the NPDES that are permitted to discharge to the Cooper River or its major tributaries (N.R. Sullins, South Carolina Department of Health and Environmental Control, oral and electronic communications, 1997). Eight of the discharges (four industrial and four municipal) are major facilities that have discharge flows in excess of 1.0 $\mathrm{Mgal} / \mathrm{d}$ (million gallons per day). Twenty-seven of the dischargers, including seven of the major facilities, are located below the Tee. Two NPDES permittees (one industrial and one municipal) discharge into the Wando River or its tributaries, each having discharges of less than $1.0 \mathrm{Mgal} / \mathrm{d}$. The NPDES permit limits for wastewater-treatment facilities (and two that were in effect in 1993) are listed in table 1 and the locations are shown in fig. 3.

\section{Acknowledgments}

A study of this complexity required interagency cooperation as well as individual contributions. The authors would like to thank J. Heyward Robinson, Director of the Charleston Harbor Project, for providing the support and coordination of the concerned local interests in the Charleston area; David Chestnut, the late Russell W. Sherer, Nancy Sullins, and Edward "Butch" Younginer of the SCDHEC for their assistance in field sampling, laboratory analysis, and technical support; the permitted dischargers for providing effluent data during the synoptic sampling surveys; the South Carolina Public Service Authority for streamflow data from Pinopolis Dam; and the members of the Advisory Board to the Water-Quality Modeling Project of the Charleston Harbor Project for their annual review of the study. Board members include Ralph Cheng of the USGS, David Correl of the Smithsonian Institute, and James Greenfield of USEPA. 


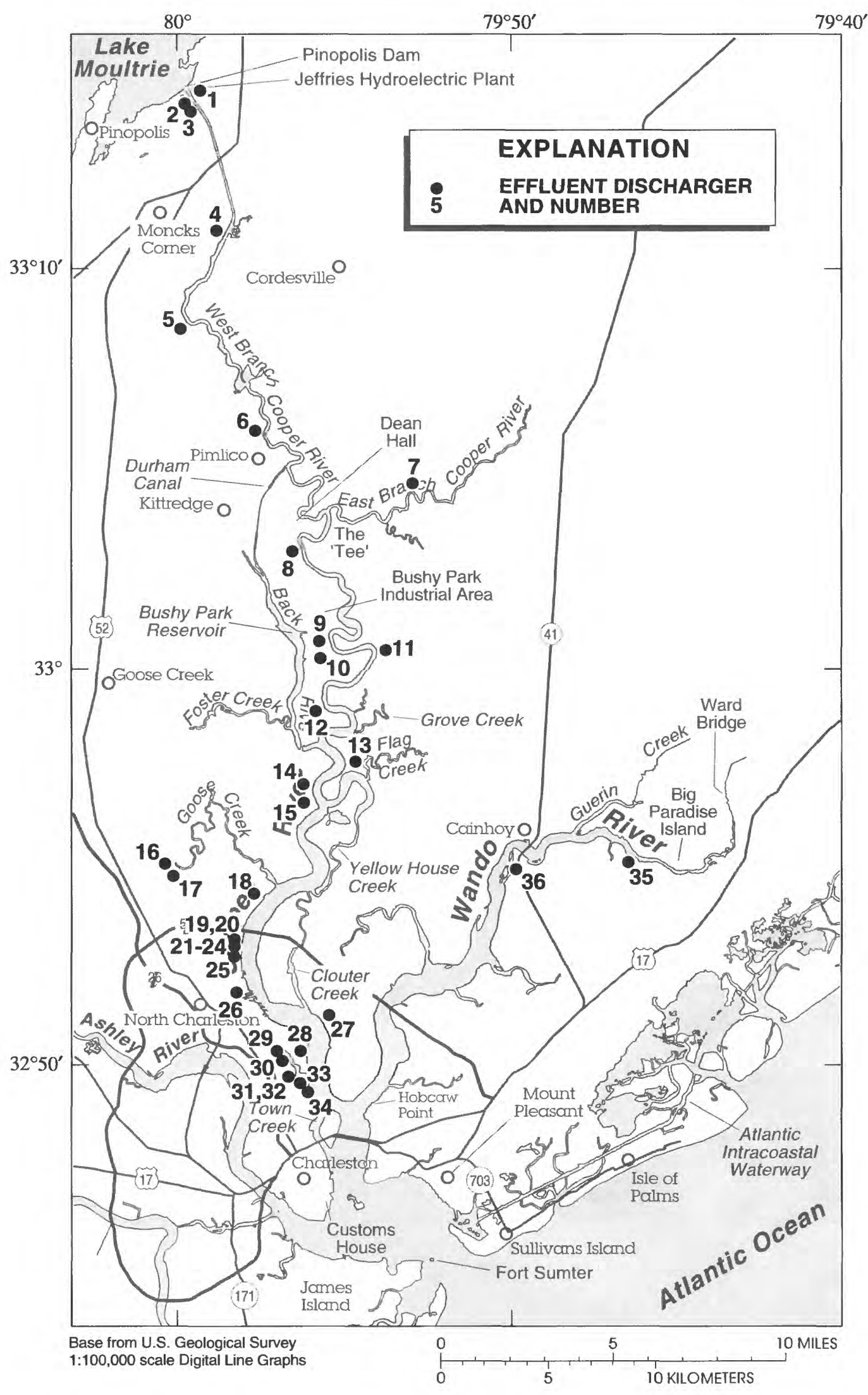

Figure 3. Location of National Pollutant Discharge Elimination System effluent dischargers on the Cooper and Wando Rivers and their tributaries, S.C. 
Table 1. National Pollutant Discharge Elimination System permit limits for wastewater-treatment facilities on the Cooper and Wando Rivers and their tributaries, South Carolina as of May 6, 1997

[Mgal/d, million gallons per day; $\mathrm{BOD}_{5}$, 5-day biochemical oxygen demand; $\mathrm{mg} / \mathrm{L}$, milligrams per liter; $\mathrm{NH}_{3}-\mathrm{N}$, ammonia-nitrogen; DO, dissolved oxygen; UOD, ultimate oxygen demand; lb/d, pounds per day; [20], not limited on permit-value used in UOD calculation; --, not applicable; *, pounds per day; M/R, monitor and report; UT, unnamed tributary]

\begin{tabular}{|c|c|c|c|c|c|c|}
\hline $\begin{array}{c}\text { Site } \\
\text { (fig. 3) }\end{array}$ & Receiving waters & $\begin{array}{l}\text { Effluent } \\
\text { (Mgal/d) }\end{array}$ & $\begin{array}{l}\text { BOD5 } \\
\text { (mg/L) }\end{array}$ & $\begin{array}{l}\text { NH3-N } \\
\text { (mg/L) }\end{array}$ & $\begin{array}{c}\mathrm{DO} \\
(\mathrm{mg} / \mathrm{L})\end{array}$ & $\begin{array}{l}\text { UOD } \\
\text { (lb/d) }\end{array}$ \\
\hline 1 & Tailrace Canal & 0.006 & 30.0 & {$[20.0]$} & -- & 6.8 \\
\hline 2 & Tailrace Canal & .192 & *22.5 & - & 1.0 & 33.8 \\
\hline 3 & Tailrace Canal & $\mathrm{M} / \mathrm{R}$ & - & -- & -- & - \\
\hline 4 & West Branch Cooper River & 1.6 & $* 400$ & {$[20.0]$} & 2.0 & 1,820 \\
\hline 5 & West Branch Cooper River & .35 & 30.0 & {$[20.0]$} & 2.0 & 398 \\
\hline${ }^{1} 6$ & West Branch Cooper River & .13 & *325 & {$[20.0]$} & 1.0 & 152 \\
\hline 7 & East Branch Cooper River & .012 & 30 & {$[20.0]$} & 1.0 & 13.7 \\
\hline 8 & Cooper River & 1.322 & *214 & - & 1.0 & 642 \\
\hline 9 & Cooper River & $\mathrm{M} / \mathrm{R}$ & -- & -- & -- & -- \\
\hline 10 & Cooper River & .015 & 30.0 & {$[20.0]$} & 1.0 & 17.1 \\
\hline 11 & Cooper River & .08 & 5.0 & -- & 1.0 & 5.0 \\
\hline${ }^{2} 12$ & Cooper River & 4.889 & $* 1,420$ & $\mathrm{M} / \mathrm{R}$ & 1.0 & 5,450 \\
\hline 13 & Cooper River & 2.33 & $* 541$ & -- & 1.0 & 1,620 \\
\hline 14 & Cooper River & 15.0 & $* 3,753$ & $* 2,502$ & 3.0 & 18,900 \\
\hline 15 & Cooper River & $\mathrm{M} / \mathrm{R}$ & - & -- & - & - \\
\hline 16 & Goose Creek & $\mathrm{M} / \mathrm{R}$ & -- & -- & -- & - \\
\hline 17 & Goose Creek & 1.3 & 30.0 & 16.4 & 2.0 & 1,300 \\
\hline 18 & Cooper River & 22.9 & $* 14,655$ & - & -- & 58,600 \\
\hline 19 & UT to Filbin Creek & $\mathrm{M} / \mathrm{R}$ & -- & -- & -- & - \\
\hline 20 & Cooper River & .233 & 10.0 & -- & - & 27.9 \\
\hline 21 & Cooper River & .053 & 10.0 & - & -- & 6.6 \\
\hline 22 & Cooper River & $\mathrm{M} / \mathrm{R}$ & -- & -- & -- & - \\
\hline 23 & Cooper River & $\mathrm{M} / \mathrm{R}$ & -- & -- & - & - \\
\hline 24 & Cooper River & .19 & 30.0 & {$[20.0]$} & 1.0 & 216 \\
\hline 25 & Cooper River & .081 & 30.0 & {$[20.0]$} & -- & 92.1 \\
\hline 26 & Cooper River & .056 & 30.0 & {$[20.0]$} & 1.0 & 63.7 \\
\hline 27 & UT to Cooper River & .25 & 5.0 & 1.0 & 5.0 & 25.2 \\
\hline 28 & Cooper River & $\mathrm{M} / \mathrm{R}$ & -- & -- & -- & -- \\
\hline
\end{tabular}


Table 1. National Pollutant Discharge Elimination System permit limits for wastewater-treatment facilities on the Cooper and Wando Rivers and their tributaries, South Carolina as of May 6, 1997--Continued

[Mgal/d, million gallons per day; $\mathrm{BOD}_{5}, 5$-day biochemical oxygen demand; $\mathrm{mg} / \mathrm{L}$, milligrams per liter; $\mathrm{NH}_{3}-\mathrm{N}$, ammonia-nitrogen; DO, dissolved oxygen; UOD, ultimate oxygen demand; Ib/d, pounds per day; [20], not limited on permit - value used in UOD calculation; --, not applicable; *, pounds per day; M/R, monitor and report; UT, unnamed tributary]

\begin{tabular}{clccccc}
\hline $\begin{array}{c}\text { Site } \\
\text { (fig. 3) }\end{array}$ & \multicolumn{1}{c}{ Receiving waters } & $\begin{array}{c}\text { Effluent } \\
\text { (Mgal/d) }\end{array}$ & $\begin{array}{c}\text { BOD5 } \\
\text { (mg/L) }\end{array}$ & $\begin{array}{c}\text { NH3-N } \\
\text { (mg/L) }\end{array}$ & $\begin{array}{c}\text { DO } \\
\text { (mg/L) }\end{array}$ & $\begin{array}{c}\text { UOD } \\
\text { (lb/d) }\end{array}$ \\
\hline 29 & Shipyard Creek & 0.013 & 30.0 & - & 1.0 & 4.9 \\
30 & Shipyard Creek & M/R & - & - & - & - \\
31 & Shipyard Creek & M/R & - & -- & -- & -- \\
332 & Shipyard Creek & M/R & 30.0 & - & -- & - \\
33 & Shipyard Creek & M/R & -- & -- & -- & - \\
34 & Cooper River & 27.0 & $* 6,755$ & $* 31,075$ & 1.0 & 152,000 \\
435 & Alston Creek & .01 & 30.0 & {$[20.0]$} & 2.0 & 11.4 \\
36 & Wando River & .025 & 30.0 & {$[20.0]$} & 1.0 & 28.4 \\
\hline Total UOD for the Cooper-Wando Rivers system & & & & & 242,000 \\
\hline
\end{tabular}

\footnotetext{
${ }^{1}$ Permit inactive as of March 1, 1995. Not used in total UOD computation.

${ }^{2}$ Permit based on UOD.

${ }^{3}$ Not used in total UOD computation.

${ }^{4}$ Permit inactive as of November 3, 1994. Not used in total UOD computation.
}

\section{DATA COLLECTION}

Data collected to calibrate and validate the waterquality model included (1) continuous water level, specific conductance, water temperature, and dissolvedoxygen concentrations at 14 gaging stations, (2) tidalcycle nutrient sampling at 14 locations, (3) meteorological data, and (4) effluent concentrations and discharge data from the hydroelectric, municipal, and industrial facilities. Permitted wastewater-discharge data from treatment plants and monthly water-quality monitoring data were provided by the SCDHEC. Additional data were collected for the calibration and validation of the flow and mass-transport model (Conrads and Smith, 1996; Conrads and others, 1997).

\section{Continuous Water-Level and Water- Quality Data}

Water level, specific conductance, water temperature, and dissolved oxygen data were recorded at 15-minute intervals by data-collection platforms (fig. 4, table 2). Water-level gages used a float-counterweight system in stilling wells that were interfaced to shaft encoders. The datum for each gaging station was determined by surveys from established benchmarks. Water-quality probes were interfaced to USGS waterquality minimonitors. Water-quality probes were set at the mid-depth of the water column at most stations. To monitor possible stratification in the lower reaches of the Cooper and Wando Rivers, five stations were instrumented with probes near the top and near the bottom of the water column (table 2 ). Salinity concentrations were calculated from specific conductance data using the algorithms described by Miller and others (1988). 


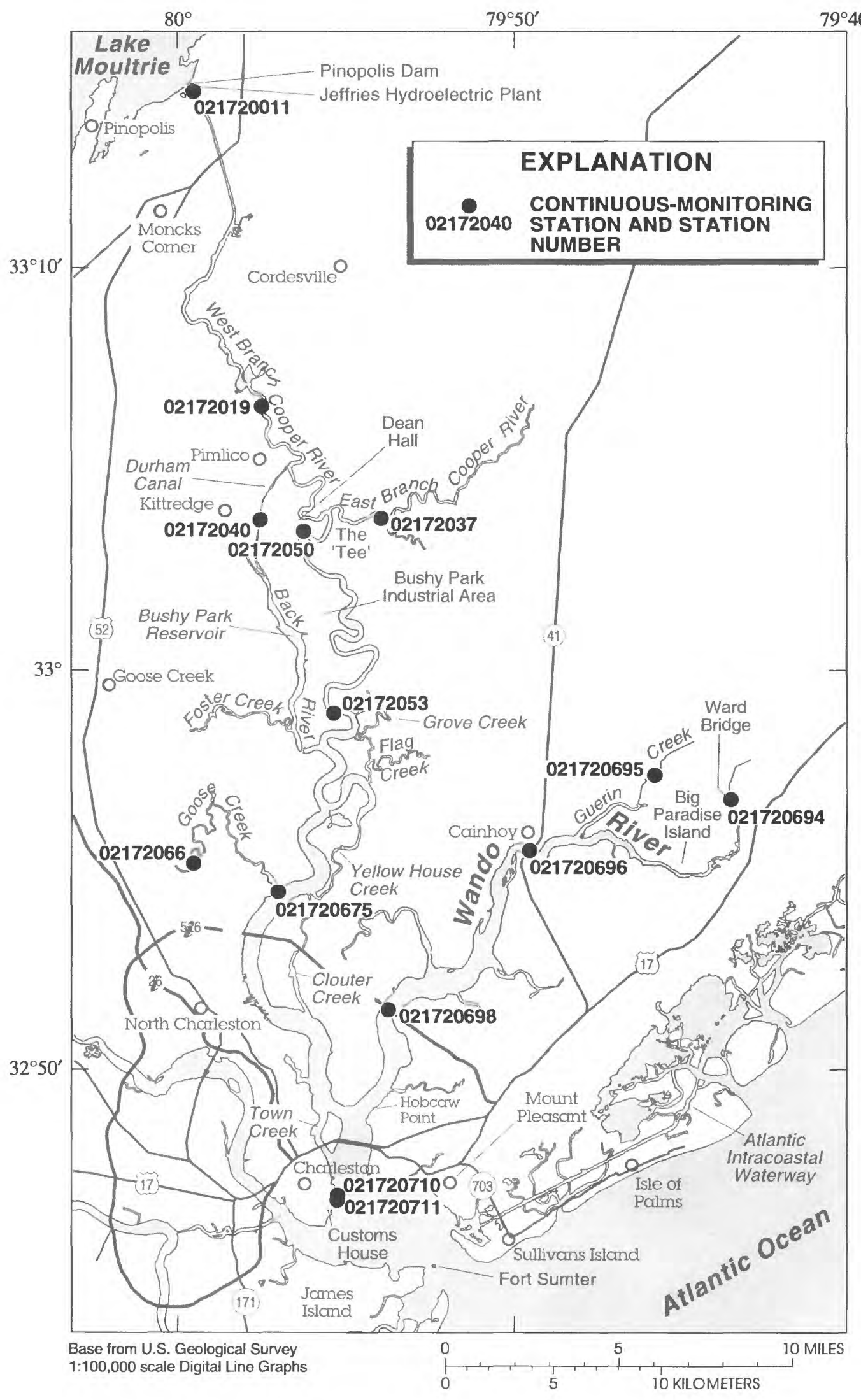

Figure 4. Location of continuous-monitoring stations on the Cooper and Wando Rivers and their tributaries, S.C. 
Table 2. Continuous water-level and water-quality stations on the Cooper and Wando Rivers, S.C., and the parameters monitored

[WL, water level; T, water temperature; DO, dissolved oxygen; SC, specific conductance]

\begin{tabular}{|c|c|c|c|}
\hline $\begin{array}{c}\text { Station num- } \\
\text { ber } \\
\text { (fig. 4) }\end{array}$ & $\begin{array}{c}\text { River miles } \\
\text { from } \\
\text { station } \\
\mathbf{0 2 1 7 2 0 7 1 1}\end{array}$ & Station name & Parameters \\
\hline 021720011 & 47.9 & Lake Moultrie tailrace near Moncks Corner, S.C. & WL, T, DO, SC \\
\hline 02172019 & 36.7 & West Branch Cooper River at Mepkin Abbey near Cordesville, S.C. & WL, SC \\
\hline 02172037 & 32.0 & East Branch Cooper River near Goose Creek, S.C. & $\mathrm{WL}, \mathrm{T}, \mathrm{DO}, \mathrm{SC}$ \\
\hline 02172040 & 35.1 & Back River at DuPont Intake near Kittredge, S.C. & $\mathrm{WL}, \mathrm{T}, \mathrm{DO}, \mathrm{SC}$ \\
\hline 02172050 & 28.9 & Cooper River near Goose Creek, S.C. & $\mathrm{WL}, \mathrm{T}^{1}, \mathrm{DO}^{1}, \mathrm{SC}^{1}$ \\
\hline 02172053 & 19.4 & Cooper River at Mobay near North Charleston, S.C. & $\mathrm{WL}, \mathrm{T}, \mathrm{DO}, \mathrm{SC}$ \\
\hline 02172066 & 17.0 & Goose Creek near Goose Creek, S.C. & WL \\
\hline 021720675 & 10.1 & Cooper River at Army Depot near North Charleston, S.C. & $\mathrm{WL}, \mathrm{T}^{1}, \mathrm{DO}^{1}, \mathrm{SC}^{1}$ \\
\hline 021720694 & 20.9 & Wando River above Cainhoy, S.C. & WL, T, DO, SC \\
\hline 021720695 & 18.3 & Guerin Creek above Cainhoy, S.C. & WL, T, DO, SC \\
\hline 021720696 & 12.7 & Wando River at Cainhoy, S.C. & $\mathrm{WL}, \mathrm{T}^{1}, \mathrm{DO}^{1}, \mathrm{SC}^{1}$ \\
\hline 021720698 & 5.9 & Wando River above Mount Pleasant, S.C. & $\mathrm{WL}, \mathrm{T}^{1}, \mathrm{DO}^{1}, \mathrm{SC}^{1}$ \\
\hline${ }^{2} 021720710$ & 0 & Cooper River at Customs House at Charleston, S.C. (Auxiliary) & $\mathrm{T}^{1}, \mathrm{DO}^{1}, \mathrm{SC}^{\mathrm{l}}$ \\
\hline 021720711 & 0 & Cooper River at Customs House at Charleston, S.C. & WL \\
\hline
\end{tabular}

${ }^{1}$ Near top and near bottom probes

${ }^{2}$ Station at same location as 021720711

\section{Nutrient Sampling}

Nutrient data used to calibrate and validate the BLTM were collected during two synoptic sampling periods in cooperation with the SCDHEC (fig. 5 and table 3). Samples were collected at 10 stations on the Cooper River and four stations on the Wando River. During the first synoptic sampling period, May 4-5, 1993, samples were collected during five slack tides over 2 days. During the second sampling period, August 23-25, 1993, samples were collected during five slack tides over 3 days. Field measurements of salinity, water temperature, and dissolved oxygen were made at the time of sample collection. Samples were analyzed in the SCDHEC laboratory in Columbia, S.C., for total ammonia nitrogen, total Kjeldahl nitrogen, total phosphorus, dissolved orthophosphorus, and chlorophyll-a. Total suspended solids were determined by the USGS Sediment Laboratory in Tuscaloosa, Ala. Ultimate carbonaceous biochemical oxygen demand $\left(\mathrm{CBOD}_{U}\right)$ and 30-day carbonaceous biochemical oxygen demand $\left(\mathrm{CBOD}_{30}\right)$ using a nitrogen inhibitor were determined by USGS personnel. 


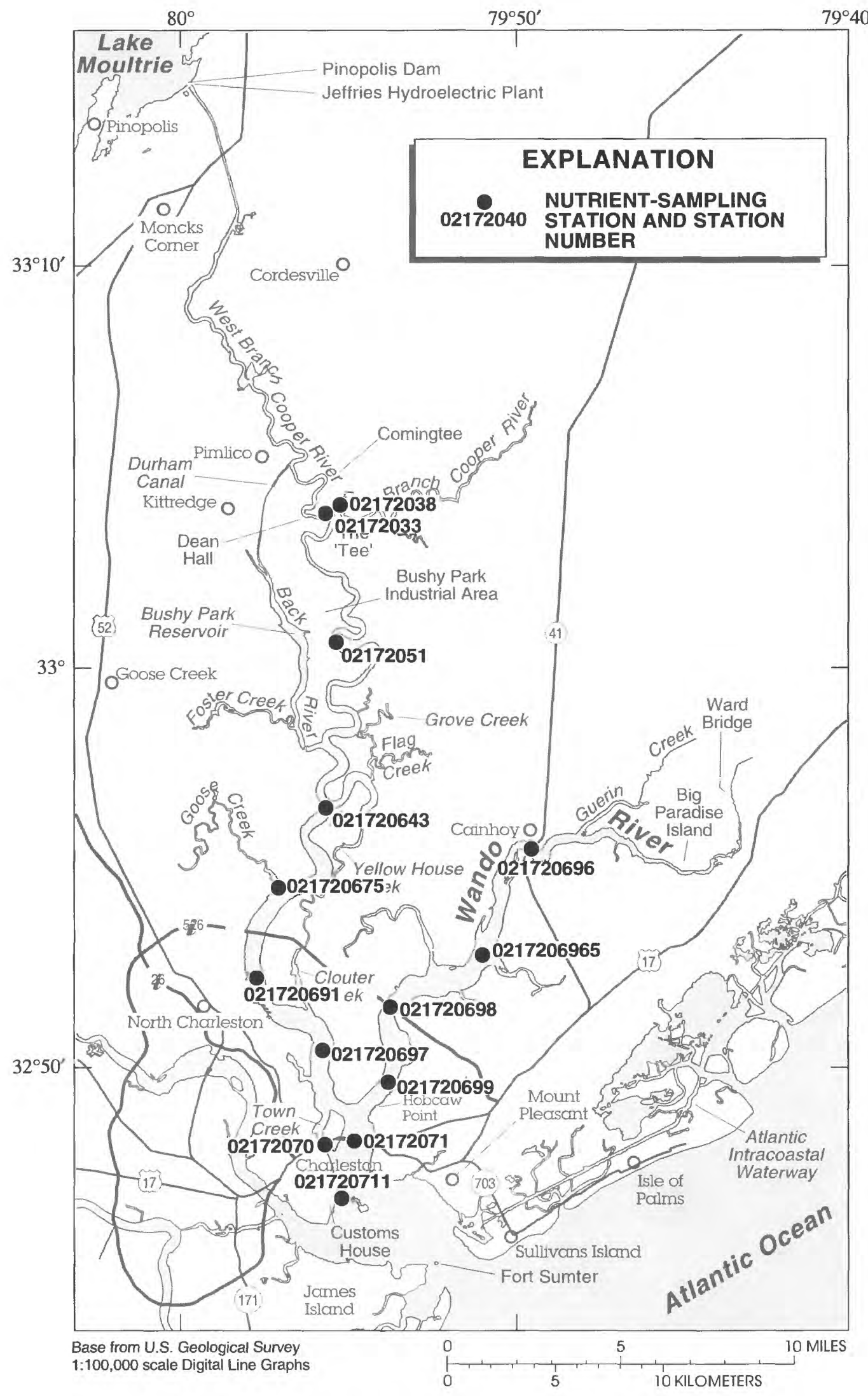

Figure 5. Location of nutrient-sampling stations on the Cooper and Wando Rivers and their tributaries, S.C. 
Table 3. Nutrient sampling stations on the Cooper and Wando Rivers, S.C.

\begin{tabular}{cccl}
\hline $\begin{array}{c}\text { Station number } \\
\text { (fig. 5) }\end{array}$ & $\begin{array}{c}\text { Storet num- } \\
\text { ber }\end{array}$ & $\begin{array}{c}\text { River miles from } \\
\text { station 021720711 }\end{array}$ & \multicolumn{1}{c}{ Station name } \\
\hline 02172033 & MD-770 & 30.2 & Cooper River below Comingtee, S.C. \\
02172038 & MD-769 & 30.1 & East Branch Cooper River near Comingtee, S.C. \\
02172051 & MD-771 & 25.0 & Cooper River at Cote Bas near North Charleston, S.C. \\
021720643 & MD-772 & 14.3 & Cooper River at Flag Creek near Goose Creek, S.C. \\
021720675 & MD-044 & 10.1 & Cooper River at Army Depot near North Charleston, S.C. \\
021720691 & MD-773 & 7.2 & Cooper River at Noisette Creek at North Charleston, S.C. \\
021720696 & MD-115 & 12.7 & Wando River at Cainhoy, S.C. \\
0217206965 & MD-774 & 9.4 & Wando River at Parker Island above Mount Pleasant, S.C. \\
021720697 & MD-045 & 3.7 & Cooper River above Shipyard Creek at North Charleston, S.C. \\
021720698 & MD-775 & 5.9 & Wando River near Mount Pleasant, S.C. \\
021720699 & MD-776 & 4.4 & Wando River at Hobcaw Point above Mount Pleasant, S.C. \\
02172070 & MD-047 & 1.5 & Town Creek at U.S. 17 at Charleston, S.C. \\
02172071 & MD-048 & 1.3 & Cooper River at Grace Memorial Bridge at Charleston, S.C. \\
021720711 & MD-777 & 0 & Cooper River at Customs House at Charleston, S.C. \\
\hline
\end{tabular}

\section{SIMULATION OF WATER LEVEL, STREAMFLOW, AND MASS TRANSPORT}

Simulation of the fate and transport of nutrients and dissolved oxygen in the Cooper and Wando Rivers first requires accurate simulations of water level, streamflow, and mass transport of the system. A onedimensional, dynamic-flow model (BRANCH) was used to simulate the hydraulic properties within the sys- tem. The one-dimensional, dynamic-transport model (BLTM) was used to simulate the conservative mass transport. The BLTM was then used to simulate the fate and transport of nutrients, $\mathrm{BOD}$, and dissolved oxygen. 


\section{Nater Level and Streamflow}

The BRANCH model is a one-dimensional, lynamic flow computer model for simulation of streamflow in interconnected channels (Schaffranek and others, 1981). The model solves the one-dimensional equations of continuity and motion:

$$
B \frac{\partial Z}{\partial t}+\frac{\partial Q}{\partial x}-q=0
$$

$$
\begin{gathered}
\frac{\partial Q}{\partial t}+\frac{\partial\left(\beta Q^{2} / A\right)}{\partial x}+g A \frac{\partial Z}{\partial x}+\frac{g k}{A R^{4 / 3}} Q|Q|-q u^{\prime} \\
-\xi B_{c} U_{a}^{2} \cos \alpha=0,
\end{gathered}
$$

where

$B$ is the total channel top width, in feet;

$Z$ is the stage, in feet;

$t$ is the time, in seconds;

$Q$ is the discharge, in cubic feet per second;

$x$ is the longitudinal distance along the channel, in feet;

$q$ is the lateral side-channel flow, in cubic feet per second, per foot;

$\beta$ is the dimensionless momentum coefficient; $A$ is the cross-sectional area, in square feet; $g$ is the gravitational acceleration constant, in feet per second per second;

$k$ is a function defining flow-resistance;

$R$ is the hydraulic radius, in feet;

$u^{\prime}$ is the $\mathrm{x}$-component of the lateral side-channel flow velocity, in feet per second;

$\xi$ is the dimensionless wind resistance coefficient;

$B_{c}$ is the top width of the conveyance part of the cross section, in feet; and

$U_{a}$ is the wind velocity in feet per second, occurring at an angle $\alpha$ from the positive $\mathrm{x}$-axis.

The flow-resistance function is expressed as $k=(\eta / 1.486)^{2}$, where eta is a flow-resistance coefficient.
In the derivation of equations 1 and 2 , it is assumed that the fluid is homogeneous in density. The channel is assumed (1) to be reasonably straight, (2) to be of simple geometry, such as having a rectangular or trapezoidal shape, and (3) to have a mild and uniform gradient. Approximate solutions for the nonlinear partial-differential dynamic flow equations are obtained by finite-difference techniques (Schaffranek and others, 1981). A weighted four-point finite-difference approximation is used in the BRANCH model.

In the model, rivers are represented as a series of cross sections and channel lengths, which define segments, junctions, and branches. Channel-geometry data that characterize the conveyance, area, width, and storage capacity at each cross section are input into the model. A segment is defined by an upstream and downstream cross section and the distance between them. A group of segments that is separated by junctions is called a branch. The beginning or ending junctions of a branch with no continuing branches is known as an external boundary. Water-level or streamflow data are input at the external boundaries as boundary conditions for the model. All other water levels and streamflows are computed at cross sections. An idealized BRANCH network model schematization is shown in figure 6 .

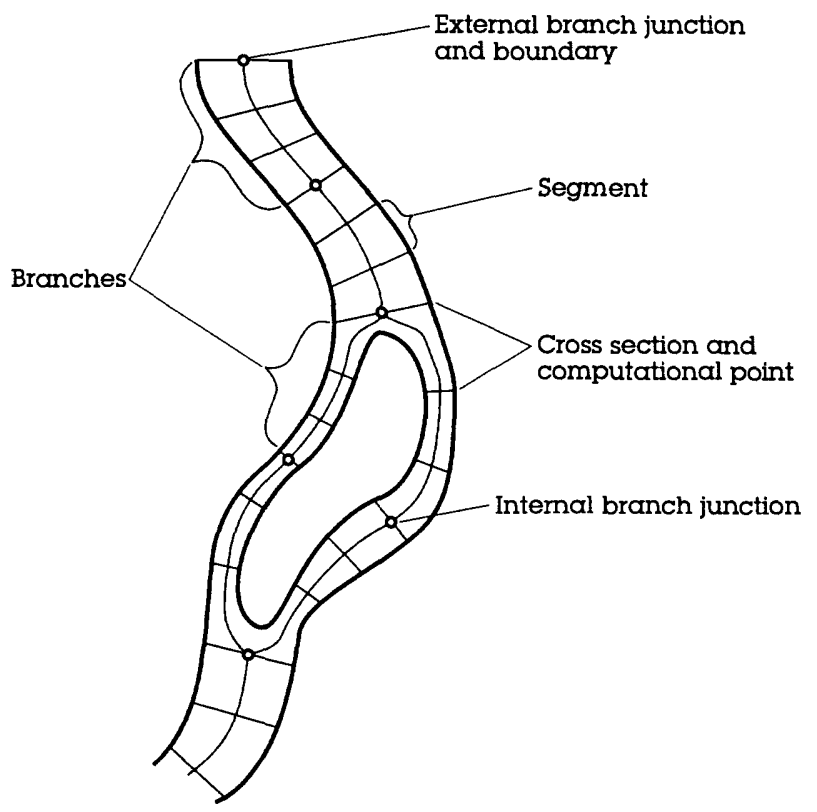

Figure 6. Idealized BRANCH model schematization. 
Although there are limitations to applying a onedimensional model to a tidal system, the BRANCH model can be applied successfully to the Cooper and Wando Rivers and the model has been successfully applied to several estuarine systems. Parts of the Cooper River are partially stratified. For extended periods, however, there is very little stratification. The complex channel geometry of old rice fields and tidal marshes can be simplified in BRANCH as large storage areas that fill and drain with each tidal cycle. BRANCH, unlike many other riverine models, also can simulate the converging and branching of interconnected channels. Bower and others (1993) applied the BRANCH model to the Cooper River and Bushy Park Reservoir to analyze retention times in the reservoir. Drewes and Conrads (1995) applied the BRANCH and BLTM models to the Waccamaw and Pee Dee Rivers and Atlantic Intracoastal Waterway to determine the assimilative capacity of the system. Weiss and others (1994) applied the BRANCH and BLTM models to the tidal Hudson River in New York to simulate streamflow and chloride transport.
The BRANCH model for the Cooper and Wando Rivers was schematized using 37 branches, 23 internal junctions, 156 cross sections, and 10 external boundaries (fig. 7). The BRANCH model of the Cooper River by Bower and others (1993) used water-level data for the upstream boundary at Pinopolis Dam (station 021720011). Streamflow data for the upstream boundary were used to facilitate the use of the model for various water-resource management scenarios involving different flow releases from the Pinopolis Dam. Flow data for Pinopolis Dam were provided by the South Carolina Public Service Authority. Waterlevel data were used as a boundary condition at Goose Creek near Goose Creek (station 02172066) and Cooper River at the Customs House (station 021720711). Flow boundaries of zero flow were used at upstream boundaries of five tidal creeks and sloughs where freshwater inflow into the system was negligible. Boundary locations, data types, data sources and data frequencies for the BRANCH model of the Cooper and Wando Rivers are summarized in table 4.

Table 4. Boundary locations, data types, data sources, and data frequency for BRANCH model of the Cooper and Wando Rivers, S.C.

[min, minutes; USGS, U.S. Geological Survey; --, no data]

\begin{tabular}{|c|c|c|c|c|}
\hline Boundary location & $\begin{array}{c}\text { External } \\
\text { boundary } \\
\text { number } \\
\text { (fig. 7) }\end{array}$ & Data type & Data source & $\begin{array}{c}\text { Data } \\
\text { frequency }\end{array}$ \\
\hline Pinopolis Dam Tailrace & 24 & Flow & S.C. Public Service Authority & $60 \mathrm{~min}$ \\
\hline Durham Canal & 25 & Flow & Simulated using BRANCH & $15 \mathrm{~min}$ \\
\hline East Branch Cooper River & 26 & Water level & USGS Station 02172037 & $15 \mathrm{~min}$ \\
\hline Grove Creek & 27 & Flow $=0$ & -- & -- \\
\hline Cooper River at Back River Dam & 28 & Flow $=0$ & -- & -- \\
\hline Flag Creek & 29 & Flow $=0$ & -- & -- \\
\hline Goose Creek & 30 & Water level & USGS Station 02172066 & $15 \mathrm{~min}$ \\
\hline Wando River & 31 & Flow $=0$ & -- & -- \\
\hline Guerin Creek & 32 & Flow $=0$ & -- & -- \\
\hline Cooper River at Customs House & 33 & Water level & USGS Station 021720711 & $15 \mathrm{~min}$ \\
\hline
\end{tabular}




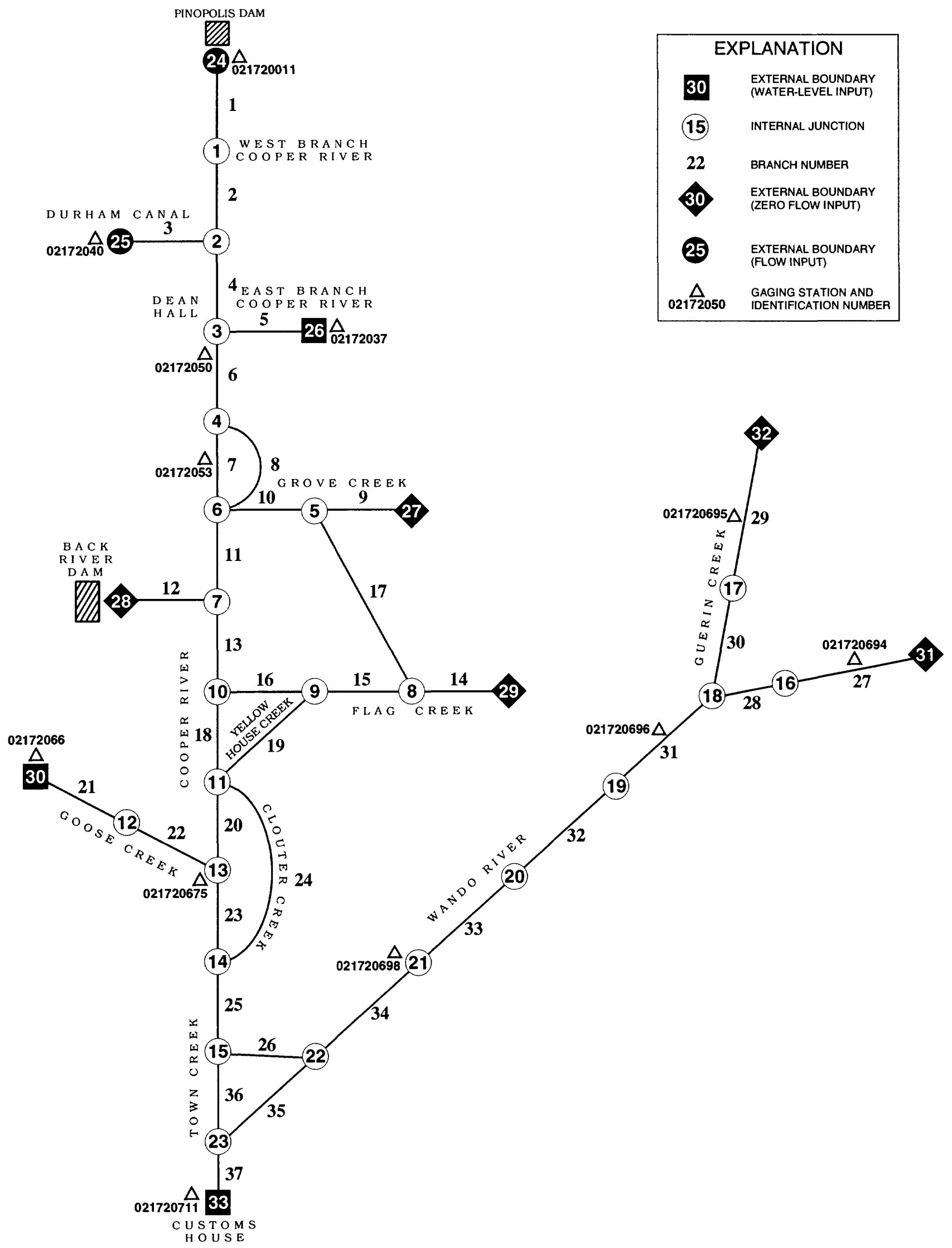

Figure 7. BRANCH model schematization for the Cooper and Wando Rivers, S.C. 


\section{Mass Transport}

The BLTM was used to simulate mass transport in the Cooper and Wando Rivers and their tributaries. The BLTM solves the convective-dispersion equation by using a Lagrangian-reference frame in which the computational nodes move with the flow (Jobson and Schoelhamer, 1987). In the Lagrangian-reference frame, the continuity of mass equation is:

$$
\frac{\partial C}{\partial t}=\frac{\partial}{\partial \xi}\left[D \frac{\partial C}{\partial \xi}\right]+S+\Phi+K(C-C R),
$$

where

$C$ is the concentration, in milligrams per liter;

$t$ is time, in seconds;

$\xi$ is the Lagrangian-distance coordinate, in feet;

$D$ is the longitudinal dispersion coefficient, in square feet per second;

$S$ is the rate of production of the concentration, which is independent of the concentration (zero-order production rate), in milligrams per liter per second;

$\Phi$ is the rate of change in concentration due to tributary inflow, in milligrams per liter per second;

$K$ is the rate of production of the constituent, in per second; and,

$C R$ is the equilibrium concentration (that is, the concentration at which the internal production ceases), in milligrams per liter.

The Lagrangian-distance coordinate, $\xi$, is given by

$$
\xi=x-x_{o}-\int_{t_{o}}^{t} u d t
$$

where

$x$ is the Eulerian (stationary) distance coordinate along the river, in feet;

$x_{o}$ is the location of the parcel of water at time $t_{0}$; and,

$u$ is the cross-sectional mean stream velocity, in feet per second.
The BLTM uses a dimensionless dispersion factor in the Lagrangian transport solutions. The dispersion factor is inversely proportional to the square of the stream velocity. The factor is defined as:

$$
\mathrm{D}_{f}=\frac{\mathrm{D}}{\Delta t \mu^{2}}
$$

where

$\mathrm{D}_{f}$ is dispersion factor, dimensionless;

$\mathrm{D}$ is dispersion rate, in square feet per second;

$\Delta t$ is simulation time step, in seconds; and

$\mu$ is the representative stream velocity, in feet per second.

The advantage of the Lagrangian-reference frame, especially in a mesotidal environment such as the Cooper and Wando Rivers, is that there is minimal numerical dispersion. The BLTM assumes that parcels of water are completely mixed and that volumes are affected only by tributary flows. The variation of concentrations in space and time in a river reach is approximated by solving equation 3 for a series of parcels spaced along the river at intervals approximately equal to $\mu \Delta t$. The concentration at any point is the concentration of the parcel at that point. The assumption of completely mixed parcels may cause interpolation errors when determining the concentration of a given point. The advantage of a Lagrangian model, as compared to an Eulerian model, is that this interpolation error applies only to the output computations. The grid concentration is not used in further computations and, therefore, the error is not compounded. In an Eulerian model, similar interpolation errors are made at every time step, and grid concentrations are used as the basis for all further computations, resulting in compounding errors (Jobson, 1981). In BLTM, some numerical dispersion is introduced into the solution scheme at internal junctions.

The main advantages of the Lagrangian approach, as outlined above, are (1) the scheme is more accurate in modeling the convection and dispersion terms than the Eulerian approach (Jobson, 1980; Thomson and others, 1984), and (2) the Lagrangian model is stable for any time step (Jobson, 1981). 
The BLTM for the Cooper and Wando Rivers is schematized using 30 branches, 10 external boundaries, and 16 internal junctions (fig. 8). The schematization of the BLTM is different from the BRANCH schematization in two significant ways. First, internal junctions in the BRANCH model that do not have branching segments were removed to minimize numerical dispersion. Second, a zero-flow boundary condition was not used for the upper boundaries on the Wando River and Guerin Creek where there are significant salinity concentrations. Boundary-constituent concentrations are input into BLTM as a flux, so boundary data must be associated with a flow to be brought into the model domain. The boundary locations were set at the locations of gaging stations 021720694 and 021720695 , respectively (figs. 4,8 ). At the other tidal creeks with zero-flow boundaries and where there were no continuous salinity data, a zeroflow boundary was used.

The flow field generated by BRANCH of the hydraulic properties for every cross-section had to be modified to exclude the upper reaches of the Wando River and Guerin Creek, where the hydraulic model had been extended to accommodate the zero-flow boundary. To ensure that mass was being conserved, the BLTM was run using a 15-day tidal-flow field, and the initial conditions and boundary salinity data were set at $20 \mathrm{ppt}$. The model predicted salinity concentrations of $20 \mathrm{ppt}$ for the 15-day period in every branch, therefore, mass was conserved.

\section{Calibration and Validation of Dynamic- Flow and Mass-Transport Models}

The BRANCH flow and the BLTM mass-transport models were calibrated and validated using field measurements of water level, streamflow, and calculated salinity concentrations. The results of the calibration, validation, and sensitivity analyses of the two models are documented by Conrads and Smith (1996). In that report, results of the flow-model calibration and validation are presented in hydrographs of simulated and measured water level and streamflow, and results of the transport-model calibration and validation are presented in hydrographs of simulated and calculated salinity. The mass-transport model was sensitive to changes in the gage datum of the downstream waterlevel boundary used in the BRANCH model. Satisfactory calibration of the mass-transport model was achieved by applying a positive 0.45 -ft datum adjustment to the downstream water-level boundary data.

Summary statistics were generated to quantify the error of the calibration and validation simulations and were presented in tabular form (Conrads and Smith, 1996). Summary statistics for water-level simulations included timing error, mean of the residuals, and the standard deviation of the residuals. Of the 11 water-level simulations used in the calibration and validation of the model, seven had timing errors of 15 minutes or less, two had timing errors of 30 minutes, and two had timing errors of 45 minutes. For the waterlevel simulations, the mean of the residuals ranged from -0.20 to $0.63 \mathrm{ft}$, and the standard deviations of the residuals ranged from 0.12 to $0.45 \mathrm{ft}$.

Summary statistics for the streamflow simulations included timing error, an index of the mean of the residuals (given as a percentage), and an index of the standard deviations of the residuals (also given as a percentage). The indices are not a true percentage, because they will not be representative throughout the range of streamflows of the simulations (especially when those values are low or pass through zero). For the 18 simulations, the index of the mean of the residuals ranged from -18.4 to 7.4 percent. For the four simulations made at the upstream boundaries of the Wando River and Guerin Creek, where the streamflows are two orders of magnitude less than the mainstem, the indices of the standard deviation of the mean of the residuals were high ( 43.2 to 66.9 percent). For the remaining 14 simulations, the indices of the standard deviation of the residuals ranged from 12.0 to 25.7 percent.

Summary statistics for the salinity simulations included timing error, index of the mean of the residuals, and an index of the standard deviation of the residuals. Of the seven calibration and validation simulations, two had timing errors of 60 minutes, three had timing errors of 120 minutes, and two did not have enough data to compute the timing error. Five of the simulations had indices of the mean of the residuals and the standard deviation of the residuals that ranged from -4.4 to 21.3 percent and from 1.9 to 9.4 percent, respectively. In the two simulations where the mean salinity concentrations were low (3.0 ppt or less), the summary statistics were high. The indices of the mean of the residuals and standard deviation of the residuals ranged from -38.9 to 76.8 percent and 52.6 to 58.7 percent, respectively. 


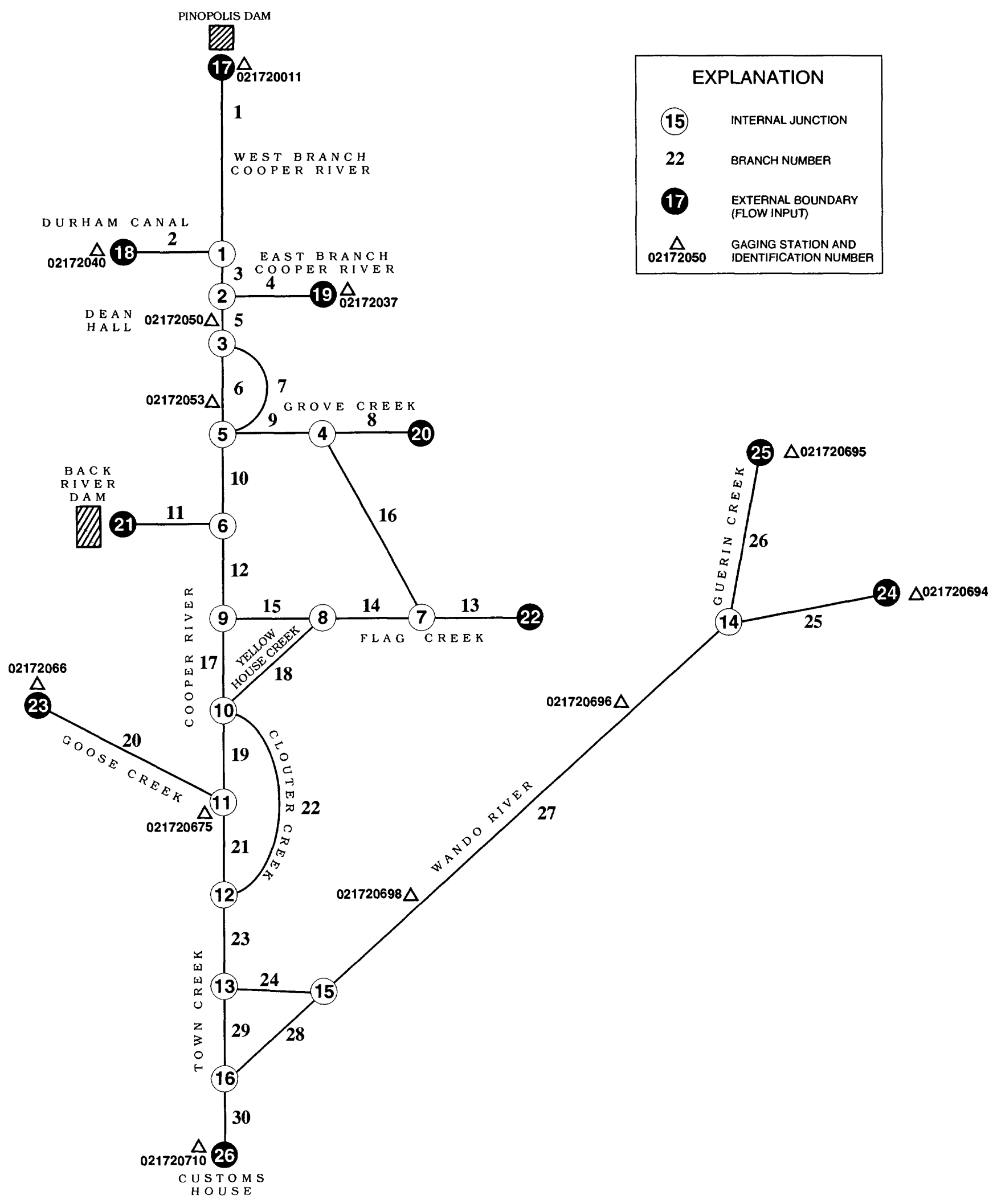

Figure 8. Branched Lagrangian Transport Model schematization for the Cooper and Wando Rivers, S.C. 


\section{SIMULATION OF TEMPERATURE, NUTRIENTS, BIOCHEMICAL OXYGEN DEMAND, AND DISSOLVED OXYGEN}

To simulate the fate and transport of nutrients, BOD, and dissolved oxygen, BLTM uses the waterquality reaction kinetics found in the QUAL2E model (Brown and Barnwell, 1987; Jobson and Schoelhamer, 1987; Jobson, 1997). The model can simulate up to 10 major water-quality constituents that affect dissolvedoxygen concentration dynamics. The model has the ability to simulate multiple wastewater discharges, withdrawals, tributary flows, and incremental inflows and outflows. A conceptualization of the constituents and their interactions in the QUAL2E and BLTM models is shown in figure 9.

The rates of most chemical and biological reactions are temperature dependent so it is necessary to accurately simulate the water temperature of the system. The QUAL2E routines in BLTM uses an equilibrium temperature algorithm to simulate the water temperature (Jobson, 1977, 1980, 1997). The equilibrium temperature is defined as the water temperature at which the net surface heat exchange becomes zero.

For example, a pool of water would come to this temperature and remain at this temperature as long as the meteorological conditions remained constant.

Applying the principle of conservation of energy to a one-dimensional open channel, the Lagrangian form of the equation becomes:

$$
\frac{d T}{d t}+U \frac{d T}{d x}-\left(D_{x} \frac{d^{2} T}{d x 2}\right)=\frac{H_{t} W}{C_{p} \rho A},
$$

where $\mathrm{T}$ is the cross-sectional average water temperature, $t$ is time, $U$ is stream velocity, $x$ is the longitudinal coordinate, $\mathrm{D}_{\mathrm{x}}$ is the longitudinal dispersion coefficient, $H_{t}$ is the flux of thermal energy from the air to the water, $\mathrm{W}$ is the top width of the channel, $\mathrm{C}_{\mathrm{p}}$ is the specific heat of water at constant pressure, $\rho$ is the density of water, and $A$ is cross-sectional area. The term on the right side of equation 6 represents the rate of change of water temperature due to the exchange of energy between the atmosphere and water.

The simulation of temperature can be simplified by determining the equilibrium temperature. Often, it is easier to estimate the equilibrium temperature than to measure all the necessary meteorological inputs (solar radiation, atmospheric radiation, wind speed, air temperature, and relative humidity). Time-series estimates of equilibrium temperature for the calibration and validation time periods were computed using the program EQULTMP (Jobson, 1997). The program uses inputs of daily extremes of air temperature (and their respective times) and average daily wind speed to compute the equilibrium temperatures for a specified time step.

The QUAL2E subroutine in BLTM simulates the growth of algae, which is dependent on the amount of available solar radiation. Time-series estimates of solar radiation were computed using the program SOLAR (Jobson, 1997). Inputs for the program include; longitude, longitude of the local time meridian, latitude, altitude of sunrise and sunset, atmospheric pressure, coefficients in empirical equation to determine precipitable water content of the atmosphere, cloud cover, and dew point.

After the preliminary calibration of the waterquality model, four modifications to the model were made for application to the Cooper and Wando Rivers. The model was simulating too much nitrate concentrations in excess of measured concentrations, and adjustments to the oxidation kinetics did not reduce the concentrations. Applications of BLTM and other models based on the QUAL2E kinetics have encountered similar elevated nitrate concentrations. In modeling dissolved-oxygen concentrations on the Chattahoochee River in Georgia with BLTM, Jobson (1985) applied a nitrate loss factor during the oxidation of nitrite to nitrate. The Tailrace Water-Quality Model (Dortch and others, 1992) and the CE-QUAL-RIV1 model (Environmental Laboratory, 1995) included a denitrificationin-sediments term to account for a loss of nitrate. The kinetics of QUAL2E was modified to include a loss factor (NO2L, fig. 9) during the oxidation of nitrite to nitrate.

In QUAL2E, the recommended range of values for the settling rate of BOD is from -0.36 to 0.36 day $^{-1}$. The negative rate values change the settling rate of BOD to a source rate for BOD. The settling terms in the model are based on a percentage of the instream concentration of the constituent. The source terms are based on a benthic flux of the constituents from the streambed and are independent of the instream concentration of the constituent. The units for the source term are not consistent when the sign is changed to create a settling term. By reversing the sign on a settling term, 


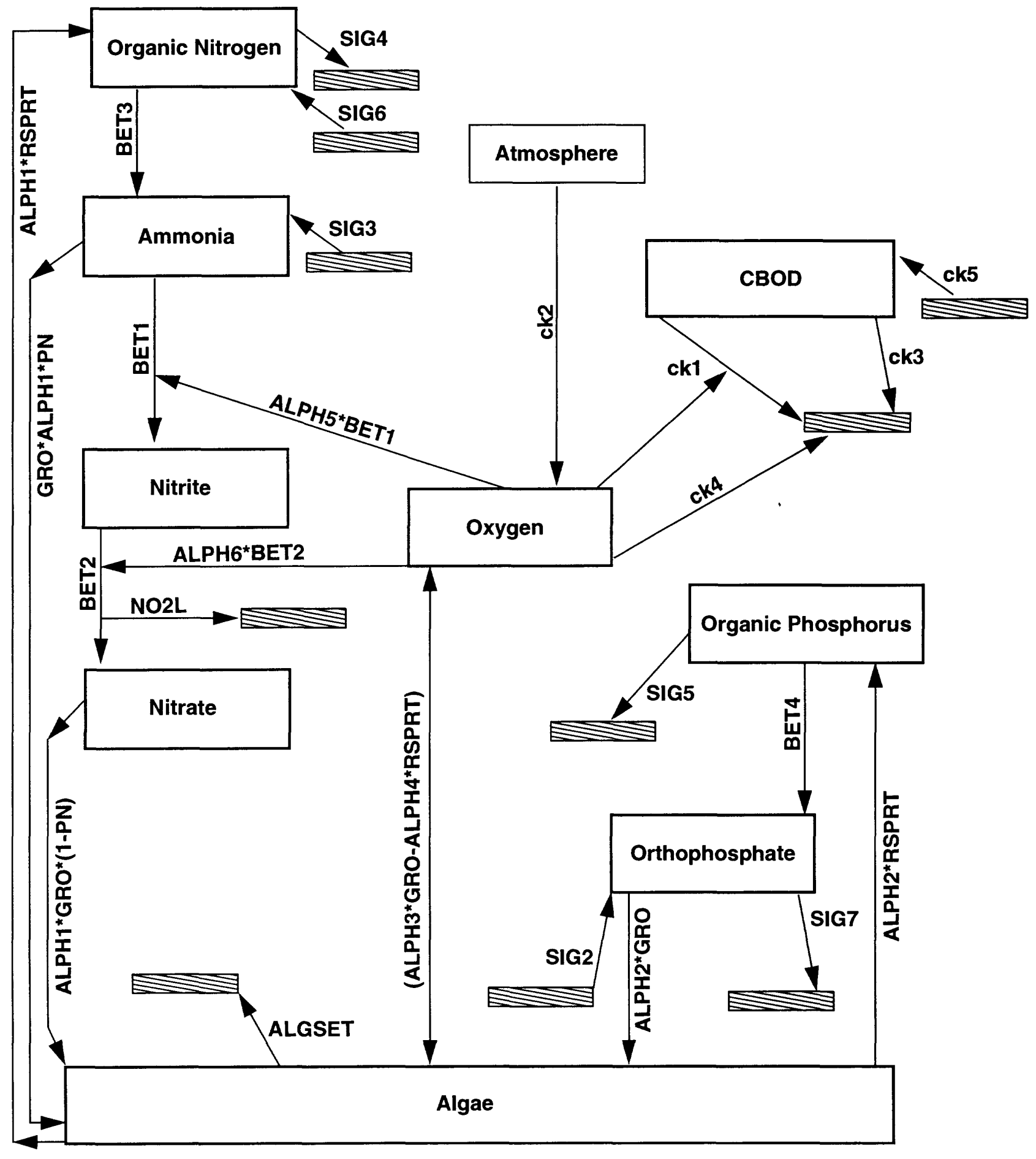

Figure 9. Major constituent interactions in the QUAL2E model and Branched Lagrangian Transport Model. 
the benthic flux is then proportional to the instream concentration of the constituent. To be consistent with the units in the model, a separate BOD source term (CK5, milligrams per liter of BOD per square foot per day) (fig. 9) was included in the QUAL2E kinetics in BLTM.

A source term for organic nitrogen and a settling term for dissolved phosphorus were needed for application of the model to the Cooper and Wando Rivers. The QUAL2E model code already included a settling term for organic nitrogen and a source term for dissolved phosphorus. Rather than reverse the signs for the settling term for organic nitrogen and the source term for dissolved phosphorus, the QUAL2E kinetics were modified to include two additional terms: a source term for organic nitrogen (SIG6, milligrams per liter of organic nitrogen per square foot per day) (fig. 9) and a settling term for dissolved phosphorus (SIG7, milligrams per liter of dissolved phosphorus per square foot per day).

\section{Calibration and Validation of Water Temperature}

The BLTM was calibrated and validated using continuous water-temperature data collected concurrently with the synoptic nutrient sampling during August 23-25, 1993, and May 4-5, 1993, respectively. Water-temperature data were collected at two continuous-monitoring stations on the Cooper River (stations 02172050 and 021720675 ) and at two continuousmonitoring stations on the Wando River (stations 021720696 and 021720698 ) (fig. 4, table 2).

The temperature algorithm in BLTM uses an empirical wind function that was derived from a thermal balance of the San Diego Aqueduct (Jobson, 1977), which takes the form:

$$
\Psi=3.01+1.13 \mathrm{~V},
$$

where

$\Psi$ is wind function that give evaporation in millimeters per day (when the vapor pressure deficit is expressed in kilopascals);

$\mathrm{V}$ is wind speed in meters per second.
The first constant, 3.01 , is the free convection coefficient (Al) and the second constant, 1.13, is the mass transfer coefficient for evaporation coefficient (B1). Water-temperature simulations were calibrated by adjusting these coefficients in the wind function of the BLTM.

Results of the temperature calibration and validation are presented as 30-day time-series plot for August and April-May 1993, respectively (figs. 10, 11). For the August calibration period, the simulated temperature generally was less than the measured water temperature by one or two degrees Celsius $\left({ }^{\circ} \mathrm{C}\right)$ (fig. 10). In all of calibration simulations, the simulated temperatures followed the trend of the measured temperature.

The simulated water temperature for the AprilMay validation period was higher than the measured water temperature (fig. 11). Unlike the August dataset where there was only a 2 - to 3 -degree variation over the 30-day simulation period, there was a $8^{\circ} \mathrm{C}$ temperature difference during the April-May simulation period. The model overestimates the water temperature at the downstream station on the Cooper River (fig. 11b) and the two stations on the Wando River (figs. 11c, 11d). Although some of the simulated water temperatures were as much as $8^{\circ} \mathrm{C}$ higher than the measured water temperatures, the simulated water temperatures were within $2{ }^{\circ} \mathrm{C}$ of the measured temperatures for the two Cooper River stations (figs. 11a, 11b) and within $3{ }^{\circ} \mathrm{C}$ for the two Wando River stations (figs. 11c, 11d) by the end of the 30-day period.

The water temperature simulations for the AprilMay validation period can be greatly improved by using different $\mathrm{Al}$ and $\mathrm{Bl}$ coefficients than the August calibration period, but emphasis was placed on the calibration period. The differences in the coefficients may be due to differences in relative humidity and evaporation between the April-May and August datasets.

Although the same coefficients are used for the AprilMay and August period in this study, the use of different $\mathrm{A} 1$ and $\mathrm{B} 1$ coefficients for different simulation periods could be justified due to the importance of water temperature on the reaction kinetics. 

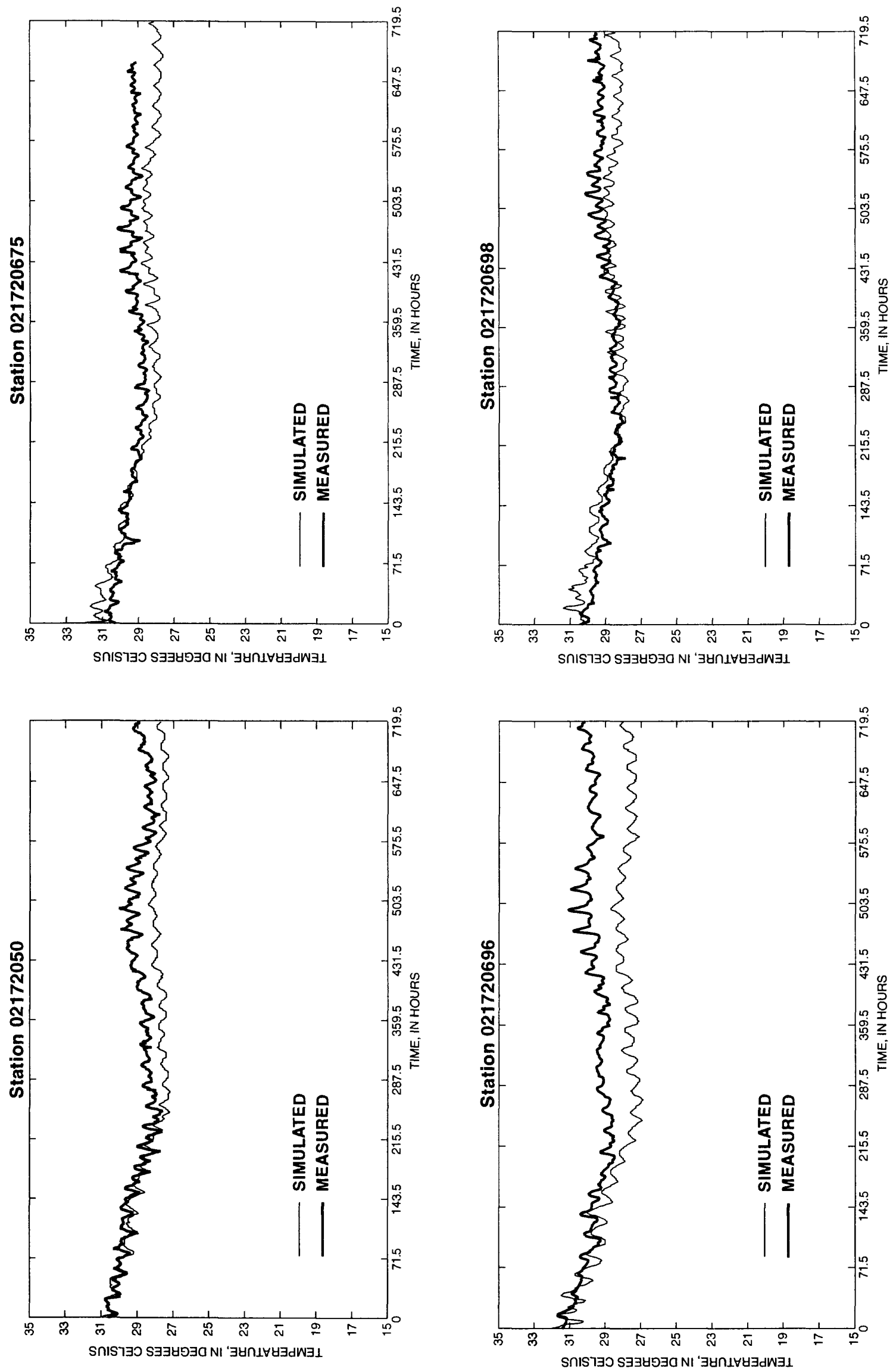

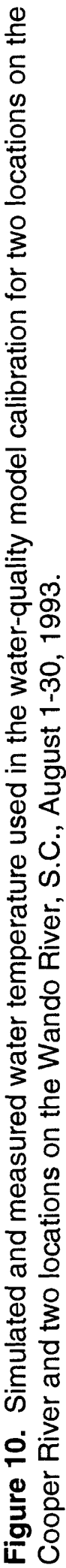



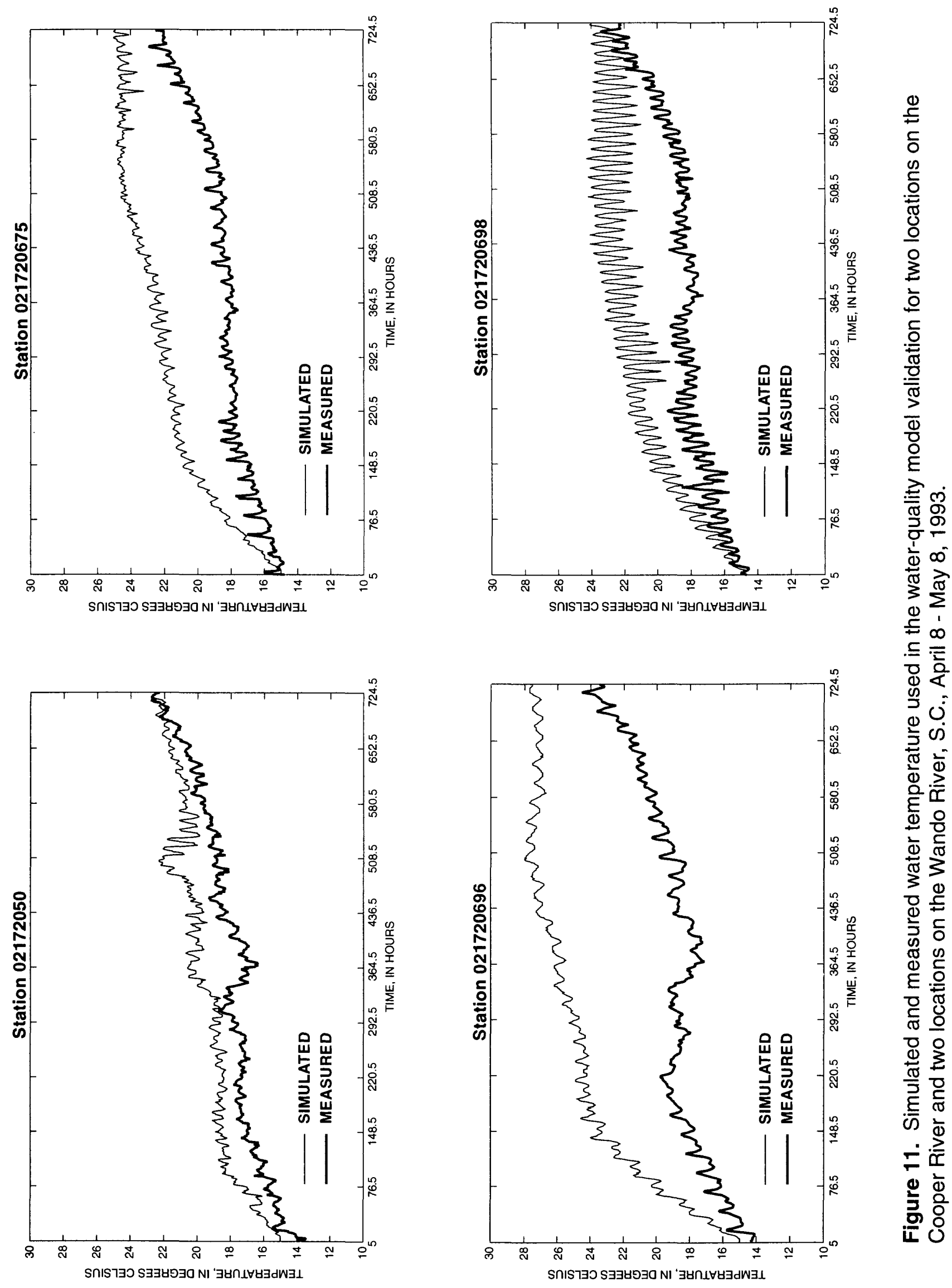


\section{Calibration and Validation of Nutrients, Biochemical Oxygen Demand, and Dissolved Oxygen}

Eight parameters were simulated using the BLTM for the Cooper and Wando Rivers: water temperature, dissolved oxygen, algae, organic nitrogen, ammonia, nitrate, dissolved phosphorus, and BOD. The water-quality parameter of most interest to the SCDHEC is dissolved oxygen. Dissolved-oxygen concentration is dependent on many factors, including water temperature, streamflow, atmospheric reaeration, photosynthesis, plant and animal respiration, BOD, nitrification, and benthic oxygen demand. The wastewater permittees discharge ammonia and BOD into the Cooper and Wando Rivers; both parameters have a significant effect on dissolved-oxygen concentration.

The BLTM was calibrated and validated using nutrient data collected August 23-25, 1993 and May 45,1993 , respectively. The critical period for dissolved oxygen is during the warm summer months. The August dataset was used for calibration because it closely approximated the "critical conditions" used for wasteload allocation. Because the model will ultimately be used to determine wasteload allocations for ammonia, BOD, and dissolved oxygen, emphasis was placed on satisfactory simulations of these constituents during calibration and validation.

Thirty-day datasets for the eight modeled constituents were generated for each boundary of the model for the calibration and validation periods. Continuous (hourly) temperature and dissolved-oxygen data were used at the external boundaries for the following stations: Lake Moultrie Tailrace near Moncks Corner (station 021720011), East Branch Cooper River near Goose Creek (station 02172037), Back River at DuPont Intake near Kittredge (station 02172040), Wando River above Cainhoy (station 021720694), Guerin Creek above Cainhoy (station 021720695), and Cooper River at the Customs House at Charleston (station 021720710). For the other six constituents, concentration data from each sampling location corresponding with a boundary were averaged and used as the steady-state boundary concentration. Boundary data were not collected in Goose Creek, therefore, STORET data were taken from SCDHEC monthly monitoring for boundary data. Data of daily high and daily low air temperature and wind speed from Charleston Airport were used to estimate the necessary meteorological input data for each dataset of wind speed, equilibrium temperature, and solar radiation (National Oceanic and Atmospheric Administration, 1993a-d). Point-source effluent concentrations during the two sampling periods were reported by the permitted dischargers. These data were averaged over the calibration and validation sampling periods and entered into the model as point-source loads.

The water-quality model was calibrated by adjusting constant (global) and variable (local) kinetic rate coefficients within ranges described by Bowie and others (1985) and Brown and Barnwell (1987) until the simulated constituent concentrations approximated the measured concentrations. Simulated concentrations were considered acceptable when the average simulated constituent concentrations for the period of observed data fell within the range of observed concentrations for a given location. Kinetic rate coefficients used in the model and recommended values are listed in table 5 .

For the calibration and validation simulations, model output for each of the seven constituents consisted of hourly values over a 30-day period (720 simulated data points). Measured data for the calibration and validation were limited to five data points for each constituent at approximately 12-hour intervals over 2 or 3 days. This approach was used to examine only those simulated data that corresponded to the time of measured data. Therefore, for each 30-day simulation, only the simulated data concurrent with the measured data were averaged and compared with the measured data. The criterion used to evaluate calibration and validation of the model was a target range that was bracketed by the maximum and minimum concentrations of the measured data. This criterion was considered achieved when the simulated mean fell within the range of the measured data. Simulated means also were compared to a calculated range 20 percent larger than the actual measured range to include those simulated means that did not meet the defined criterion, but were considered close to meeting it. A standard deviation was calculated for simulated data over this period in order to compare the simulated constituent concentration variability with actual measured data variability.

Measured ammonia concentrations were equal to or less than $0.05 \mathrm{mg} / \mathrm{L}$, the lower limit of detection for the analysis, at all 14 sampling stations. Because 

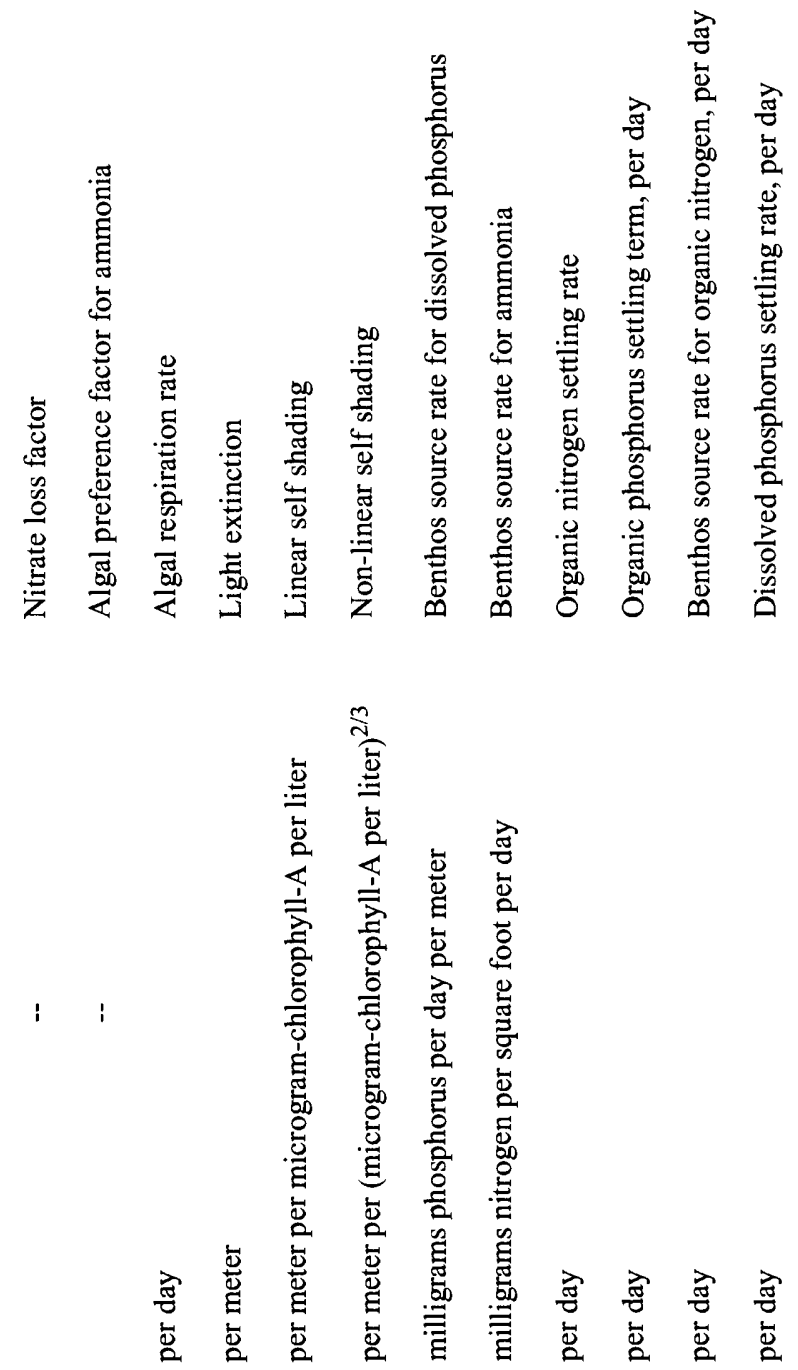
there was no variability to the measured data, the evaluation criterion could not be applied. Therefore, the range from 0.04 to $0.06 \mathrm{mg} / \mathrm{L}$ was defined as the evaluation criterion for the simulated mean ammonia concentrations.

Results of the water-quality model calibration and validation are presented as longitudinal profiles of constituent concentrations versus river mi (tables 2 and 3) from the Customs House (station 021720711) for the Cooper and Wando Rivers (figs. 12, 13, 15, and 16) and as time serves of dissolved-oxygen concentration for gaging station locations (figs. 14, 17). The mean simulated values and one standard deviation are shown with the minimum and maximum observed values except for the ammonia values where the measured data was at or below $0.05 \mathrm{mg} / \mathrm{L}$, the lower limit of detection (figs. 12c and 13c). The percent of stations meeting the calibration and validation criterion and expanded criterion for each constituent are shown in table 6.

For the calibration period, 93 percent of the mean simulated dissolved-oxygen concentration meet the criterion and the simulated mean values follow the trend of the measured values on the Cooper and Wando Rivers (table 6, figs. 12g and 13g). The longitudinal profile of simulated and measured dissolved-oxygen concentrations for the Cooper River show the mini- mum measured and simulated mean dissolved-oxygen concentration to occur near the mouth of Goose Creek (station 021720675, river mile 10.1). The simulated dissolved-oxygen concentrations on the Wando River show an increasing concentration in the upper reaches of the river that is not as evident in the measured data. The model also is overestimating the increasing algal biomass concentrations in the upper reaches of the Wando River (fig. 13a) and the increasing dissolvedoxygen concentrations in this reach may be due to overestimating oxygen production by photosynthesis

The mean simulated $\mathrm{CBOD}_{\mathrm{u}}$ concentration meet the criterion at 79 percent of the stations and the measured and mean simulated $\mathrm{CBOD}_{\mathrm{u}}$ concentrations follow the trend of the Cooper River of increasing concentrations from upstream to downstream (table 6, figs. $12 \mathrm{f}$ and $13 \mathrm{f}$ ). The mean simulated ammonia concentrations meet the criterion at 79 percent of the stations, but the model is responding to a large pointsource ammonia discharge in the lower Cooper River (table 1) that is not observed in the measured data (table 6 , figs. $12 \mathrm{c}$ and $13 \mathrm{c}$ ). The mean simulated nitrate concentration meet the criterion at 79 percent of the stations and closely follow the trend of the measured data on the Cooper River (table 6, figs. 12d and 13d).

In addition to comparing the simulated dissolved-oxygen concentrations to the measured field

Table 6. Percent of stations meeting calibration and validation criteria for seven constituents $\left[\mathrm{CBOD}_{\mathfrak{u}}\right.$, ultimate carbonaceous oxygen demand]

\begin{tabular}{|c|c|c|c|c|}
\hline \multirow[b]{2}{*}{ Constituent } & \multicolumn{2}{|c|}{$\begin{array}{l}\text { Calibration simulation } \\
\text { (August 23-25, 1993) }\end{array}$} & \multicolumn{2}{|c|}{$\begin{array}{l}\text { Validation simulation } \\
\text { (May 4-5, 1993) }\end{array}$} \\
\hline & $\begin{array}{l}\text { Stations meeting } \\
\text { criterion }{ }^{1} \\
\text { (percent) }\end{array}$ & $\begin{array}{l}\text { Stations meeting } \\
\text { expanded crite- } \\
\text { rion }{ }^{2} \text { (percent) }\end{array}$ & $\begin{array}{l}\text { Stations meeting } \\
\text { criterion }{ }^{1} \\
\text { (percent) }\end{array}$ & $\begin{array}{l}\text { Stations meeting } \\
\text { expanded criterion } \\
\text { (percent) }\end{array}$ \\
\hline Algae biomass & 36 & 57 & 21 & 21 \\
\hline Organic nitrogen & 71 & 86 & 36 & 50 \\
\hline Ammonia nitrogen & 79 & 93 & 71 & 79 \\
\hline Nitrate nitrogen & 79 & 86 & 57 & 64 \\
\hline Total phosphorus & 79 & 79 & 100 & 100 \\
\hline $\mathrm{CBOD}_{\mathrm{u}}$ & 79 & 79 & 79 & 86 \\
\hline Dissolved oxygen & 93 & 93 & 79 & 93 \\
\hline
\end{tabular}

\footnotetext{
${ }^{1}$ Mean simulated constituent concentration during sampling period within the range of the minimum and maximum measured concentration.

${ }^{2}$ Mean simulated constituent concentration during sampling period within a range twenty percent larger than the range of the minimum and maximum measured concentration.
} 

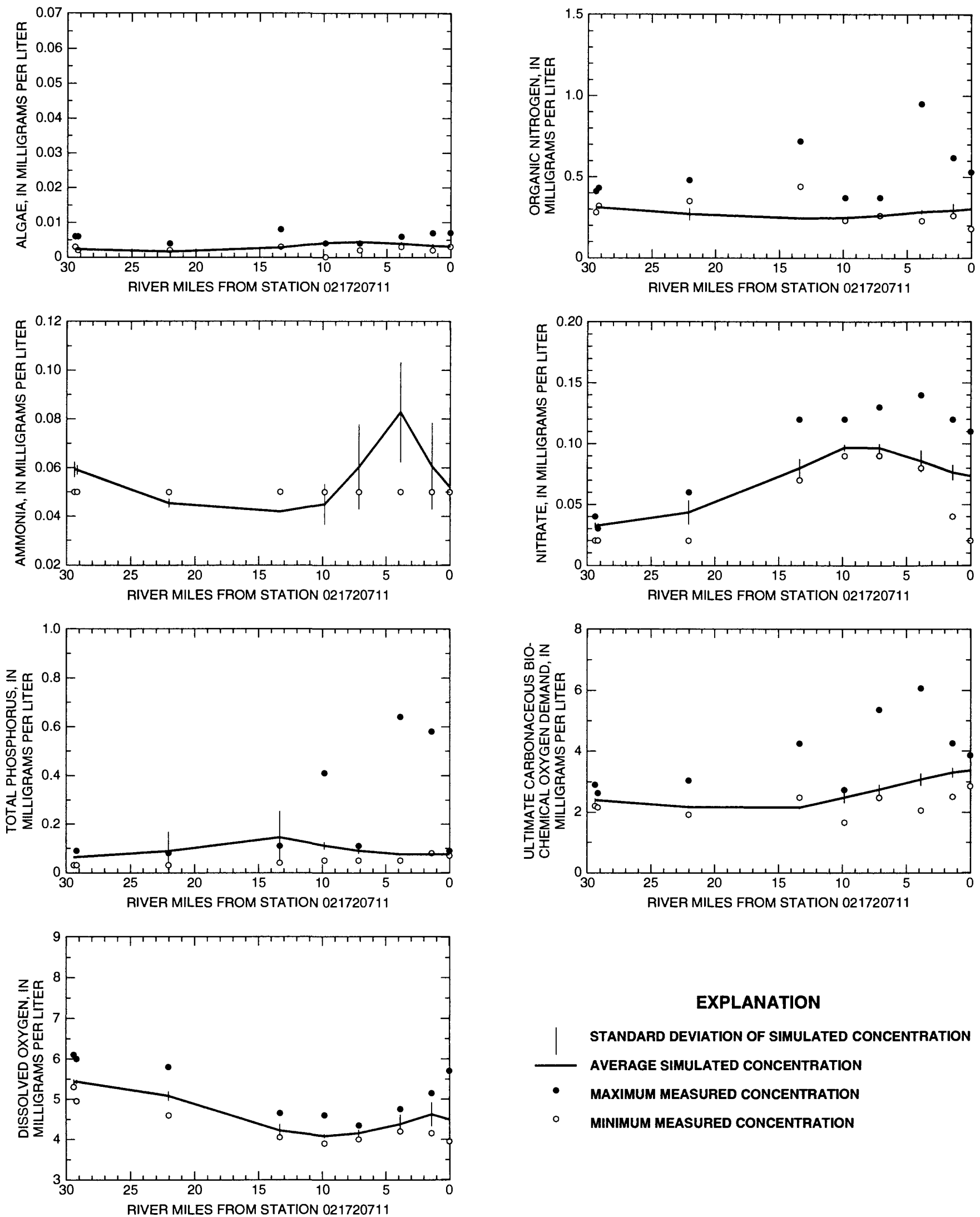

\section{EXPLANATION}

STANDARD DEVIATION OF SIMULATED CONCENTRATION AVERAGE SIMULATED CONCENTRATION

- MAXIMUM MEASURED CONCENTRATION

- MINIMUM MEASURED CONCENTRATION

Figure 12. Simulated and measured constituent concentrations used in the water-quality model calibration for nine locations on the Cooper River, S.C., August 23-25, 1993. 

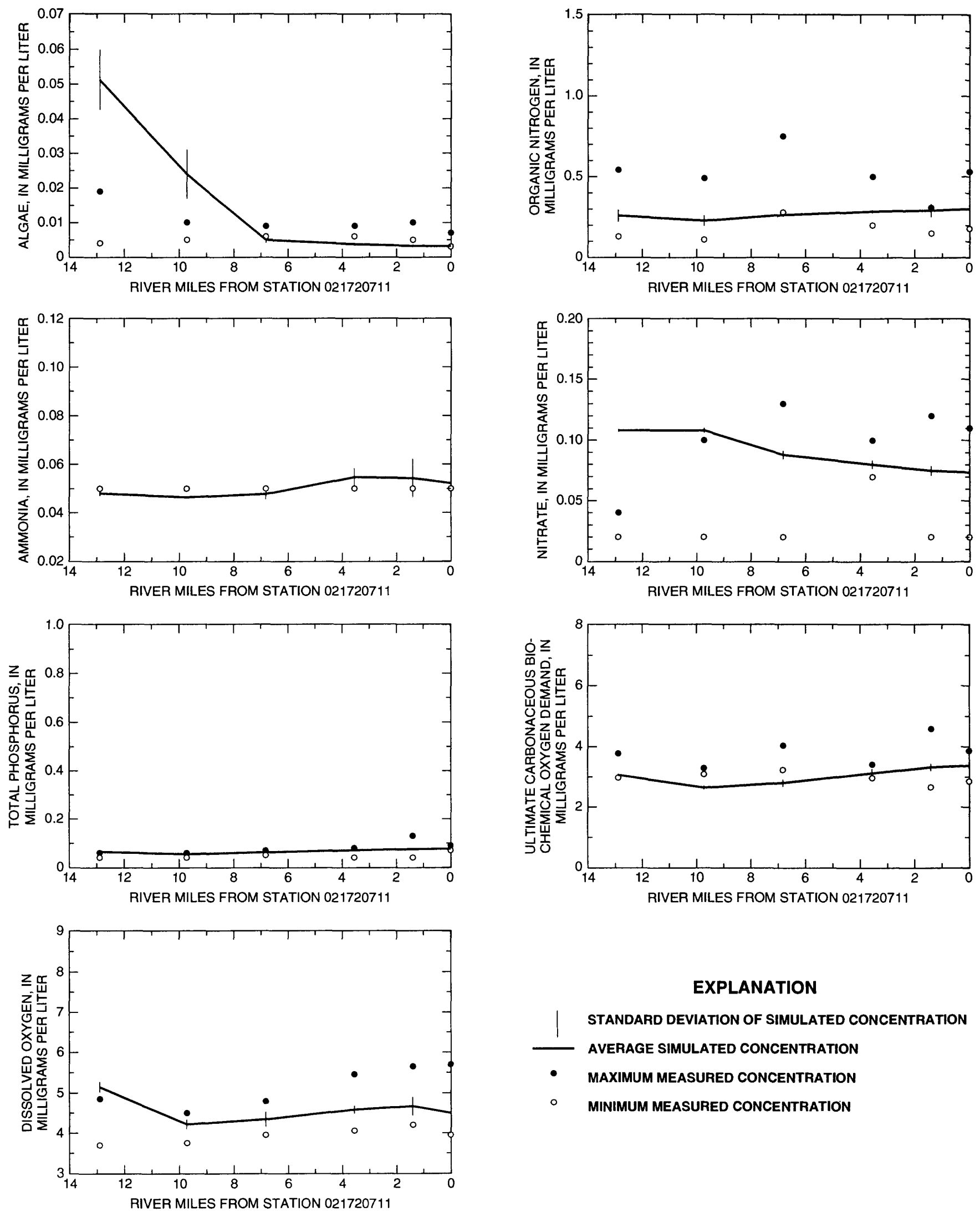

\section{EXPLANATION} STANDARD DEVIATION OF SIMULATED CONCENTRATION AVERAGE SIMULATED CONCENTRATION

- MAXIMUM MEASURED CONCENTRATION - MINIMUM MEASURED CONCENTRATION

Figure 13. Simulated and measured constituent concentrations used in the water-quality model calibration for four locations on the Wando River and two locations on the Cooper River, S.C., August 23-25, 1993. 
readings during the nutrient sampling, the simulated dissolved-oxygen concentrations also were compared with measured dissolved-oxygen concentrations from three gaging stations on the Cooper River (stations 02172050, 02172053, and 021720675) and two stations on the Wando River (stations 021720696 and 021720698) (fig. 4).

There were two significant differences in the methods used for collecting dissolved-oxygen data from these gaging stations as compared to the dissolved-oxygen profiles measured during the nutrient sampling. First, the probes for the gaging stations were set at fixed elevations that did not vary with changes in water level. For stations instrumented with one set of probes, the probes were set at mid-depth of high water. For stations instrumented with two sets of probes, the probes were set approximately one meter from the bottom and one meter below the mean low-water elevation. The values from the two probes were averaged to compute a mean value. The dissolved-oxygen profiles measured during the nutrient sampling were recorded at one meter intervals from the water surface. Second, the gaging stations on the Cooper River were located along the right bank of the river, whereas the dissolvedoxygen profiles measured during the nutrient sampling were measured at mid-channel. For station 021720675 , located just downstream of the confluence of Goose Creek with the Cooper River, the measured dissolved-oxygen concentrations on an outgoing tide were influenced more by the dissolved-oxygen concentrations of Goose Creek than a mid-channel measurement. The gaging stations on the Wando River were attached to bridge piers located near the center channel.

The 7-day simulation from August 21-27, 1993, shows that simulated dissolved-oxygen concentrations were within the range of measured dissolved-oxygen concentrations, but with less variability (fig. 14). The average measured dissolved-oxygen concentration on the Cooper River at station 02172050 (fig. 14a) was 5.9 $\mathrm{mg} / \mathrm{L}$, with a standard deviation of $0.2 \mathrm{mg} / \mathrm{L}$. The model undersimulated the dissolved-oxygen concentrations with an average value of $5.4 \mathrm{mg} / \mathrm{L}$ and a standard deviation of $0.1 \mathrm{mg} / \mathrm{L}$. Farther downstream at station 02172053 (fig. 14b), the average measured concentration was $4.8 \mathrm{mg} / \mathrm{L}$ and a standard deviation of 0.2 $\mathrm{mg} / \mathrm{L}$. The model only slightly oversimulated the dissolved-oxygen concentrations with an average of $4.9 \mathrm{mg} / \mathrm{L}$ and a standard deviation of $0.2 \mathrm{mg} / \mathrm{L}$. At station 021720675 (fig. 14c), the average measured dissolved-oxygen concentration was $5.0 \mathrm{mg} / \mathrm{L}$ with a standard deviation of $0.7 \mathrm{mg} / \mathrm{L}$ as compared to the average simulated dissolved-oxygen concentration of $4.1 \mathrm{mg} / \mathrm{L}$ with a standard deviation of $0.1 \mathrm{mg} / \mathrm{L}$.

On the Wando River, at station 021720696 (fig. $14 \mathrm{~d}$ ), the average measured dissolved-oxygen concentration was $4.6 \mathrm{mg} / \mathrm{L}$ with a standard deviation of 0.6 $\mathrm{mg} / \mathrm{L}$. The average simulated concentration was 5.1 $\mathrm{mg} / \mathrm{L}$ with a standard deviation of $0.1 \mathrm{mg} / \mathrm{L}$. At station 021720698 (fig. 14e), the average measured dissolvedoxygen concentration was $4.3 \mathrm{mg} / \mathrm{L}$ with a standard deviation of $0.6 \mathrm{mg} / \mathrm{L}$ as compared to the average simulated concentration of $4.4 \mathrm{mg} / \mathrm{L}$ with a standard deviation of $0.2 \mathrm{mg} / \mathrm{L}$. This trend also is seen in the longitudinal profiles of the simulated dissolved-oxygen concentrations for the Wando River (fig. 13g), where the average concentrations are nearer the minimum measured concentration in the lower reaches of the system and gradually approach and exceed the maximum concentration farther upstream.

As mentioned previously, more emphasis was placed on the August calibration dataset than on the April-May validation dataset, because the August dataset represents critical warm weather conditions for dissolved-oxygen concentration. For the validation period, 79 percent of the mean simulated dissolvedoxygen concentration meet the criteria ( 93 percent meet the expanded criteria) and the simulated mean values follow the trend of the measured values on the Cooper River (table 6, figs. 15g and 16g). As seen in the calibration simulation, the validation dissolved oxygen simulations on the Wando River show an increasing concentration in the upper reaches of the river that is not as evident in the measured data. The model also is overestimating the increasing algal biomass concentrations in the upper reaches of the Wando River (fig. 16a) and the increasing dissolvedoxygen concentrations in this reach may be due to overestimating oxygen production by photosynthesis.

The mean simulated $C B O D_{u}$ concentration meet the criterion at 79 percent of the stations and the measured and mean simulated $\mathrm{CBOD}_{\mathrm{u}}$ concentrations were generally nearer the minimum measured concentrations than the maximum concentrations (table 6, figs. $15 f$ and $16 f)$. The mean simulated ammonia concentrations meet the criteria at 71 percent of the stations and, as seen in the calibration simulations, the model is responding to a large point source ammonia discharge in the lower Cooper River (table 1) that is not observed in the measured data (table 6 , figs. $15 \mathrm{c}$ and $16 \mathrm{~g}$ ). The 

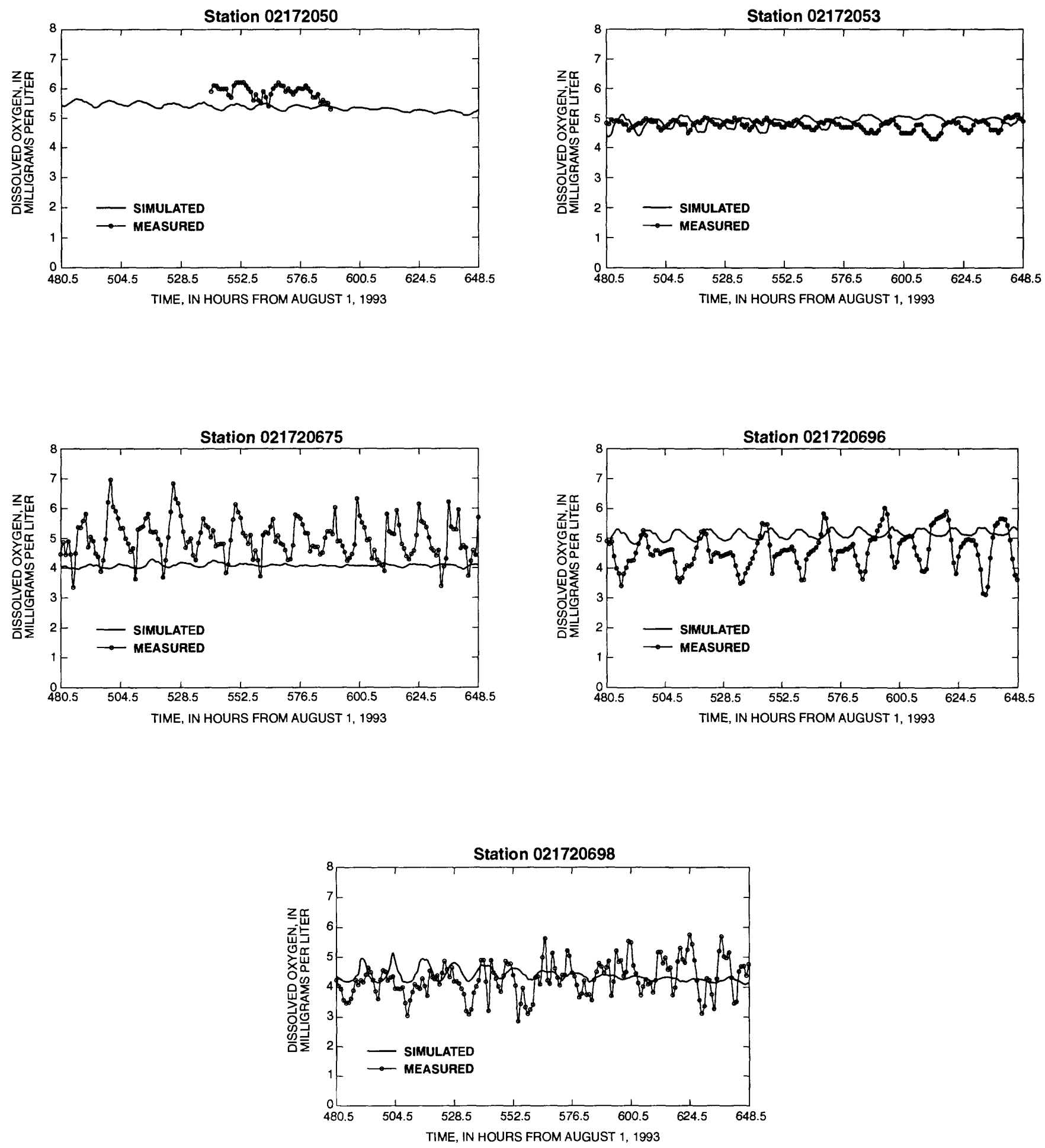

Figure 14. Simulated and measured dissolved-oxygen concentrations used in the water-quality model calibration for three locations on the Cooper River and two locations on the Wando River, S.C., August 21-27, 1993. 

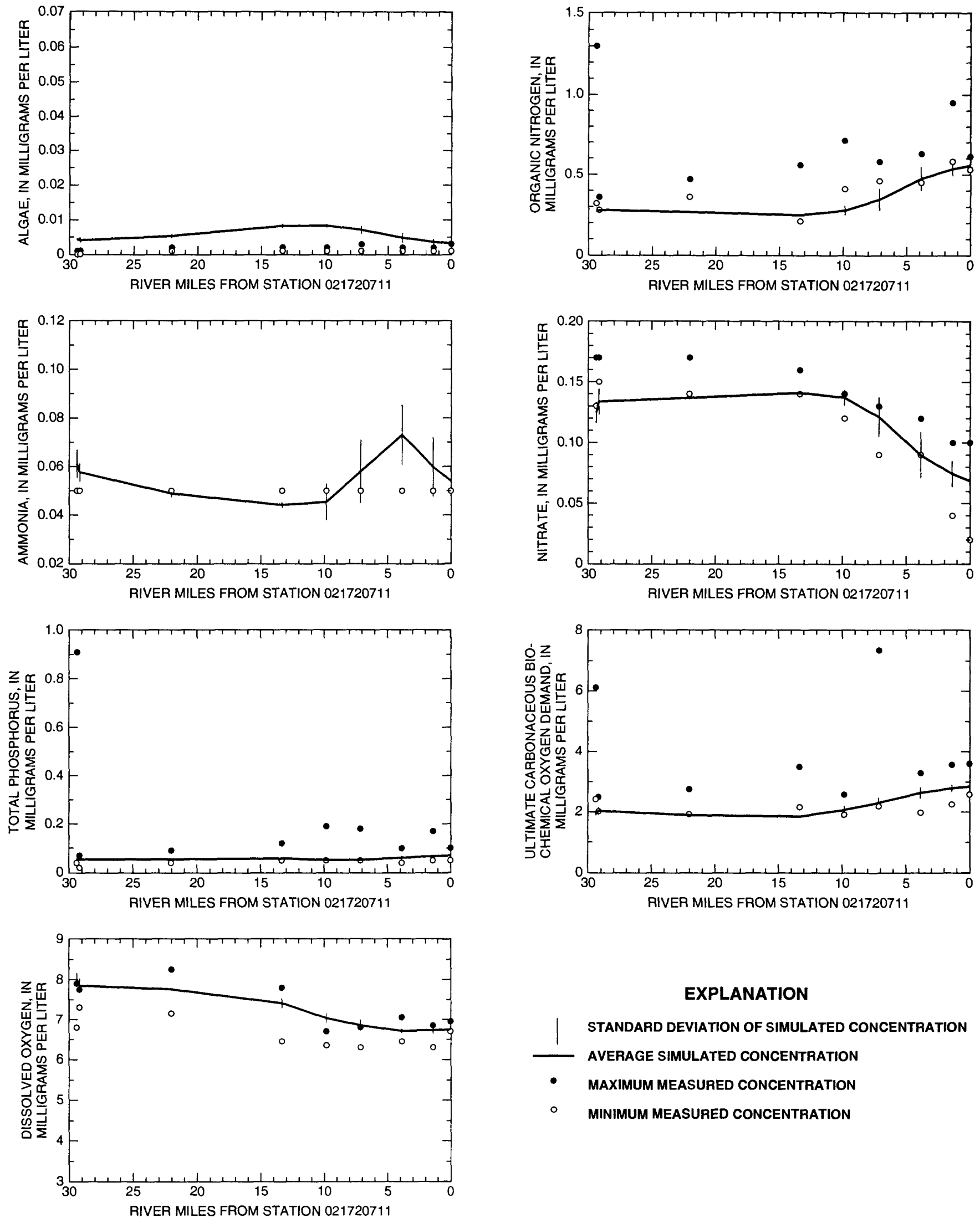

EXPLANATION

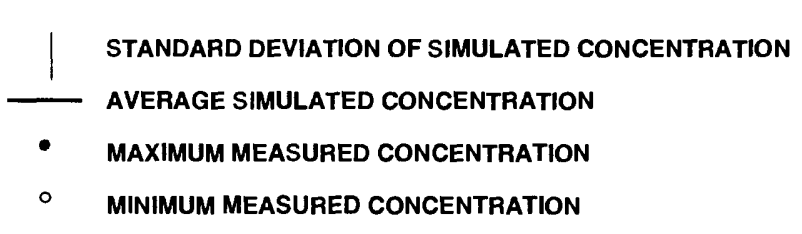

Figure 15. Simulated and measured constituent concentrations used in the water-quality model validation for nine locations on the Cooper River, S.C., May 4-5, 1993. 

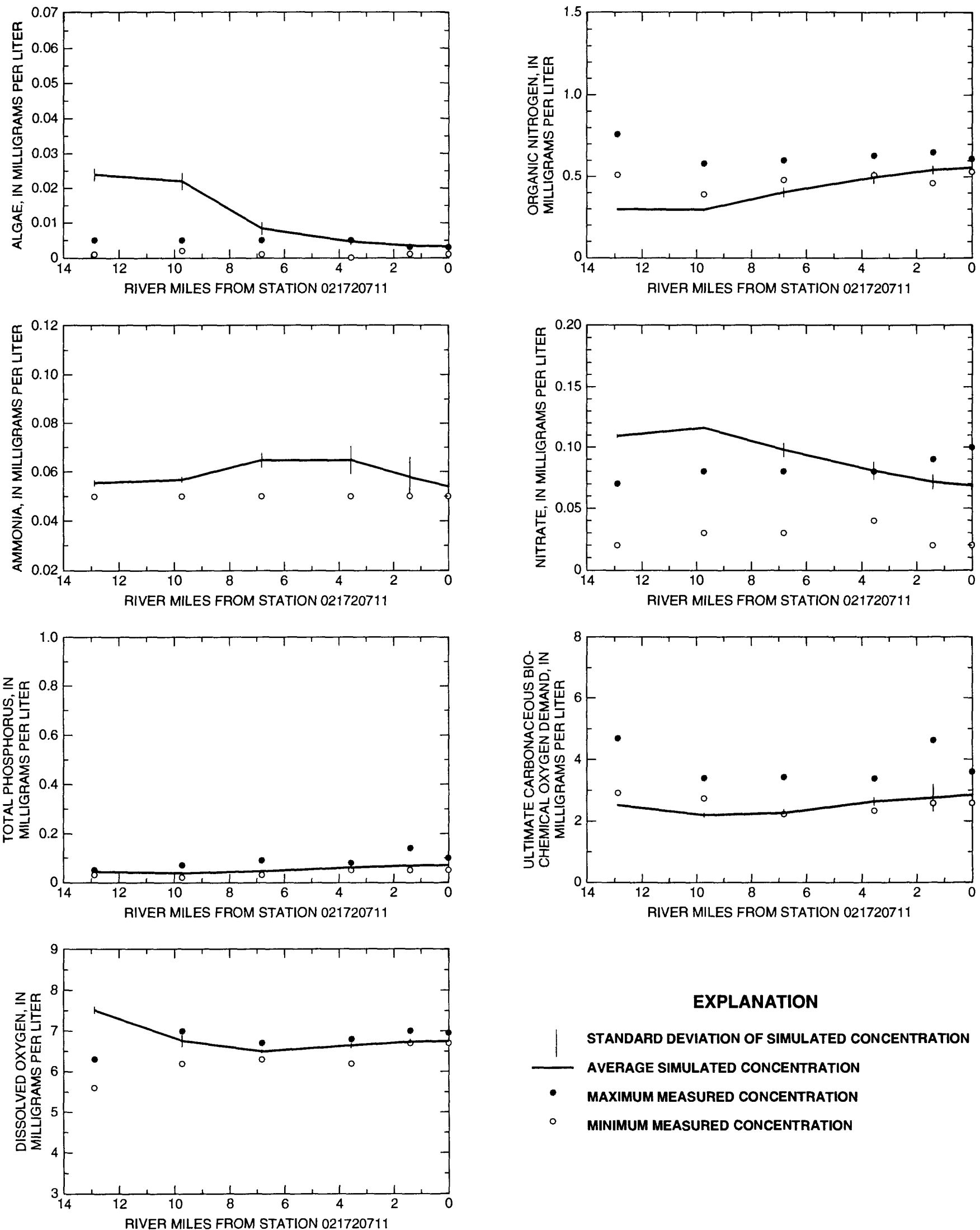

EXPLANATION

STANDARD DEVIATION OF SIMULATED CONCENTRATION AVERAGE SIMULATED CONCENTRATION MAXIMUM MEASURED CONCENTRATION MINIMUM MEASURED CONCENTRATION

Figure 16. Simulated and measured constituent concentrations used in the water-quality model validation for four locations on the Wando River and two locations on the Cooper River, S.C., May 4-5, 1993. 
mean simulated nitrate concentration meet the criteria at 57 percent of the stations and closely follow the trend of the measured data on the Cooper River (table 6, figs. $15 \mathrm{~d}$ and $16 \mathrm{~d}$ ).

The simulated dissolved-oxygen concentrations were compared with continuous dissolved-oxygen concentrations from three gaging stations on the Cooper River and two gaging stations on the Wando River (fig. 17). On the Cooper River the average measured dissolved-oxygen concentration was $7.4 \mathrm{mg} / \mathrm{L}$ with a standard deviation of $0.4 \mathrm{mg} / \mathrm{L}$ at Station 02172050 (fig. 17a). The model oversimulated the dissolvedoxygen concentrations with an average value of 7.9 $\mathrm{mg} / \mathrm{L}$ and a standard deviation of $0.2 \mathrm{mg} / \mathrm{L}$. Farther downstream at station 02172053 (fig. 17b) the average measured concentration was $7.2 \mathrm{mg} / \mathrm{L}$ with a standard deviation of $0.3 \mathrm{mg} / \mathrm{L}$. The model oversimulated the dissolved-oxygen concentrations with an average of $7.3 \mathrm{mg} / \mathrm{L}$ with a standard deviation of $0.2 \mathrm{mg} / \mathrm{L}$. At station 021720675 (fig. 17c), the average dissolved-oxygen concentration was $5.7 \mathrm{mg} / \mathrm{L}$ with a standard deviation of $0.3 \mathrm{mg} / \mathrm{L}$, as compared to the average simulated dissolved-oxygen concentration of $6.2 \mathrm{mg} / \mathrm{L}$ with a standard deviation of $0.1 \mathrm{mg} / \mathrm{L}$. This trend is seen in the longitudinal profiles of simulated dissolvedoxygen concentrations for the Cooper River (fig. 15g), where the average simulated values during the period of the nutrient sampling were either between the minimum and maximum measured concentrations or exceeded the maximum concentration.

On the Wando River, the simulated dissolvedoxygen concentrations were within the range of measured dissolved-oxygen concentrations, but the simulated concentrations did not show the decreasing trend of the measured data (figs. $17 \mathrm{~d}$ and 17e). At station 021720696 (fig. 17d), the average measured dissolvedoxygen concentration was $6.2 \mathrm{mg} / \mathrm{L}$ with a standard deviation of $0.5 \mathrm{mg} / \mathrm{L}$. The average simulated value was $5.7 \mathrm{mg} / \mathrm{L}$ with a standard deviation of $0.1 \mathrm{mg} / \mathrm{L}$. At station 021720698 (fig. 17e), the average measured dissolved-oxygen concentration was $6.8 \mathrm{mg} / \mathrm{L}$ with a standard deviation of $0.4 \mathrm{mg} / \mathrm{L}$, as compared to the average simulated concentration of $6.1 \mathrm{mg} / \mathrm{L}$ with a standard deviation of $0.2 \mathrm{mg} / \mathrm{L}$. This trend also is seen in the longitudinal profiles of the simulated dissolvedoxygen concentrations for the Wando River (fig. 16g), where the average concentrations are near the minimum measured concentration in the lower reaches of the system and gradually approach the maximum concentration farther upstream. This may be due dissolved oxygen produced by the overestimation of the algal biomass concentration in the upper reaches of the Wando River.

Examination of all 14 calibration and validation data locations for each of the seven modeled constituents indicates that the model more accurately simulated constituent concentrations for the Cooper River than for the Wando River. For the two rivers, the model more accurately simulated the constituent concentrations in the lower reaches of the rivers than in the upper reaches. In general, the model undersimulated the variability of the constituent concentrations as compared to the measured variability.

\section{Sensitivity Analysis}

Sensitivity of the water-quality model to changes in model input data was analyzed by evaluating the standard deviation and mean dissolved-oxygen concentrations of the Cooper River downstream from Goose Creek for the 15-day period of August 16-30, 1993. Three groups of model input were evaluated: model input variables including rate constants and settling rates, meteorological input data, and boundary input data of water-quality constituent concentrations. Simulated dissolved-oxygen concentrations from the calibration simulation for station 021720675 were used to compute a base value (table 7) to compare the simulated dissolved-oxygen concentrations for the sensitivity analysis simulation. Test values for model input data were increased by approximately 25 percent while all other inputs were unchanged. Time-dependent inputs to the model, such as the meteorological input data, reaeration rates, and boundary constituent concentrations, were changed for each simulation time step.

A normalized sensitivity index $\left(\mathrm{S}_{\mathrm{ij}}\right)$ was developed to represent the percent change in the output variable resulting from a 1 -percent change in each rate constant or input data (Brown and Barnwell, 1987). The normalized sensitivity index is:

$$
\mathrm{S}_{i j}=\left(\Delta \mathrm{Y}_{\mathrm{j}} / \mathrm{Y}_{\mathrm{j}}\right) /\left(\Delta \mathrm{X}_{\mathrm{i}} / \mathrm{X}_{\mathrm{i}}\right)
$$


where

$\mathrm{S}_{i j}$ is the normalized sensitivity index for output $Y_{j}$ to input $X_{i}$;

$\Delta Y_{j}$ is the change in the output variable;

$Y_{j}$ is the original value of the output variable;

$\Delta X_{i}$ is the change in the input variable; and

$\mathrm{X}_{\mathrm{i}}$ is the original value of the input variable.

Of the model input variables, the dissolved-oxygen concentrations were most sensitive to the reaeration rate (CK2), the oxygen uptake per unit of ammonia oxidized (ALPH5), and the carbonaceous biochemical oxygen demand decay rate (CK1). Of the meteorological input data, the model was most sensitive to the equilibrium temperature values. Of the boundary data of constituent concentrations, the model was sensitive to the input concentrations of dissolved oxygen, water temperature, and BOD. The results of the sensitivity analysis (table 7) are representative for the reach of the model in the vicinity of the Cooper River near Goose Creek (station 021720675) and may not be characteristic of other reaches of the model with different hydraulic and nutrient characteristics.

Table 7. Sensitivity indices for the Branched Lagrangian Transport Model inputs for the Cooper River downstream from Goose Creek, S.C.

[--, no data; $\mathrm{mg} / \mathrm{L}$, milligrams per liter; -, negative $]$

\begin{tabular}{|c|c|c|c|c|}
\hline Model input & Original value & Test value & $\begin{array}{c}\text { Test } \\
\text { concentration } \\
(\mathbf{m g} / \mathbf{L})\end{array}$ & $\begin{array}{l}\text { Sensitivity } \\
\text { index }\end{array}$ \\
\hline Base value $^{1}$ & -- & -- & 4.017 & -- \\
\hline \multicolumn{5}{|c|}{ Model input variables (table 5) } \\
\hline Al & 3.46 & 4.33 & 4.026 & 0.009 \\
\hline ALGSET & .20 & .25 & 4.018 & .001 \\
\hline ALPHAO & 67.0 & 84.0 & 4.017 & .000 \\
\hline ALPHA1 & .08 & .10 & 4.017 & .000 \\
\hline ALPHA2 & .014 & .018 & 4.017 & .000 \\
\hline ALPHA3 & 1.40 & 1.75 & 4.023 & .006 \\
\hline ALPHA4 & 2.15 & 2.69 & 4.010 & -.007 \\
\hline ALPHA5 & 3.43 & 4.29 & 3.789 & -.226 \\
\hline ALPHA6 & 1.14 & 1.43 & 4.010 & -.007 \\
\hline B1 & 1.30 & 1.63 & 4.021 & .004 \\
\hline BET1 & .35 & .44 & 4.004 & -.013 \\
\hline BET2 & 1.60 & 2.00 & 4.017 & .000 \\
\hline BET3 & .06 & .075 & 3.962 & -.055 \\
\hline CK1 & .06 & .075 & 3.817 & -.199 \\
\hline
\end{tabular}


Table 7. Sensitivity indices for the Branched Lagrangian Transport Model inputs for the Cooper River downstream from Goose Creek, S.C.--Continued

[--, no data; $\mathrm{mg} / \mathrm{L}$, milligrams per liter; -, negative]

\begin{tabular}{|c|c|c|c|c|}
\hline Model input & Original value & Test value & $\begin{array}{c}\text { Test } \\
\text { concentration } \\
\text { (mg/L) }\end{array}$ & $\begin{array}{l}\text { Sensitivity } \\
\text { index }\end{array}$ \\
\hline${ }^{2} \mathrm{CK} 2$ & 1.00 & 1.25 & 4.362 & 0.344 \\
\hline CK4 & 6.00 & 7.50 & 3.993 & -.024 \\
\hline CK5 & 60.0 & 75.0 & 3.922 & -.095 \\
\hline CKL & .02 & .025 & 4.017 & .000 \\
\hline $\mathrm{CKN}$ & .26 & .33 & 4.019 & .002 \\
\hline CKP & .04 & .05 & 4.017 & .000 \\
\hline GRO & 2.50 & 3.13 & 4.019 & .002 \\
\hline $\mathrm{NO} 2 \mathrm{~L}$ & .91 & .68 & 3.977 & .039 \\
\hline PN & .08 & .10 & 4.017 & .000 \\
\hline RSPRT & .35 & .44 & 4.019 & .002 \\
\hline SHAD0 & .10 & .125 & 4.018 & .001 \\
\hline SIG2 & 2.00 & 2.50 & 4.017 & .000 \\
\hline SIG3 & .70 & .875 & 4.003 & -.014 \\
\hline SIG6 & 5.00 & 6.25 & 3.977 & -.040 \\
\hline \multicolumn{5}{|c|}{ Meteorological inputs } \\
\hline Equilibrium temperature $^{3}$ & 1.00 & 1.25 & 3.279 & -.735 \\
\hline Solar radiation ${ }^{3}$ & 1.00 & 1.25 & 3.921 & -.096 \\
\hline Wind velocity ${ }^{3}$ & 1.00 & 1.25 & 3.925 & -.092 \\
\hline \multicolumn{5}{|c|}{ Constituent concentration input } \\
\hline Algae biomass ${ }^{3}$ & 1.00 & 1.25 & 3.920 & -.097 \\
\hline Ammonia $^{3}$ & 1.00 & 1.25 & 3.822 & -.194 \\
\hline $\mathrm{BOD}^{3}$ & 1.00 & 1.25 & 3.638 & -.377 \\
\hline Dissolved oxygen $^{3}$ & 1.00 & 1.25 & 4.446 & .427 \\
\hline Dissolved phosphorus ${ }^{3}$ & 1.00 & 1.25 & 3.922 & -.095 \\
\hline Nitrate $^{3}$ & 1.00 & 1.25 & 3.920 & -.097 \\
\hline Organic nitrogen ${ }^{3}$ & 1.00 & 1.25 & 3.834 & -.182 \\
\hline Temperature $^{3}$ & 1.00 & 1.25 & 3.589 & -.426 \\
\hline
\end{tabular}

${ }^{1}$ Simulated mean dissolved-oxygen concentration for the period August 16-30, 1993.

${ }^{2}$ Time-dependent model computed rate; original and test values are multiplicative factors.

${ }^{3}$ Time-dependent model input; original and test values are multiplicative factors. 

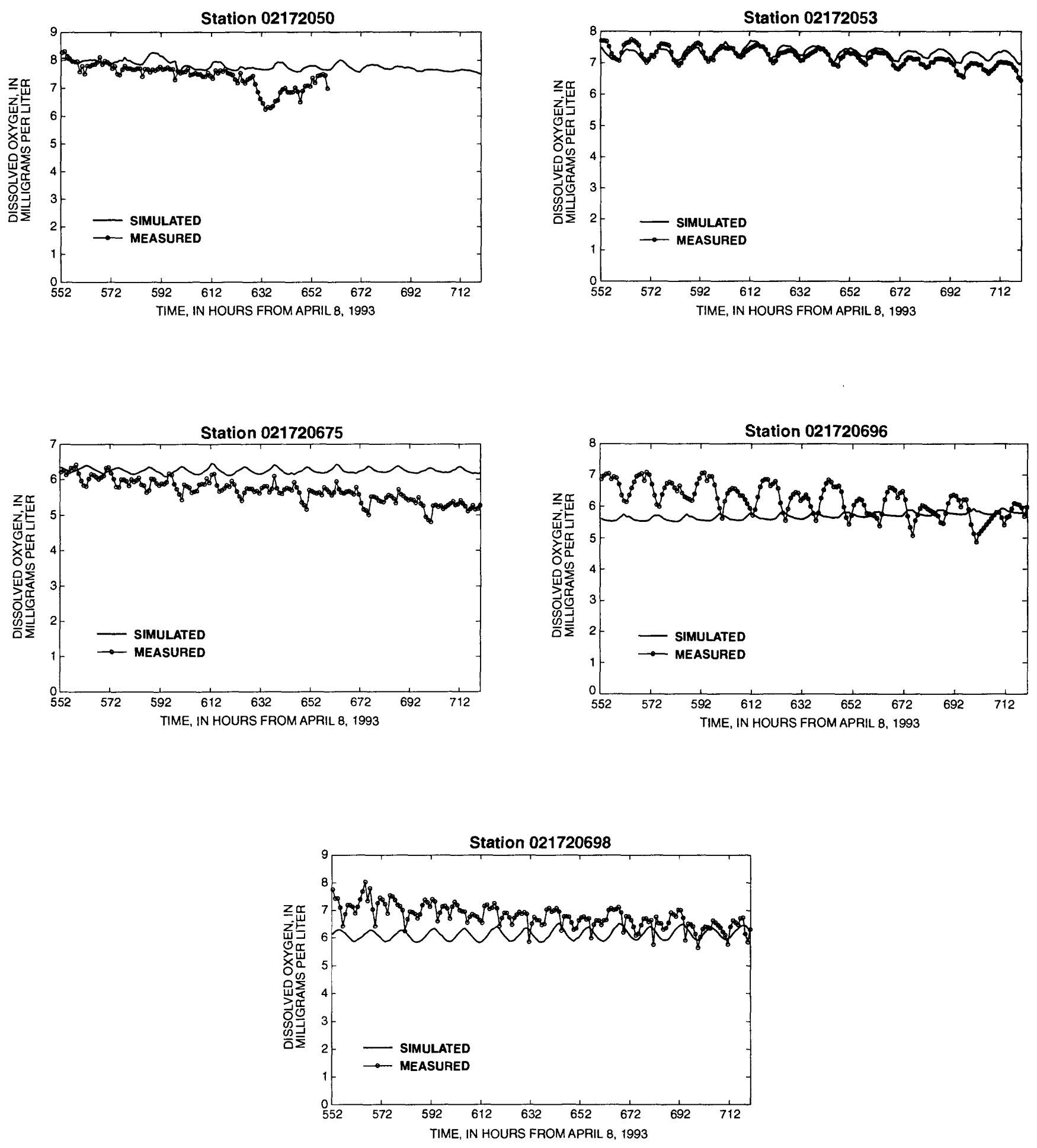

Figure 17. Simulated and measured dissolved-oxygen concentrations used in the water-quality model validation for three locations on the Cooper River and two locations on the Wando River, S.C., May 2-8, 1993. 
WATER-QUALITY MODEL APPLICATIONS

The water-quality model of the Cooper and Wando Rivers was used to simulate various hydrologic and water-quality scenarios to evaluate the effects of the system on the dissolved-oxygen concentrations and, ultimately to gain a better understanding of the system. The August calibration dataset was used for the scenario simulations. Simulated model output was analyzed for 14 sites within the model domain (fig. 18). Four types of scenarios were simulated. The first scenario simulated the release of a conservative tracer from Pinopolis Dam to evaluate the time of travel through the system. The second group of scenarios evaluated the effect of three different flow rates from Pinopolis Dam on the dissolved-oxygen concentrations in the Cooper River. The third group of scenarios evaluated the effect of setting all the dischargers to secondary, advanced secondary, advanced, and reclaimed use levels of wastewater treatment. The fourth group of scenarios evaluated projected point-source loading into the Cooper and Wando Rivers for the years 2000, 2005, 2010 , and 2015.

\section{Time of Travel}

To evaluate the time of travel for a parcel of water in the Cooper River, the BLTM was used to simulate an injection of a conservative tracer at Pinopolis Dam. In the transport model, a conservative constituent with a concentration of $500 \mathrm{ppt}$ was injected at Pinopolis Dam for the first 24 hours of the 30-day calibration flow period. The average flow from Pinopolis Dam during the calibration period was $4,032 \mathrm{ft}^{3} / \mathrm{s}$ with peak discharges greater than $15,000 \mathrm{ft}^{3} / \mathrm{s}$ occurring several times during the 30-day dataset (fig. 19a). Time series of the tracer concentrations were analyzed for 16 locations (14 sites and the Cooper River boundaries) in the model to evaluate the time of travel for the leading edge of the dye (defined as a concentration greater than $0.1 \mathrm{ppt}$ ) and the peak concentration to reach each location (table 8). Flow hydrographs from Pinopolis Dam and the tracer hydrographs for seven sites are shown in figure 19.

Table 8. Time of leading edge, time of peak concentration, and peak concentration for sites on the Cooper and Wando Rivers, S.C.

$[--$, no data]

\begin{tabular}{lccccc}
\hline $\begin{array}{c}\text { Location } \\
\text { (fig. 18) }\end{array}$ & $\begin{array}{c}\text { River miles from } \\
\text { Station 021720711 }\end{array}$ & $\begin{array}{c}\text { River miles from } \\
\text { tracer injection } \\
\text { site }\end{array}$ & $\begin{array}{c}\text { Time of } \\
\text { leading edge } \\
\text { (hours) }\end{array}$ & $\begin{array}{c}\text { Time of } \\
\text { peak concentration } \\
\text { (hours) }\end{array}$ & $\begin{array}{c}\text { Peak concentra- } \\
\text { tion (percent) }\end{array}$ \\
\hline 1021720011 & 47.9 & 0 & -- & -- & 100 \\
Site 1 & 37.9 & 10.0 & 29.5 & 50.5 & 97 \\
Site 2 & 32.4 & 15.5 & 51.5 & 65.5 & 82 \\
Site 3 & 27.9 & 20.0 & 54.5 & 105.5 & 35 \\
Site 4 & 23.9 & 24.0 & 63.5 & 127.5 & 26 \\
Site 5 & 21.0 & 26.9 & 65.5 & 150.5 & 21 \\
Site 6 & 16.9 & 31.0 & 78.5 & 249.5 & 12 \\
Site 7 & 15.3 & 32.6 & 89.5 & 250.5 & 9.3 \\
Site 8 & 12.3 & 35.6 & 112.5 & 326.5 & 5.9 \\
Site 9 & 9.1 & 38.8 & 137.5 & 324.5 & 3.0 \\
Site 10 & 4.2 & 43.7 & 173.5 & 325.5 & 1.3 \\
Site 11 & 8.3 & 52.2 & 329.5 & 532.5 & .2 \\
Site 12 & 5.3 & 49.2 & 229.5 & 349.5 & .3 \\
Site 13 & 2.3 & 46.2 & 212.5 & 374.5 & .5 \\
Site 14 & 1.5 & 46.4 & 222.5 & 423.5 & .4 \\
021720711 & 0.0 & 47.9 & 223.5 & 423.5 & .3 \\
\hline
\end{tabular}

${ }^{1}$ Tracer injection location. 


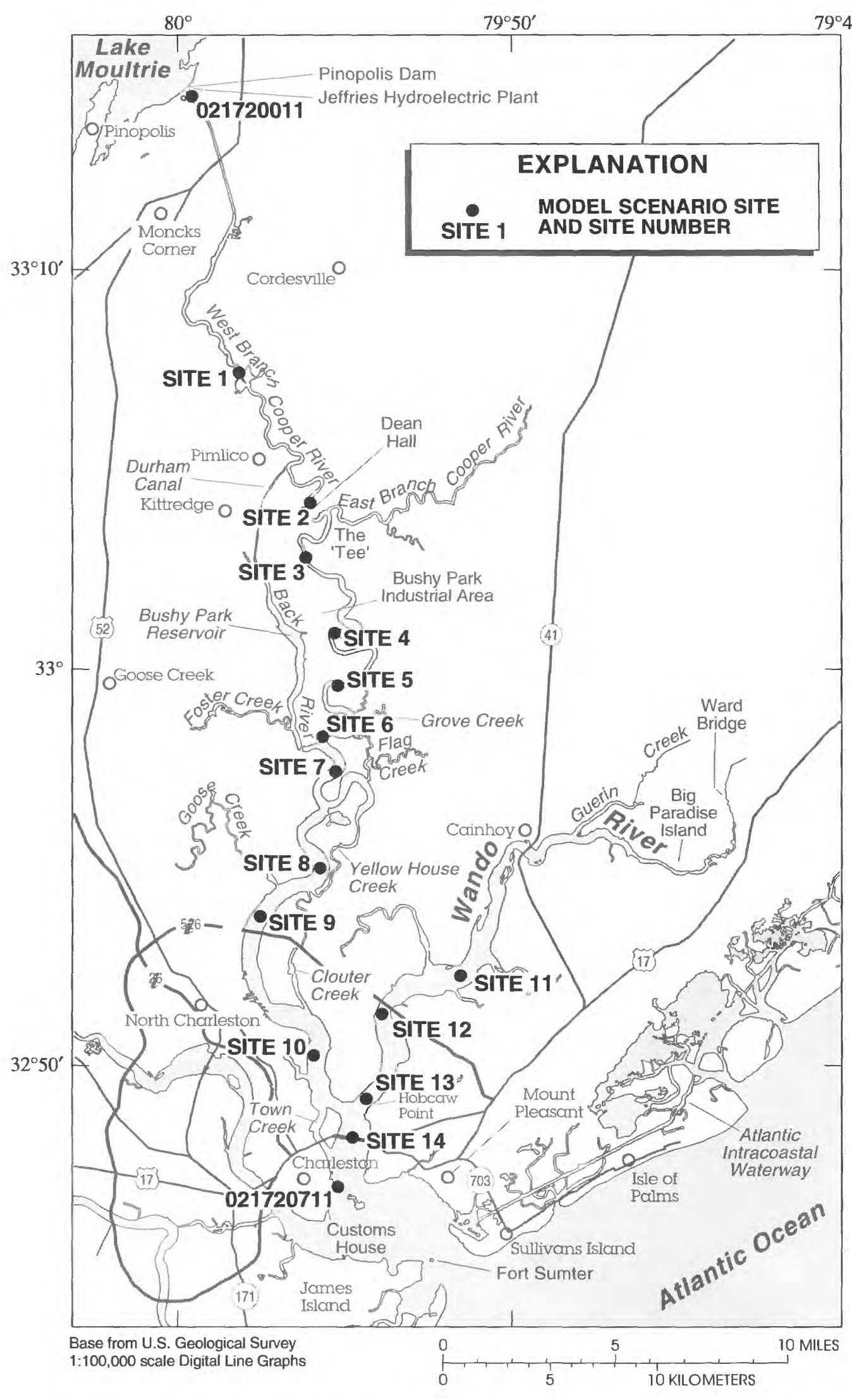

Figure 18. Map showing sites used for model scenarios on the Cooper and Wando Rivers, S.C. 

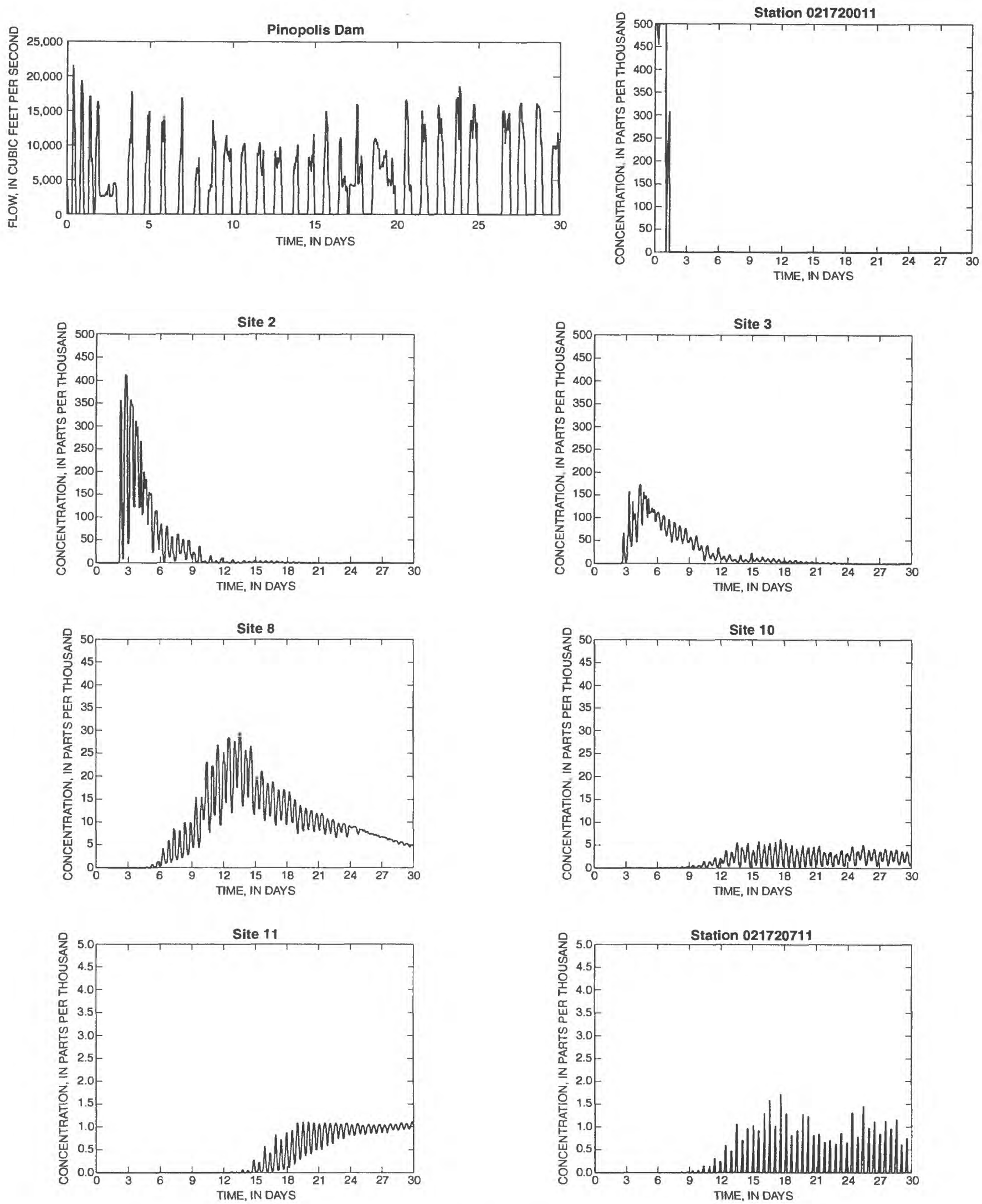

Figure 19. Flow hydrograph for Pinopolis Dam and tracer graphs for six sites on the Cooper River and one site on the Wando River, S.C., for August 1-30, 1993. 
The leading edge of the tracer reached Site 3 (20 mi downstream from the injection site) after 54.5 hours and the peak concentration, 82 percent of the injected concentration, occurred 105.5 hours after the beginning of the simulation (fig.19d). The leading edge of the tracer reached Site 11 on the Wando River (just downstream from Highway 41 and $52.2 \mathrm{mi}$ from the injection point) after 329.5 hours and the peak concentration, 0.2 percent of the injected concentration, occurred after 532.5 hours (fig.19g). It took the leading edge of the tracer 223.5 hours to reach the downstream boundary of the model at Station $021720711,47.9 \mathrm{mi}$ downstream of the injection site, and 423.5 hours for the peak concentration of 0.3 percent of the injected concentration to leave the system (fig.19h).

\section{Flows from Pinopolis Dam}

The flows from Jefferies Hydroelectric Plant at Pinopolis Dam were changed to evaluate the effect of the flows on the dissolved-oxygen concentrations of the Cooper and Wando Rivers. The hydroelectric facility at Pinopolis Dam is operated to generate power during peak electricity demands and to meet mandated minimum flow requirements. The average flow from Pinopolis Dam during the calibration period was 4,032 $\mathrm{ft}^{3} / \mathrm{s}$ with peak discharges greater than $15,000 \mathrm{ft}^{3} / \mathrm{s}$ occurring several times during the 30-day dataset (fig. 19a). Two flow simulations, with an average flow increase or decrease of 50 percent $\left(6,048\right.$ and $2,016 \mathrm{ft}^{3}$ / $\mathrm{s}$, respectively), were compared with the calibration flow period. Each hourly flow value was increased or decreased in order to maintain the variability of the flows from the dam. Although the flows from Pinopolis Dam would have an effect on the other boundaries, especially at stations 02172037 and 02172040 (fig. 4), no other boundary data were adjusted for the increased or decreased flows from the dam.

Twenty-four hour minimum and mean dissolved-oxygen concentrations were computed for 10 sites on the Cooper River and four sites on the Wando River for August 27, 1993. The change in flows had no significant effect on the dissolved-oxygen concentrations on the Wando River. When flows from Pinopolis Dam are decreased, more water from the lower boundary of the model enters the system and effectively increases the residence time of the water in the system. On the Cooper River, a 50 percent decrease in the flows from Pinopolis Dam decreased the mean dissolvedoxygen concentration by an average of 4.2 percent for the 10 sites on the Cooper River (table 4, fig. 20a) as compared to the dissolved-oxygen concentrations during the actual flows from Pinopolis Dam. At Sites 2 and 3, the decrease in the flows had less than a one percent effect on the concentrations. At Site 9, the change in flows decreased the concentration by 8.0 percent. A 50-percent decrease in the flows decreased the 24-hour minimum dissolved-oxygen concentration by an average of 5.2 percent. At Site 3, the 24-hour minimum decreased by 1.0 percent and at Site 10 the $24-$ hour minimum decreased by 11 percent (table 9 , fig. 20b).

A 50-percent increase in the flows from Pinopolis Dam increased the mean 24-hour dissolved-oxygen concentrations for the 10 sites on the Cooper River by an average of 0.9 percent (table 9 , fig. 20a). The concentrations increased by 4.0 percent at Site 7 , whereas the concentrations decreased by 4.6 percent at Site 10 . The increase in the flows from the dam increased the 24-hour minimum dissolved-oxygen concentration by an average of 0.2 percent. At Site 7, the 24-hour minimum concentration increased by 4.4 percent, whereas at Site 10, the 24-hour minimum concentration decreased by 6.6 percent (table 9 , fig. 20b).

The decrease in the dissolved-oxygen concentrations at Sites 9 and 10 with the increase in the flows from Pinopolis Dam may be due to the moving of the dissolved-oxygen profile (dissolved-oxygen sag) downstream and to the water-level boundary used at the downstream station (021720711). The water-levels were measured levels for the calibration period and have not been modified to account for the hypothetical increase in flows from Pinopolis Dam. Additional flows and oxygen-consuming constituents from Pinopolis Dam would be retained in the lower reaches of the Cooper River until the water is flushed through the system with the normal tidal exchange of the lower boundary. 
Table 9. Simulated dissolved-oxygen concentrations for three flow conditions from Pinopolis Dam for 10 sites on the Cooper River, S.C.

[DO, dissolved oxygen; mg/L, milligrams per liter; -, minus]

\begin{tabular}{|c|c|c|c|c|c|c|}
\hline Location & $\begin{array}{c}\text { River } \\
\text { miles from } \\
\text { station } \\
\mathbf{0 2 1 7 2 0 7 1 1}\end{array}$ & $\begin{array}{c}\text { DO under } \\
100 \text { percent } \\
\text { flow condition } \\
\text { (mg/L) }\end{array}$ & $\begin{array}{l}\text { DO under } \\
50 \text { percent } \\
\text { flow condition } \\
\text { ( } \mathrm{mg} / \mathrm{L})\end{array}$ & $\begin{array}{l}\text { Change from } \\
100 \text { percent } \\
\text { flow condition } \\
\text { (percent) }\end{array}$ & $\begin{array}{l}\text { DO under } \\
150 \text { percent } \\
\text { flow } \\
\text { (mg/L) }\end{array}$ & $\begin{array}{l}\text { Change from } \\
100 \text { percent } \\
\text { flow condition } \\
\text { (percent) }\end{array}$ \\
\hline \multicolumn{7}{|c|}{ 24-hour mean values } \\
\hline 1 & 37.9 & 5.15 & 5.01 & -2.7 & 5.16 & 0.2 \\
\hline 2 & 32.4 & 5.35 & 5.30 & -.9 & 5.37 & .4 \\
\hline 3 & 27.9 & 5.17 & 5.13 & -.8 & 5.19 & .4 \\
\hline 4 & 23.9 & 5.05 & 4.96 & -1.8 & 5.10 & 1.0 \\
\hline 5 & 21.0 & 5.00 & 4.86 & -2.8 & 5.07 & 1.4 \\
\hline 6 & 16.9 & 4.75 & 4.52 & -4.8 & 4.89 & 2.9 \\
\hline 7 & 15.3 & 4.50 & 4.22 & -6.2 & 4.68 & 4.0 \\
\hline 8 & 12.3 & 4.19 & 3.90 & -6.9 & 4.35 & 3.8 \\
\hline 9 & 9.1 & 4.02 & 3.70 & -8.0 & 4.00 & -.5 \\
\hline 10 & 4.2 & 4.34 & 4.04 & -6.9 & 4.14 & -4.6 \\
\hline \multicolumn{7}{|c|}{ 24-hour minimum values } \\
\hline 1 & 37.9 & 5.03 & 4.94 & -1.8 & 5.03 & .0 \\
\hline 2 & 32.4 & 5.26 & 5.19 & -1.3 & 5.23 & -.6 \\
\hline 3 & 27.9 & 5.06 & 5.01 & -1.0 & 5.09 & 6 \\
\hline 4 & 23.9 & 5.00 & 4.87 & -2.6 & 5.06 & 1.2 \\
\hline 5 & 21.0 & 4.89 & 4.72 & -3.5 & 4.99 & 2.0 \\
\hline 6 & 16.9 & 4.53 & 4.26 & -6.0 & 4.70 & 3.8 \\
\hline 7 & 15.3 & 4.31 & 4.01 & -7.0 & 4.50 & 4.4 \\
\hline 8 & 12.3 & 4.07 & 3.79 & -6.9 & 4.17 & 2.5 \\
\hline 9 & 9.1 & 3.90 & 3.49 & -10.5 & 3.69 & -5.4 \\
\hline 10 & 4.2 & 3.94 & 3.51 & -10.9 & 3.68 & -6.6 \\
\hline
\end{tabular}



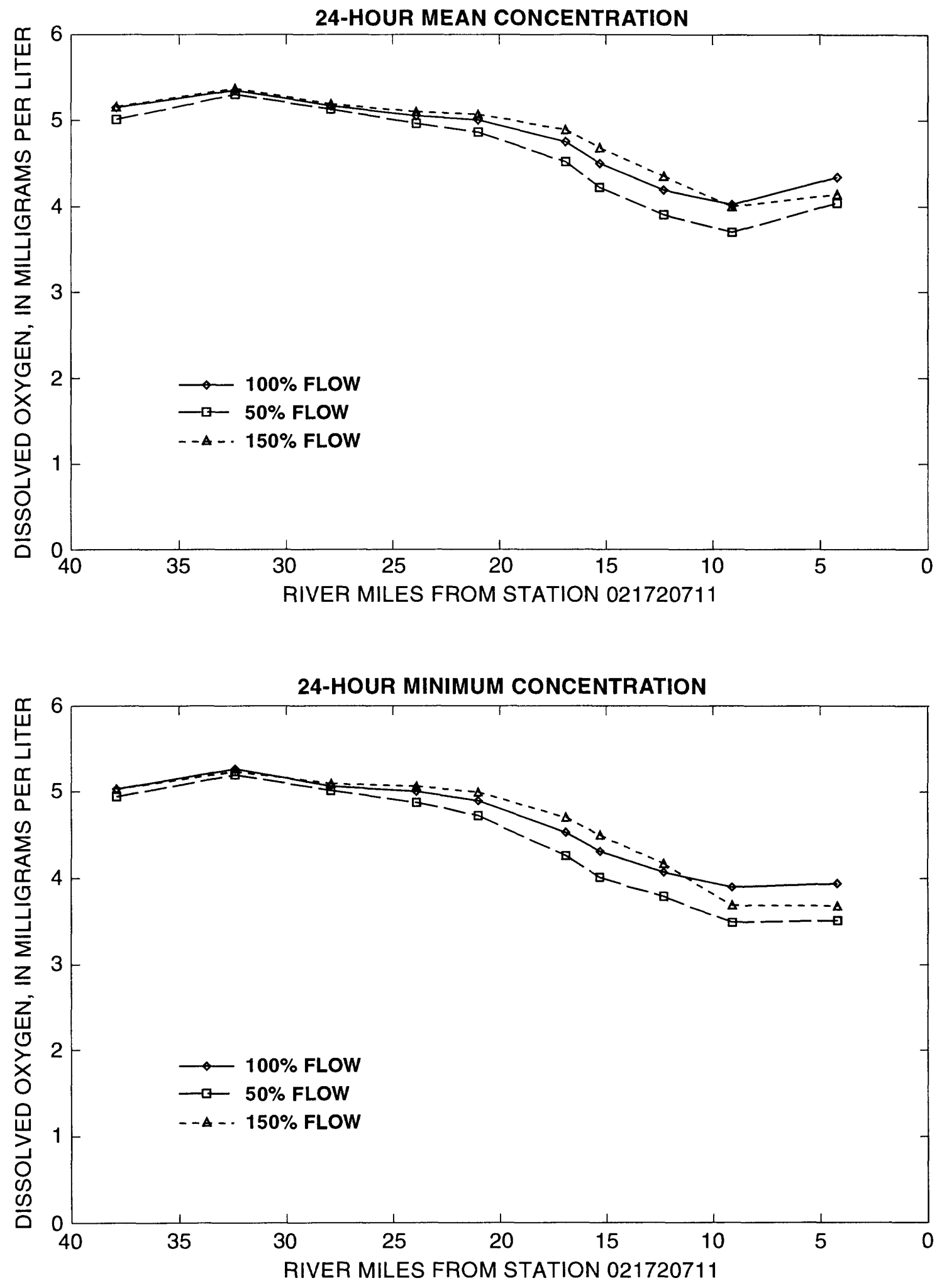

Figure 20. Longitudinal profiles of 24-hour mean and minimum dissolved-oxygen concentrations for three flow conditions on the Cooper River, S.C., August 27, 1993. 


\section{Levels of Wastewater Treatment}

A water-quality model can be utilized by waterresource managers to evaluate the effects of wastewater loads on dissolved-oxygen concentrations, especially in determining the amount of wastewater that a receiving waterbody is able to assimilate. The assimilative capacity of a stream is its ability to absorb a particular pollutant, usually as it relates to an instream water-quality standard. The ability of a stream to assimilate oxygen-consuming substances is a function of many factors including streamflow, water temperature, reaeration, benthic oxygen demands, and channel geometry. In terms of water-resource management, this capacity is expressed as pounds per day $(\mathrm{lb} / \mathrm{d})$ of UOD that can be assimilated without causing a violation of the State water-quality standard for dissolved oxygen.

Wastewater effluent contains many oxygen-consuming constituents, primarily ammonia and biodegradable organic substances. The UOD is the total, theoretical demand for oxygen from carbonaceous and nitrogenous sources. The SCDHEC defines UOD by the equation (South Carolina Department of Health and Environment Control, 1991b):

$$
\begin{gathered}
\mathrm{UOD}=\left(\mathrm{BOD}_{5} \times \mathrm{F}_{\text {ratio }}+\mathrm{NH}_{3}-\mathrm{N} \times 4.57\right) \\
\times \text { Flow } \times 8.34,
\end{gathered}
$$

where

UOD is the ultimate oxygen demand, in pounds per day;

$\mathrm{BOD}_{5}$ is the five-day carbonaceous biochemical oxygen demand, in milligram per liter;

$\mathrm{F}_{\text {ratio }}$ is the conversion factor from $\mathrm{BOD}_{5}$ to ultimate carbonaceous biochemical oxygen demand;

$\mathrm{NH}_{3}-\mathrm{N}$ is the ammonia concentration, in milligrams nitrogen per liter;

4.57 is the stoichiometric ratio of the milligrams of oxygen consumed per milligram of ammonia-nitrogen oxidized;

Flow is wastewater flow, in million gallons per day; and

8.34 is the conversion factor to pounds per day.
The procedure for determining the assimilative capacity of an upland stream is well established. The procedure involves a statistically computed low-flow value that is used in conjunction with a critical water temperature in a simulation model. The results are interpreted in accordance to the State water-quality standards. For many reasons, the procedure for coastal waters is not well established. The dynamic, oscillatory nature of streamflows in estuarine waterbodies makes statistically determined low-flow values very difficult to compute. Critical dissolved-oxygen concentrations may not occur during low-flow periods when estuarine waterbodies are influenced by ocean water with usually higher dissolved-oxygen concentrations. Most water-quality standards are written for upland streams and not for coastal waters, where, in the case of South Carolina, the waters may not meet the dissolved-oxygen concentration standard due to natural conditions. For these waters, effluent releases are permitted only if the instream dissolved-oxygen concentration is minimally affected, which is quantified as less than a $0.1 \mathrm{mg} / \mathrm{L}$ decrease from the natural condition (South Carolina Department of Health and Environment Control, 1993).

The water-quality standard for waterbodies that do not meet the standard due to natural conditions is currently (1997) under review by the SCDHEC. Other issues of concern are critical flow periods and the time interval to use for interpretation of model output for estuarine systems that are dominated by semi-diurnal tidal cycle frequencies of 24.4 hours, 14 days, and 28 days.

Resolving these issues, although necessary for determining the assimilative capacity for coastal waters, are beyond the scope of this report. However, for this report, various point-source loading conditions are compared with a condition where there is no pointsource discharge into the system, described to be a noload condition. The effects of the point-source loading conditions then can be evaluated by comparing the differences in the dissolved-oxygen concentrations for each simulation. The model is used to compare relative differences between various point-source loading conditions rather than to predict the absolute dissolvedoxygen concentration of the system under a particular point-source loading, hydrologic, and meteorologic condition. The modeled absolute value could be in error, but relative differences in the simulated results are more likely to be accurate. 
In this report, various levels of wastewater treatment were evaluated, and 24-hour mean and minimum dissolved-oxygen concentrations (August 27, 1993) were computed for the sites shown in figure 18. The UOD for each simulation was determined to quantify the amount of loading in the system.

The first scenario involved comparing the actual effluent loading to the system during the calibration period to no effluent loading (no-load) and to fully permitted loading conditions. During the calibration period, the point-source loading was at 41 percent of the fully permitted loading to the system. The largest effect of the loading is seen at Site 9, where the 24-hour mean dissolved-oxygen concentration was decreased by 15 percent (fig. 21 , table 10). Under the fully permitted effluent loading condition, the 24-hour mean dissolved-oxygen concentration was decreased between 0.6 and 35 percent as compared to the no effluent loading condition. The 24-hour minimum dissolved-oxygen concentrations followed a similar pattern to the 24-hour mean concentrations. The upper sites (1-5) on the Cooper River experienced small differences due to the additional loading whereas lower sites (6-10) experienced substantial effects.

Table 10. Simulated dissolved-oxygen concentrations for three point-source loading conditions for 10 sites on the Cooper River, S.C.

[DO, dissolved oxygen; $\mathrm{mg} / \mathrm{L}$, milligrams per liter]

\begin{tabular}{|c|c|c|c|c|c|c|}
\hline $\begin{array}{l}\text { Location } \\
\text { (fig. 18) }\end{array}$ & $\begin{array}{c}\text { River } \\
\text { miles } \\
\text { from sta- } \\
\text { tion } \\
021720711\end{array}$ & $\begin{array}{l}\text { Do under } \\
\text { no-load } \\
\text { conditions }{ }^{1} \\
\text { (mg/L) }\end{array}$ & $\begin{array}{c}\text { DO under } \\
\text { actual load } \\
\text { conditions } \\
\text { (mg/L) }\end{array}$ & $\begin{array}{c}\text { Change } \\
\text { from } \\
\text { no-load } \\
\text { condition } \\
\text { (percent) }\end{array}$ & $\begin{array}{l}\text { DO under } \\
\text { fully permitted } \\
\text { conditions }{ }^{3} \\
(\mathrm{mg} / \mathrm{L})\end{array}$ & $\begin{array}{c}\text { Change } \\
\text { from } \\
\text { no-load } \\
\text { condition } \\
\text { (percent) }\end{array}$ \\
\hline \multicolumn{7}{|c|}{ 24-hour mean values } \\
\hline 1 & 37.9 & 5.14 & 5.15 & 0.2 & 5.11 & -0.6 \\
\hline 2 & 32.4 & 5.35 & 5.35 & 0.0 & 5.30 & -0.9 \\
\hline 3 & 27.9 & 5.17 & 5.17 & 0.0 & 5.11 & -1.2 \\
\hline 4 & 23.9 & 5.07 & 5.05 & -0.4 & 4.98 & -1.8 \\
\hline 5 & 21.0 & 5.04 & 5.00 & -0.8 & 4.90 & -2.8 \\
\hline 6 & 16.9 & 4.87 & 4.75 & -2.5 & 4.44 & -8.8 \\
\hline 7 & 15.3 & 4.72 & 4.50 & -4.7 & 3.99 & -15.5 \\
\hline 8 & 12.3 & 4.63 & 4.19 & -9.5 & 3.41 & -26.3 \\
\hline 9 & 9.1 & 4.74 & 4.02 & -15.2 & 3.07 & -35.2 \\
\hline 10 & 4.2 & 4.90 & 4.34 & -11.4 & 3.64 & -25.7 \\
\hline \multicolumn{7}{|c|}{ 24-hour minimum values } \\
\hline 1 & 37.9 & 5.03 & 5.03 & 0.0 & 4.99 & -0.8 \\
\hline 2 & 32.4 & 5.26 & 5.26 & 0.0 & 5.20 & -1.1 \\
\hline 3 & 27.9 & 5.07 & 5.06 & -0.2 & 5.00 & -1.4 \\
\hline 4 & 23.9 & 5.03 & 5.00 & -0.6 & 4.90 & -2.6 \\
\hline 5 & 21.0 & 4.97 & 4.89 & -1.6 & 4.72 & -5.0 \\
\hline 6 & 16.9 & 4.72 & 4.53 & -4.0 & 4.05 & -14.2 \\
\hline 7 & 15.3 & 4.61 & 4.31 & -6.5 & 3.63 & -21.3 \\
\hline 8 & 12.3 & 4.6 & 4.07 & -11.5 & 3.18 & -30.9 \\
\hline 9 & 9.1 & 4.69 & 3.90 & -16.8 & 2.85 & -39.2 \\
\hline 10 & 4.2 & 4.79 & 3.94 & -17.7 & 2.89 & -39.7 \\
\hline
\end{tabular}

1 Ultimate oxygen demand for no-load condition is 0 pounds per day.

${ }^{2}$ Ultimate oxygen demand for actual loading condition is 98,800 pounds per day.

3 Ultimate oxygen demand for fully permitted loading condition is 242,000 pounds per day. 

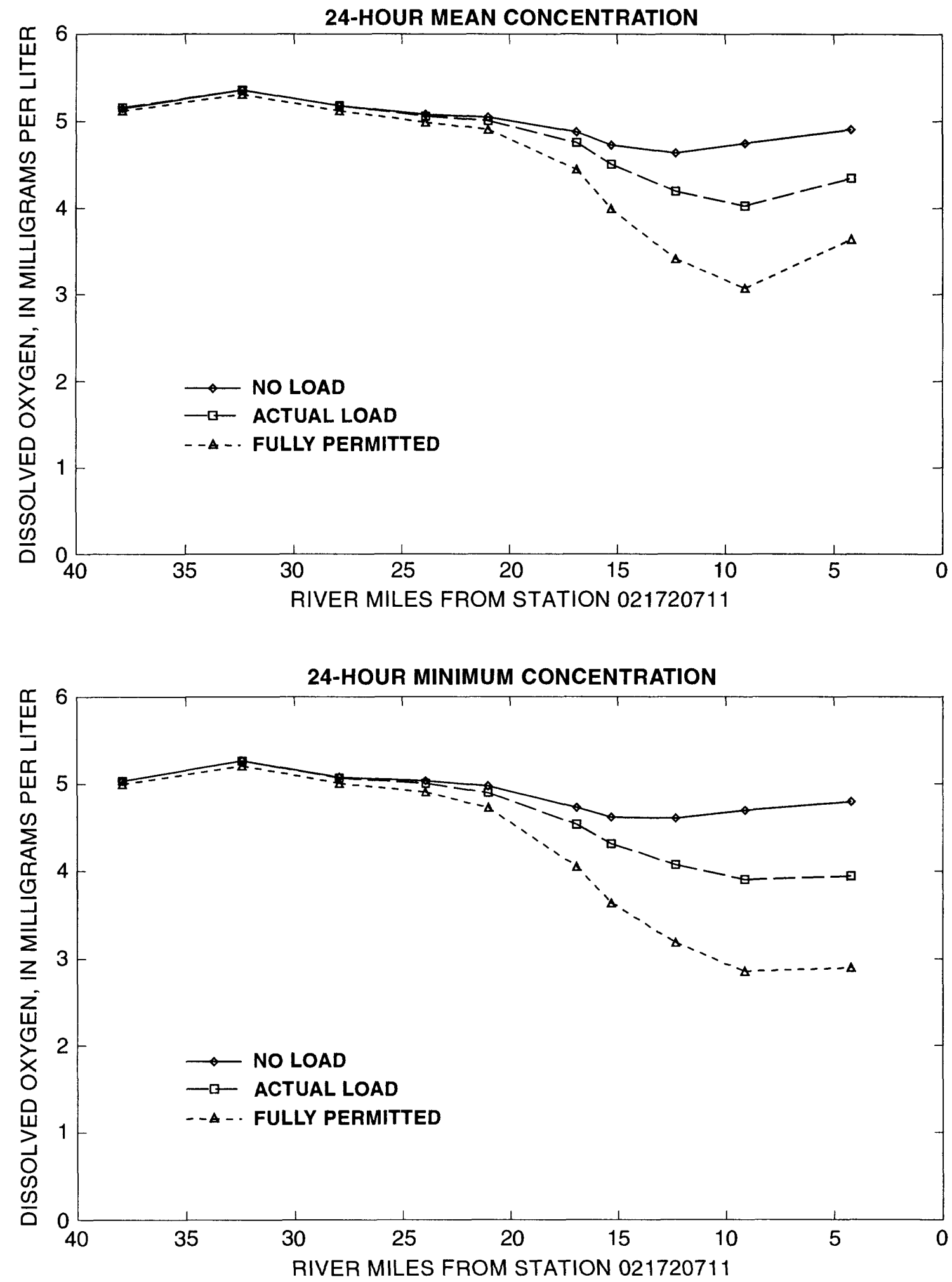

Figure 21. Longitudinal profiles of 24-hour mean and minimum dissolved-oxygen concentrations for three point-source loading conditions on the Cooper River, S.C., August 27, 1993. 
Effluent standards set the level of treatment for municipal and industrial wastewater discharges. Historically, there were three levels of wastewater treatment: primary, secondary, and advanced treatment. With the advancements in wastewater-treatment technology, additional levels of treatment are now widely used and point-source dischargers are better able to process wastewater to lower BOD and ammonia concentrations. These treatment levels now include secondary, advanced secondary, advanced, and reclaimed use.

The dischargers to the Cooper and Wando Rivers are permitted at various levels of effluent treatment. Four scenarios were simulated by setting the effluent concentrations to minimum levels of wastewater treatment for secondary, advanced secondary, advanced, and reclaimed treatment levels. Point-source concentrations were only changed for dischargers that were below a particular level of treatment. The BOD and ammonia concentrations and UOD for each level of treatment are listed in table 11.

Setting the point-source loadings at a minimum of secondary treatment levels reduces the fully permitted UOD to the system by 65 percent ( 15 percent from the observed loading during the August 1993 calibration period). The longitudinal profile of the dissolvedoxygen concentrations under these reduced UOD con- ditions significantly changes for sites on the lower Cooper River (fig. 22). Comparing the longitudinal profiles of the 24-hour mean and minimum dissolvedoxygen concentrations of the no-load and secondary treatment conditions shows a significant increase in the dissolved-oxygen concentrations of the lower Cooper River. The maximum difference from the no-load condition to the fully permitted condition was 35.2 percent for Site 9. Setting the point-source loading to the secondary treatment levels showed the maximum difference of about 15 percent of the mean concentration for the same site.

Setting the point-source loading to the system at advanced secondary treatment levels reduces 79 percent of the loading to the system from the fully permitted condition. The simulated dissolved-oxygen concentrations are lowered by a maximum of 11.2 percent from the no-load condition at Site 8 . Setting the point-source loading to the system at advanced treatment limits represents a 92 percent reduction to the system, and the simulated dissolved-oxygen concentrations are lowered by a maximum of 4.8 percent. Setting the point-source loading to the system at reclaimed-use treatment limits reduces 96 percent of the loading, and the simulated dissolved-oxygen concentrations are lowered by a maximum of 2.7 percent (table 12).

Table 11. Biochemical oxygen demand, ammonia-nitrogen, and dissolved-oxygen concentrations, and ultimate oxygen demand for four wastewater-treatment levels

$\left[\mathrm{BOD}_{5}, 5\right.$-day biochemical oxygen demand; mg/L, milligrams per liter; UOD, ultimate oxygen demand; lb/d, pounds per day]

\begin{tabular}{lcccc}
\hline \multicolumn{1}{c}{ Treatment level } & $\begin{array}{c}\text { BOD5 } \\
(\mathbf{m g} / \mathbf{L})\end{array}$ & $\begin{array}{c}\text { Ammonia-nitrogen } \\
(\mathbf{m g} / \mathbf{L})\end{array}$ & $\begin{array}{c}\text { Dissolved oxygen } \\
(\mathbf{m g} / \mathbf{L})\end{array}$ & $\begin{array}{c}\text { UOD } \\
(\mathbf{l b} / \mathbf{d})\end{array}$ \\
\hline Secondary & 30 & 20 & 1 & 84,300 \\
Advanced secondary & 20 & 10 & 2 & 51,600 \\
Advanced & 10 & 2 & 6 & 20,200 \\
Reclaimed use & 5 & .5 & 6 & 9,210 \\
\hline
\end{tabular}



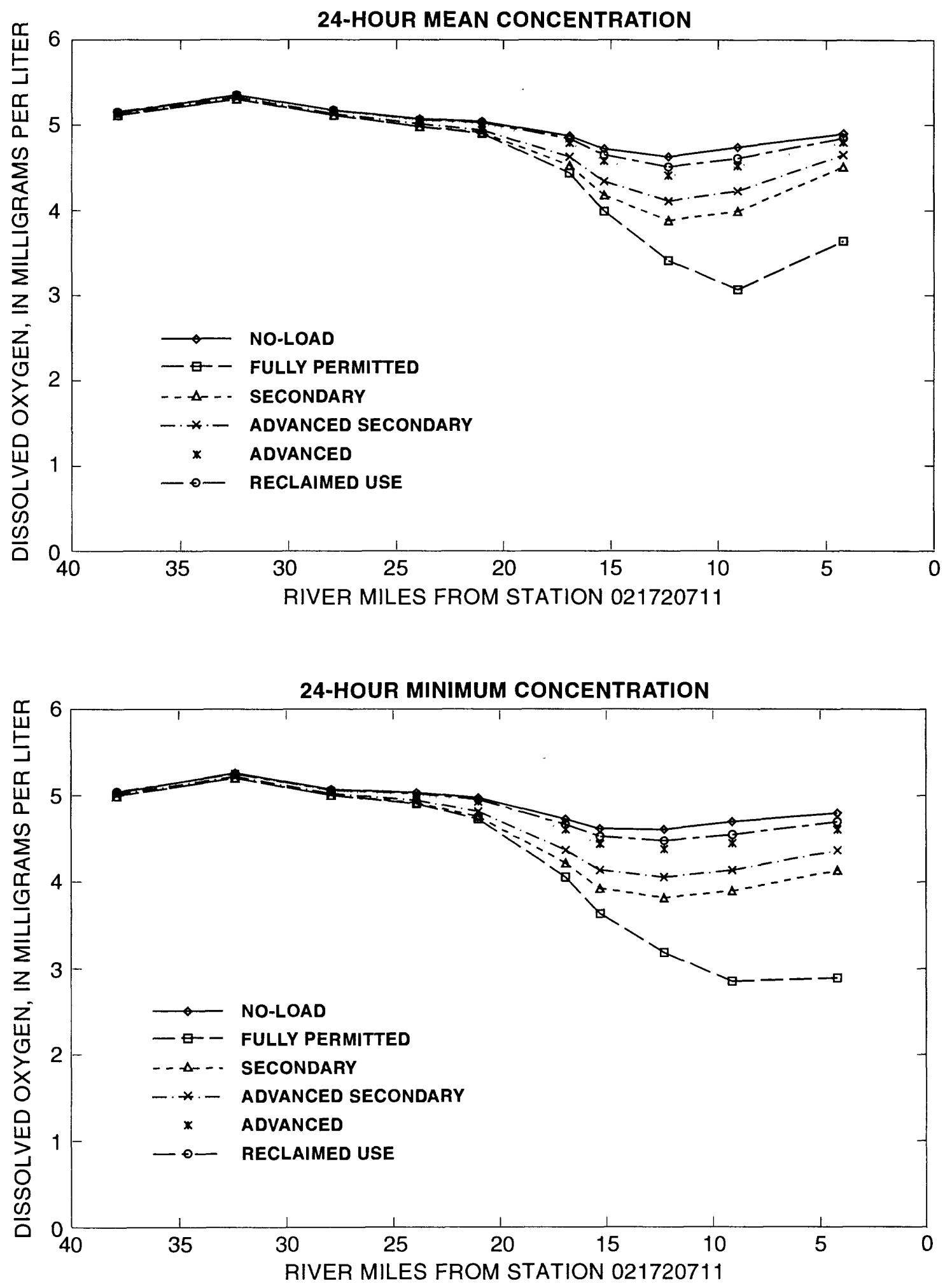

Figure 22. Longitudinal profiles of 24-hour mean and minimum dissolved-oxygen concentrations for six point-source loading conditions on the Cooper River, S.C., August 27, 1993. 


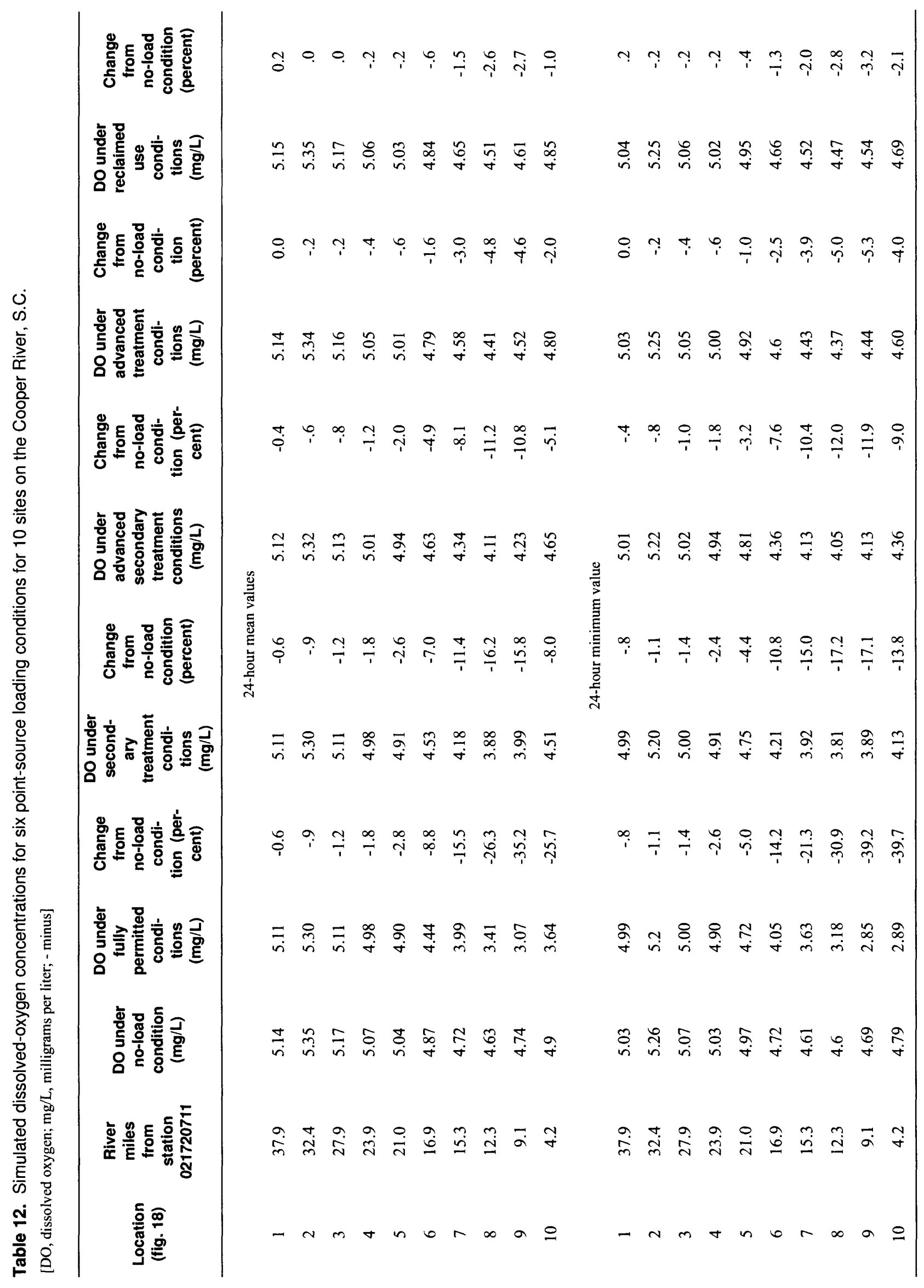




\section{Future Point-Source Loading}

The Charleston Harbor Project solicited the point-source dischargers for their loading needs for the years $2000,2005,2010$, and 2015. The projected point-source discharge loadings were simulated to evaluate the effect on the dissolved-oxygen concentrations. Those that responded represented 73 percent of the UOD under fully permitted conditions. Those that did not respond (representing 27 percent of the UOD) were kept at their currently permitted loading rates.

The projected loadings for the year 2000 represented a 43 percent decrease in the total loading to the Cooper and Wando Rivers. [The large reduction in the total loading to the system is due to a negotiated reduction in the ammonia concentration for one discharger that will take effect in the year 2000 (N.R. Sullins., South Carolina Department of Health and Environmental Control, oral and electronic communications, 1997).] The maximum difference from the noload condition is 25.3 percent at Site 9 , as compared to a difference of 35.2 percent for the fully permitted 1997 condition (table 13, fig. 23). The projected loadings for the year 2005 represent a 40 percent decrease in the loading to the system from the fully permitted 1997 conditions. The 24-hour mean and minimum dissolved-oxygen concentrations are 9.7 to 28.3 percent lower than those of the no-load condition to the system for the lower 5 sites on the Cooper River. The projected loading for the year 2010 is a decrease of 32 percent of the fully permitted loads of 1997 . The loadings for 2010 decreased the 24-hour mean and minimum dissolved-oxygen concentrations between 0.6 and 31.6 percent from the no-load condition. The projected loading for the year 2015 is a decrease of 30 percent of the fully permitted loads of 1997 . The loadings for the year 2015 decreased the 24-hour mean and minimum dissolved-oxygen concentrations between 0.6 and 33.5 percent from the no-load condition. 


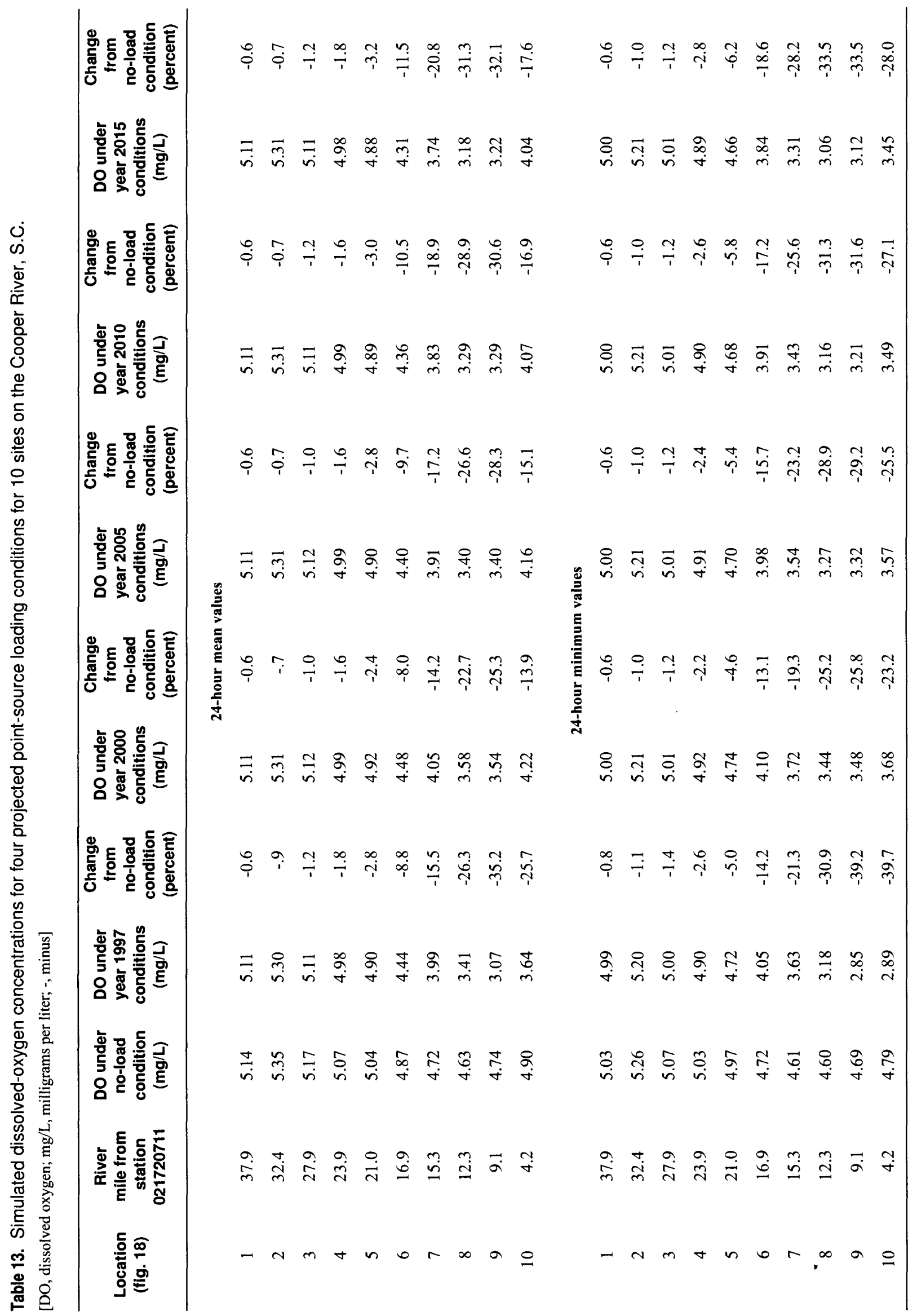



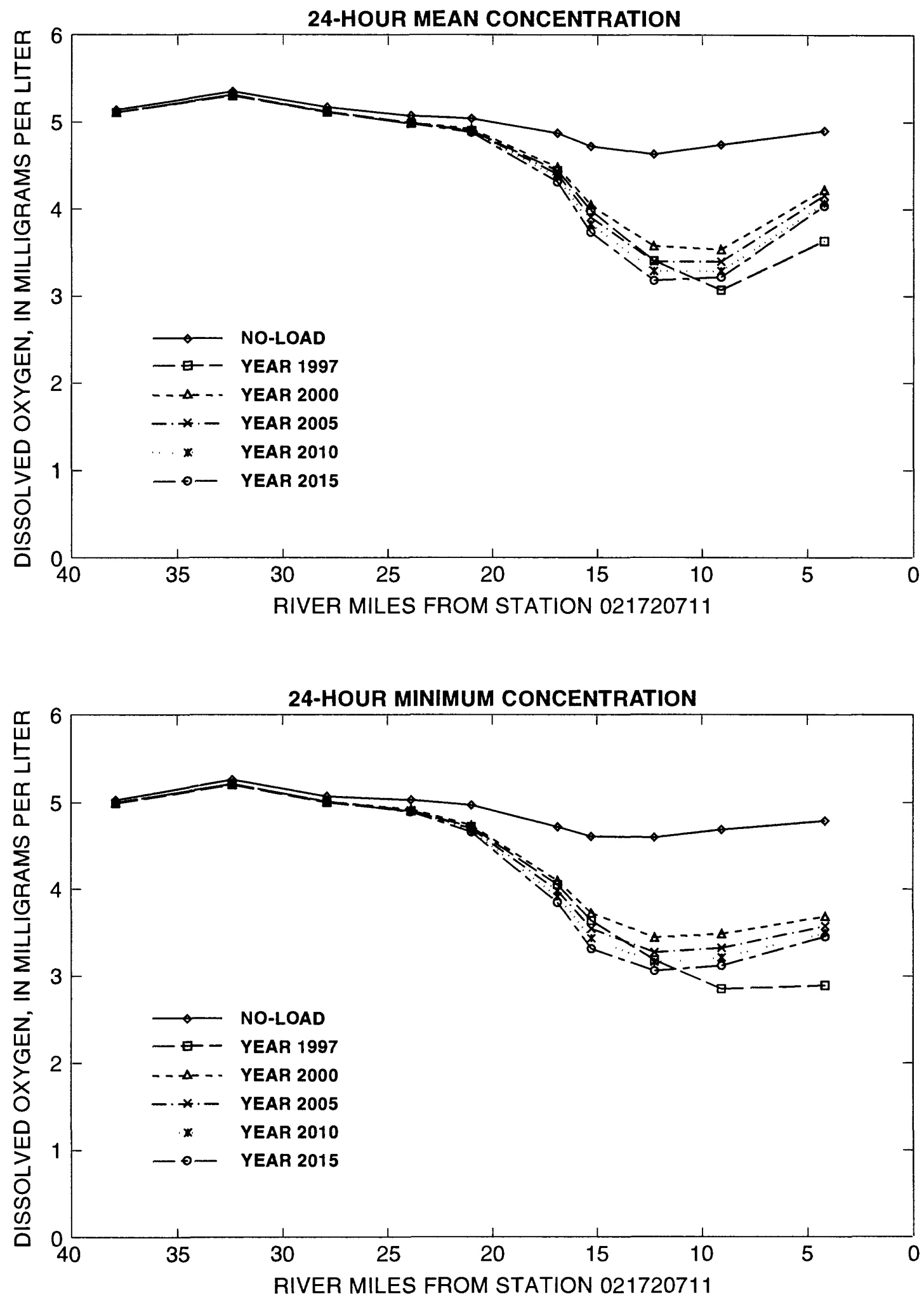

Figure 23. Longitudinal profiles of 24-hour mean and minimum dissolved-oxygen concentrations for four projected point-source loading conditions on the Cooper River, S.C., August 27, 1993. 


\section{SUMMARY}

The U.S. Geological Survey's one-dimensional dynamic-flow model BRANCH and the Branched Lagrangian Transport Model (BLTM) were calibrated and validated for the Cooper and Wando Rivers and their tributaries in the Charleston Harbor area of South Carolina. The study area included the West Branch Cooper River from the Pinopolis Dam to the confluence with the East Branch Cooper River at the Tee, East Branch Cooper River, the Cooper River from the Tee to the Customs House at Charleston Harbor, the Wando River from Ward Bridge to the confluence with the Cooper River, Durham Canal, Flag Creek, Yellow House Creek, Goose Creek, and Guerin Creek. Data used in calibrating and validating the hydraulic and mass-transport models included water levels from four locations on the Cooper River and two locations on the Wando River, tidal-cycle streamflow measurements from five locations on the Wando River, simulated tidal-cycle streamflows from a validated model of the Cooper River at four locations, and calculated salinity concentrations at two locations on the Cooper River and two locations on the Wando River. Data used in calibrating and validating the water-quality model included nutrient and biochemical oxygen demand concentrations collected over five tidal cycles during two sampling surveys at nine locations on the Cooper River and five locations on the Wando River, continuous water temperature data for two locations on the Cooper River and two locations on the Wando River, and continuous dissolved-oxygen concentration data for three locations on the Cooper River and two locations on the Wando River. The streamflow, mass-transport, and water-quality models were calibrated by adjusting model parameters until simulated hydraulic and water-quality values were within the range of measured hydraulic and water-quality data. A sensitivity analysis was performed for all of the model parameters and boundary data.

The water-quality model was used to simulate the dissolved-oxygen concentrations of the Cooper River during various hydrologic and point-source loading conditions. Scenarios included injection of a conservative tracer at Pinopolis Dam to evaluate the time of travel in the system, varying the flows from Pinopolis Dam to evaluate the effect on the dissolved-oxygen concentrations, setting point-source discharges at various levels of wastewater treatment to evaluate the effect on the dissolved-oxygen concentrations, and simulating projected future loading rates by point- source discharges to evaluate the effect on the dissolved-oxygen concentrations.

The time of travel of the system was evaluated by injecting a conservative tracer at the upstream boundary on the Cooper River. A tracer with a concentration of $500 \mathrm{ppt}$ was injected for the first 24 hours of the 30-day calibration period. The leading edge of the tracer (defined as a concentration greater than $0.1 \mathrm{mg}$ / L) reached Site 3 ( $20 \mathrm{mi}$ downstream from the injection site) 2.3 days after the beginning of the simulation and the peak concentration, 35 percent of the injected concentration, reached the site in 4.4 days. The leading edge of the tracer reached Site 9 (38.8 mi downstream from the injection site) 5.7 days after the beginning of the simulation and the peak concentration, 3 percent of the injected concentration, reached the site in 13.5 days. The leading edge of the tracer reached the downstream boundary of the model, $47.9 \mathrm{mi}$ from the injection site, 9.3 days after the beginning of the simulation and the peak concentration, 0.3 percent of the injected concentration, reached the boundary in 17.6 days.

Flows from the Jefferies Hydroelectric Plant at Pinopolis Dam were increased or decreased by 50 percent to evaluate effects on the dissolved-oxygen concentrations of the Cooper River. Evaluation of dissolved-oxygen concentrations at fixed sites on the Cooper River showed that decreasing the flows by 50 percent (from a 30-day average of 4,032 to $2,016 \mathrm{ft}^{3} / \mathrm{s}$ ) decreased the dissolved-oxygen concentration by 8.0 percent or less. Increasing the flows by 50 percent (from a 30-day average of 4,032 to $6,048 \mathrm{ft}^{3} / \mathrm{s}$ ) increased the dissolved-oxygen concentration by 4.0 percent or less at 8 of the 10 sites and decreased the dissolved-oxygen concentration by 4.6 percent or less at three sites.

Various point-source loading conditions to the system were evaluated. The fully permitted 1997 condition decreased the 24-hour mean dissolved-oxygen concentration by 35.2 percent or less from the no-load condition. Setting all the point-source loadings to a minimum of secondary wastewater treatment $(20 \mathrm{mg} / \mathrm{L}$ of ammonia-nitrogen and $30 \mathrm{mg} / \mathrm{L}$ of BOD) decreased the total permitted loading to the system by 65 percent and decreased the 24-hour mean dissolved-oxygen concentrations from the no-load condition by 15.8 percent or less. Setting all the point-source loadings to a minimum of advanced secondary treatment $(10 \mathrm{mg} / \mathrm{L}$ of ammonia-nitrogen and $20 \mathrm{mg} / \mathrm{L}$ of BOD) decreased the total permitted loading to the system by 79 percent and decreased the 24-hour mean dissolved-oxygen 
concentrations from the no-load condition by 11.2 percent or less. Setting all the point-source loadings to a minimum of advanced treatment $(2 \mathrm{mg} / \mathrm{L}$ of ammonianitrogen and $10 \mathrm{mg} / \mathrm{L}$ of BOD) decreased the total permitted loading to the system by 92 percent and decreased the 24-hour mean dissolved-oxygen concentrations from the no-load condition by 4.8 percent or less. Setting all the point-source loadings to a minimum of reclaimed use $(0.5 \mathrm{mg} / \mathrm{L}$ of ammonia-nitrogen and 5 $\mathrm{mg} / \mathrm{L}$ of BOD) decreased the total permitted loading to the system by 96 percent and decreased the 24 -hour mean dissolved-oxygen concentrations from the noload condition by 2.7 percent or less.

Projected point-source loadings for the years $2000,2005,2010$, and 2015 were input into the waterquality model. Decreases of total permitted loading to the system of 43, 40, 32, and 30 percent from the 1997 fully permitted levels are projected for the years 2000 , 2005,2010 , and 2015 , respectively. The projected decreases in 24-hour mean dissolved-oxygen concentrations for the loading conditions of the years 2000 , 2005,2010 , and 2015 over the no-load conditions are $25.3,28.3,30.6$, and 32.1 percent or less, respectively. 


\section{SELECTED REFERENCES}

Ambrose, R.B., Wool, T.A., Connolly, G.A., and Schanz, R.A., 1988, WASP4, a hydrodynamic and water quality model, model theory, user's manual, and programmer's guide: U.S. Environmental Protection Agency, Athens, Georgia, EPA/600/3-87/03.

Bower, D.E., Sanders, C.L., and Conrads, P.A., 1993, Retention time simulation for Bushy Park Reservoir near Charleston, South Carolina: U.S. Geological Survey Water-Resources Investigation Report 93-4070, 47 p.

Bowie, G.L., Mills, W.B., Porcella, D.B., Campbell, C.L., Pagenkopf, J.R., Rupp, G.L., Johnson, K.M., Chan, P.W.H., Gherini, S.A., and Chamberlin, C.E., 1985, Rates, constants, and kinetics formulation in surface water quality modeling, second edition: U.S. Environmental Protection Agency, EPA/600/3-85/040, 455 p.

Brown, L.C., and Barnwell, T.O., Jr., 1987, The enhanced stream water quality models QUAL2E and QUAL2EUNCAS--Documentation and user manual: Athens, Georgia, U.S. Environmental Protection Agency, Environmental Research Laboratory, EPA/600/3-87/007, $189 \mathrm{p}$.

Chestnut, David, 1989, A review of Charleston Harbor water-quality data 1974-1987: South Carolina Department of Health and Environmental Control Technical Report No. 002-89, 124 p.

Conrads, P.A., Cooney, T.W., and Long, K.B., 1997, Hydrologic and water-quality data from selected sites in the Charleston Harbor Estuary and tributary rivers, South Carolina, Water Years 1992-95: U.S. Geological Survey Open-File Report 96-418, 987 p.

Conrads, P.A., and Smith, P.A., 1996, Simulation of water level, streamflow, and mass transport for the Cooper and Wando Rivers near Charleston, South Carolina, 1992-95: U.S. Geological Survey Water-Resources Investigation Report 96-4237, 51 p.

Cooney, T.W., Jones, K.H, Drewes, P.A., Gissendanner, J.W., and Church, B.W., 1996, Water resources data, South Carolina, water year 1995: U.S. Geological Survey Water-Data Report SC-95-1, $634 \mathrm{p}$.

Davis, K. B., Andersen, G.S., and Durel, A.M., 1990, Hydrography, p. 11-46, Chapter III, in A physical and ecological characterization of the Charleston Harbor estuarine system, van Dolah, R.F., Wendt, P. H., and Wenner, E.L. (eds.): Final report to the South Carolina Coastal Council for the Office of Coastal Resources Management under grant NA87AA-D-CZ068, $634 \mathrm{p}$.

Dortch, M.S., Tillman, D.H., and Bunch, B.W., 1992, Modeling water quality of reservoir tailwaters, Technical Report W-92-1, U.S. Army Corps of Engineers Waterways Experiment Station, Vicksburg, Mississippi, $145 \mathrm{p}$.
Drewes, P.A., and Conrads, P.A., 1995, Assimilative capacity of the Waccamaw River and the Atlantic Intracoastal Waterway near Myrtle Beach, South Carolina, 1989-92: U.S. Geological Survey Water-Resources Investigations Report 95-4111, 58 p.

Environmental Laboratory, 1995, CE-QUAL-RIV1: A dynamic, one-dimensional (longitudinal) water-quality model for streams: User's manual, Instruction Report EL-95-2, U.S. Army Corps of Engineers Waterways Experiment Station, Vicksburg, Mississippi, 290 p.

Jobson, H.E., 1977, Thermal model for evaporation from open channels: Congress of the International Association for Hydraulic Research Proceedings, 17th, Baden, Germany, v. 2, p. 95-102.

1980 , Comment on "A new collocation method for the solution of the convection-dominated transport equation," by Pinder, G.E., and Shariro, Allen, 1979, (in Water Resources Research, v. 15, no. 5, p. 1177 -

1182) Water Resources Research, v. 16, no. 6, p. 11351136.

1981, Temperature and the solute-transport simulation in streamflow using a Lagrangian reference frame: U.S. Geological Survey Water-Resources Investigations Report 87-4163, 73 p.

-1985, Simulating unsteady transport of nitrogen, biochemical oxygen demand, and dissolved oxygen in the Chattahoochee River downstream from Atlanta, Georgia: U.S. Geological Survey Water-Supply Paper 2264, $36 \mathrm{p}$.

1997, Enhancements to the Branched Lagrangian Transport Modeling System: U.S. Geological Survey Water-Resources Investigation Report 97-4050, $56 \mathrm{p}$.

Jobson, H.E., and Schoelhamer, D.H., 1987, Users manual for a Branched Lagrangian Transport Model: U.S. Geological Survey Water- Resources Investigation Report 87-4163, $73 \mathrm{p}$.

Kjerfve, Bjorn, 1976, The Santee-Cooper: A study of estuarine manipulations, in M.L. Wiley, ed., Estuarine Processes, v. 1, Academic Press, New York, p. 44-56.

Kjerfve, Bjorn, and Magill, K.E., 1990, Salinity changes in Charleston Harbor 1922-1987: Journal of Waterway, Port, Coastal, and Ocean Engineering 166:153-168.

McKellar, H.N; Douglas, Adrian; Smith, Annette; Munnerlyn, Thaddeus; and Rao, R.P., 1995, Nutrient dynamics and water-quality interactions in the Goose Creek subbasin of the Charleston Harbor estuary. Final report to the South Carolina Department of Health and Environmental Control, Charleston Harbor Project, and the South Carolina Sea Grant Consortium.

Miller, R.L., Bradford, W.L., and Peters, N.E., 1988, Specific conductance--theoretical considerations and application to analytical quality control: U.S. Geological Survey Water-Supply Paper 2311, 16 p. 
National Oceanic and Atmospheric Administration, 1992, Charleston Harbor--Chart 11524, 39th edition: U.S. Department of Commerce, National Ocean Service. - 1993a, Climatological Data South Carolina, April 1993: U.S. Department of Commerce, National Climatic Data Center, v. 96, no. 4 [variously paged]. 1993b, Climatological Data South Carolina, May 1993: U.S. Department of Commerce, National Climatic Data Center, v. 96, no. 5 [variously paged]. 1993c, Climatological Data South Carolina, July 1993: U.S. Department of Commerce, National Climatic Data Center, v. 96, no. 7 [variously paged].

1993d, Climatological Data South Carolina, August 1993: U.S. Department of Commerce, National Climatic Data Center, v. 96, no. 8 [variously paged]. 1995, Tide tables 1995, high and low predictions East Coast of North and South America, Including Greenland: U.S. Department of Commerce, National Ocean Service, 301 p.

Owens, M, Edwards, R.W., and Gibbs, J.W., 1964, Some reaeration studies in streams: International Journal of Air and Water Pollution, v. 8, p. 469-486.

Patterson, G.G., 1983, Effect of the proposed Cooper River rediversion on sedimentation in Charleston Harbor, South Carolina: U.S. Geological Survey WaterResources Investigations Report 83-4198, 65 p.

Schaffranek, R.W., Baltzer, R.A., and Goldberg, D.E., 1981, A model for simulation of flow in singular and interconnected channels: U.S. Geological Survey Techniques of Water-Resource Investigation, book 7, chap. C3, 100 p.

Smith, G.D., 1985, Numerical solution of partial differential equations, finite difference methods, Third Edition: Brunel University, p. 43-45

South Carolina Department of Health and Environmental Control, 1991a, Water quality modeling of the Cooper River: S.C. Department of Health and Environment Control Technical Report 005-91, 30 p.

$1991 \mathrm{~b}$, Agreement on the development of wasteload allocations/total maximum daily loads and NPDES permit limitations, $43 \mathrm{p}$.

1993, Water classifications and standards (Reg. 61 68) and classified waters (Reg. 61-69) for the State of South Carolina, $36 \mathrm{p}$.

1996, Watershed water quality management strategy -- Catawba-Santee Basin: Technical Report No. 002-96, $266 \mathrm{p}$.

South Carolina Land Resources Commission, 1990, SPOT Satellite Image Based Land Use/Land Cover data.

South Carolina Water Resources Commission, 1979, Cooper River controlled low-flow study: S.C. Water Resources Commission, Report No. 131, 352 p.

Teeter, A.M., 1989, Effects of Cooper River rediversion flows on shoaling conditions at Charleston Harbor, Charleston, South Carolina: U.S. Army Corps of Engineers Technical Report HL-89-3, 113 p.
Teeter, A.M., and Pankow, Walter, 1989, Schematic numerical modeling of harbor deepening effects on sedimentation in Charleston, South Carolina: U.S. Army Corps of Engineers Technical Report HL-89-7, 90 p.

Thompson, D.B., 1992, Numerical methods 101-convergence of numerical models, in Jennings, M., and Bhowmik, N.G., eds., Hydraulic engineering: saving a threatened resource--in search of solutions: New York, American Society of Civil Engineers, p. 398-403.

Thomson, N.R., Sykes, J.F., and Lennox, W.C., 1984, A Lagrangian porous media mass transport model: Water Resources Research, v. 20, no. 3, p. 391-403.

U.S. Army Corps of Engineers, 1966, Survey report on Cooper River, S.C.: Appendix A, Supplement 1, Field and laboratory studies, methods and results: Charleston District, S.C., 39 p.

Van Dolah, R.F., Wendt, P. H., and Wenner, E.L., eds., 1990, Physical and ecological characterization of the Charleston Harbor estuarine system, Final Report: South Carolina Coastal Council, Charleston, South Carolina, $634 \mathrm{p}$.

Van Dolah, R.F., and Davis, K.B., 1990, Description of study area, in physical and ecological characterization of the Charleston Harbor estuarine system, Final Report:

South Carolina Coastal Council, Charleston, South Carolina, p. 7.

Weiss, L.A., Schaffranek, R.W., and deVries, M.P., 1994, Flow and chloride transport in the tidal Hudson River, N.Y.: Proceedings 1994 National Hydraulic Engineer Conference, American Society of Civil Engineers, New York, N.Y., p. 1300-1305. 